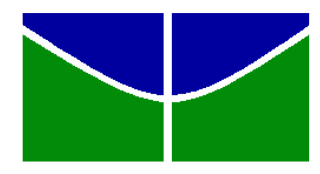

Universidade de Brasília - UnB Instituto de Letras - IL

Departamento de Linguística, Português e Línguas Clássicas - LIP

Programa de Pós-Graduação em Linguística - PPGL

\title{
UMA INVESTIGAÇÃO SOBRE A NATUREZA LOCATIVA DOS PREDICADOS PSICOLÓGICOS NO PORTUGUÊS BRASILEIRO
}

Paula Guedes Baron

Brasília/DF 
Paula Guedes Baron

\title{
UMA INVESTIGAÇÃO SOBRE A NATUREZA LOCATIVA DOS PREDICADOS PSICOLÓGICOS NO PORTUGUÊS BRASILEIRO
}

\begin{abstract}
Dissertação apresentada ao Programa de PósGraduação em Linguística do Departamento de Linguística, Língua Portuguesa e Línguas Clássicas da Universidade de Brasília, como requisito parcial para obtenção do título de Mestre em Linguística. Área de concentração: Teoria e Análise Linguística.
\end{abstract}

Orientadora: Profa. Dra. Rozana Reigota Naves

Brasília/DF 
Ficha catalográfica elaborada automaticamente, com os dados fornecidos pelo(a) autor(a)

BB265i

Baron, Paula Guedes

Uma investigação sobre a natureza locativa dos predicados psicológicos no português brasileiro / Paula Guedes Baron; orientador Rozana Reigota Naves. - Brasilia, 2016.

$125 \mathrm{p}$.

Dissertação (Mestrado - Mestrado em Linguística) Universidade de Brasília, 2016.

1. Predicados psicológicos. 2. Construções perifrásticas. 3. Locativo. 4. Português brasileiro. 5. Verbo leve. I. Naves, Rozana Reigota, orient. II. Título. 


\section{UMA INVESTIGAÇÃO SOBRE A NATUREZA LOCATIVA DOS PREDICADOS PSICOLÓGICOS NO PORTUGUÊS BRASILEIRO}

Dissertação apresentada ao Programa de Pós-Graduação em Linguística do Departamento de Linguística, Português e Línguas Clássicas da Universidade de Brasília, como requisito parcial à obtenção do título de Mestre em Linguística, defendida em 05 de agosto de 2016.

\section{Comissão Examinadora}

Profa. Dra. Rozana Reigota Naves

Universidade de Brasília - Presidente

Prof. Dr. Enrique Huelva Unternbäumen

Universidade de Brasília

Prof. Dr. Marcus Vinicius da Silva Lunguinho

Universidade de Brasília

Profa. Dra. Heloisa Maria Moreira Lima Salles

Universidade de Brasília - Suplente 


\section{AGRADECIMENTOS}

À minha querida orientadora, profa. Rozana Reigota Naves, que sempre foi a grande inspiração para o meu percurso acadêmico na UnB. Com suas aulas, ainda na graduação, tive certeza de que queria seguir o caminho da pesquisa linguística. Obrigada por me proporcionar diferentes experiências ao longo do processo e por sempre transmitir confiança e tranquilidade durante o desenvolvimento deste trabalho.

Aos professores do Programa de Pós-Graduação em Linguística - Eloisa Pilati, Flávia Alves, Helena Guerra, Heloisa Salles, Marcus Lunguinho e Walkíria Praça -, por tantos ensinamentos e pela disponibilidade em sempre responder meus inúmeros questionamentos e inquietações com relação ao estudo da teoria.

Aos professores Marcus Lunguinho e Enrique Huelva, pelos comentários e pelas valiosas sugestões tanto na Avaliação do Projeto de Pesquisa quanto na Comissão Examinadora desta dissertação. Agradeço, também, à professora Heloisa Salles, pela disponibilidade em compor a banca.

Aos amigos que ganhei ao longo do mestrado - Arion (amigo desde a graduação), Bruno, Humberto, Layane e Sarah -, com os quais dividi as alegrias e os desesperos da vida acadêmica.

Às queridas Bete, Bruna e Cris, pela amizade e pela parceria em tantos projetos. Obrigada por tornarem o meu mestrado muito mais significativo e especial!

À Renata. Nossas pesquisas não compartilham o mesmo arcabouço teórico, mas nós compartilhamos uma grande amizade. Obrigada por ser uma amiga de todas e para todas as horas!

À Giovana, pelo cuidado e carinho de sempre.

À Corja - Ana Paula, Edinizis, Isabella, 'Mininu' (Marcos), Nara, Renata, Roberta e Wagner -, por tornar o mestrado muito mais divertido.

Às funcionárias do PPGL, Aline, Ângela e Raquel. Em especial, agradeço aos queridos Armando e Gisele, funcionários do IL, pelas ótimas conversas, pelo carinho e pela constante torcida.

À CAPES, pela bolsa de estudos. 
Aos meus alunos, que me ensinam diariamente a ser professora e, acima de tudo, contribuem, de forma significativa, para meu crescimento pessoal. Obrigada por fazerem os meus dias muito mais felizes!

Aos meus queridos amigos, Diego e Marcos Vinícius, por todo encorajamento, suporte e torcida durante o processo de seleção do mestrado e por ouvirem incansavelmente sobre os verbos psicológicos (desde a graduação!).

À minha família, mãe e Lu. À minha Mãe, por minhas conquistas serem o resultado de todas as suas lutas, de toda a sua coragem e de todo o seu amor. À minha irmã Luísa, por compartilharmos nossas vidas. Amo vocês infinitamente! 


\section{RESUMO}

Nesta dissertação, analisamos as construções perifrásticas dos predicados psicológicos no português brasileiro, com o objetivo de investigar a hipótese de Landau (2010) de que os Experienciadores são cognitivamente locativos e de que os Experienciadores-objeto são gramaticalmente oblíquos. O argumento Experienciador - indivíduo que se encontra em determinado estado psicológico - é mapeado na posição de sujeito em um grupo dos verbos psicológicos, e, em outro, ocupa a posição de objeto. A fim de desenvolver a hipótese de que os Experienciadores são locativos, baseamo-nos em trabalhos realizados na interface semântico-conceitual, que partem das relações semânticas presentes no campo espacial para conceitualizar as estruturas dos demais campos semânticos. A partir da análise das estruturas perifrásticas do português, que são formadas por verbo leve, nominalização (a chamada 'coisa psicológica') e preposição, estabelecemos generalizações descritivas referentes a esses componentes da estrutura, quais sejam: (i) as perífrases dos predicados ExpSuj são formadas pelo verbo leve ter, como em 'João tem amor pela Maria', o qual expressa a semântica de posse presente nesses predicados e, consequentemente, reforça a natureza locativa desses verbos, visto que as noções de posse e de lugar estão interligadas (cf. ARAD, 1998; LAKOFF e JOHNSON, 1999; GONÇALVES et al.; 2010 HUELVA UNTERNBÄUMEN, 2015); (ii) as construções perifrásticas dos predicados ExpObj, que são causativas e implicam uma mudança de estado, constituem-se, majoritariamente, pelos verbos leves causar e dar e pelas preposições 'em', 'a' e 'para', as quais são responsáveis por introduzir o argumento Experienciador, como em 'As fotos causaram/deram preocupação na/para/a Maria'. Propomos que, nas construções perifrásticas, o verbo leve também interfere, semanticamente, na composição dos predicados e, portanto, forma um predicado complexo com a nominalização. Pelo fato de todos os predicados psicológicos serem constituídos por uma eventualidade estativa, adotando a proposta de Viñas-de-Puig (2014), consideramos que os predicados psicológicos possuem uma estrutura básica estativa, que, quando associada a projeções funcionais específicas, passa a configurar uma estrutura de leitura eventiva.

Palavras-chave: Predicados psicológicos. Construções perifrásticas. Verbo leve. Locativo. Português brasileiro. 


\section{ABSTRACT}

In this thesis, we analyze the periphrastic constructions with psychological predicates in Brazilian Portuguese, in order to investigate Landau's (2010) hypothesis that Experiencers are cognitively mental locations and Object Experiencers are grammatically oblique. The Experiencer argument - an individual who is in a certain psychological state - is linked to the subject position in a group of psychological verbs, and occupies the object position in another group of psychological verbs. Looking forward the hypothesis that Experiencers are locative, we have considered works on the semantic-conceptual interface, which departs from the semantic relationships present in the spatial domain to conceptualize structures in other semantic fields. From the analysis of periphrastic structures in Brazilian Portuguese, which are formed by light verb, nominalization (the so-called 'psychological stuff') and preposition, we have established descriptive generalizations regarding these components, namely: (i) The periphrastic structure of SubjExp predicates ('experiencer subject') are formed by the light verb ter 'to have', as in João tem amor pela Maria ('John loves Mary'), which expresses the possession present in these predicates and therefore reinforces the locative nature of SubjExp psych verbs, given that the notions of possession and place are connected (cf. ARAD, 1998; LAKOFF e JOHNSON, 1999; GONÇALVES et al;; 2010 HUELVA UNTERNBÄUMEN, 2015); (ii) the periphrastic constructions of ObjExp predicates, which are causative and imply a change of state, are constituted mainly of the light verbs causar 'cause' and dar 'give', and the prepositions em 'in', a 'to', and para 'for'/'to', which are responsible for introducing the Experiencer argument, as in As fotos causaram/deram preocupação na/para/a Maria ('The photos caused concern in Mary'). We have proposed that in periphrastic constructions the light verb also affects semantically the composition of predicates and therefore forms a complex predicate with the nominalization. Given that all psychological predicates are constituted by a stative eventuality, we adopted the Viñas-de-Puig's (2014) proposal that psychological predicates have a basic stative structure, which attributes an eventive reading to the psychological predicates when associated with specific functional projections.

Keywords: Psychological predicates. Periphrastic constructions. Light verb. Locative. Brasilian Portuguese. 


\section{SUMÁRIO}

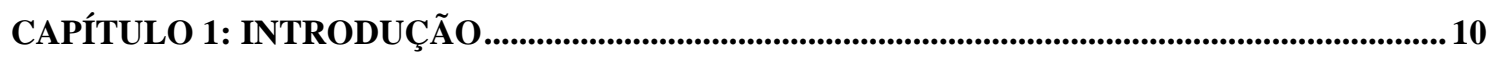

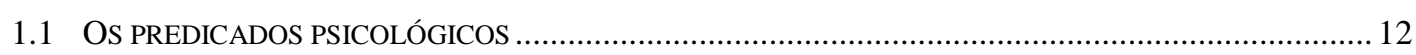

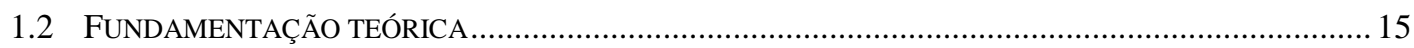

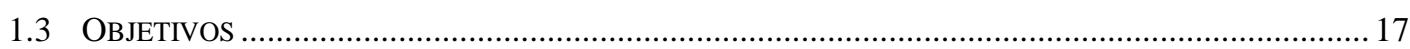

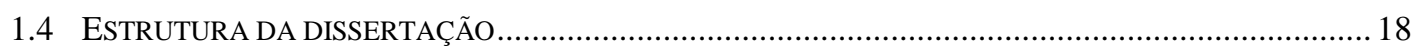

CAPÍTULO 2: A LITERATURA SOBRE OS PREDICADOS PSICOLÓGICOS ............................... 20

2.1 O TRABALHO SEMINAL DE BELLETTI E RIZZI (1988) ............................................................... 20

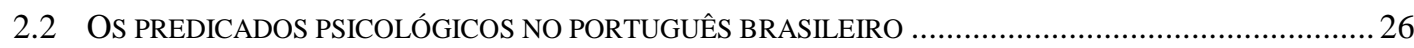

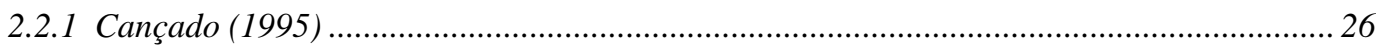

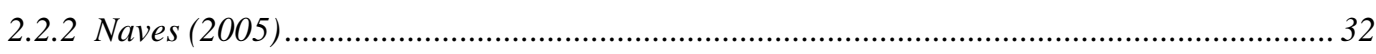

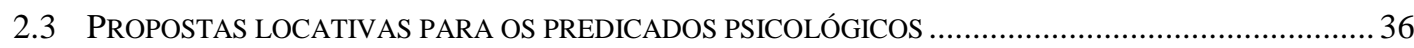

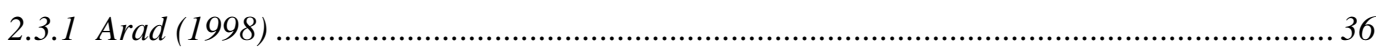

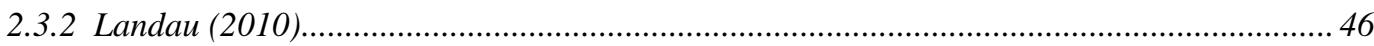

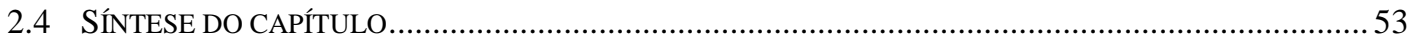

CAPÍTULO 3: O EXPERIENCIADOR COMO LOCUS MENTAL ...............................................55

3.1 A TEORIA SEMÂNTICO-CONCEITUAL DE JACKENDOFF (1983) .................................................. 55

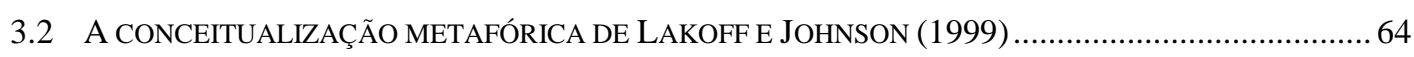

3.3 A ESTRUTURA CONCEITUAL DA CATEGORIA DE TRANSFERÊNCIA DE OBJETO - HUELVA

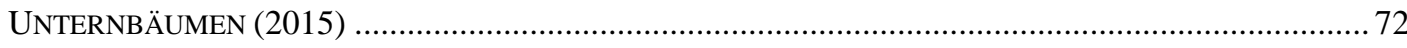

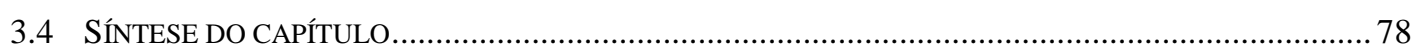

\section{CAPÍTULO 4: AS CONSTRUÇÕES PERIFRÁSTICAS DOS PREDICADOS PSICOLÓGICOS}

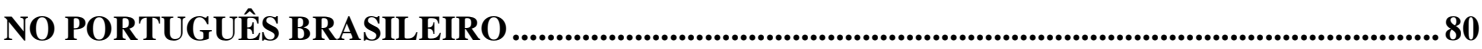

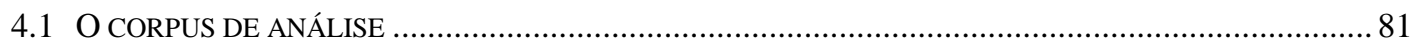

4.1.1 Os predicados Experienciador-Sujeito ............................................................................. 82

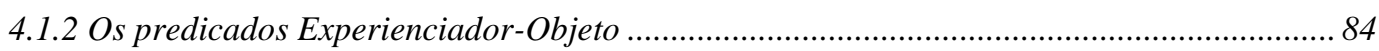

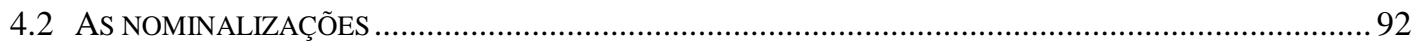

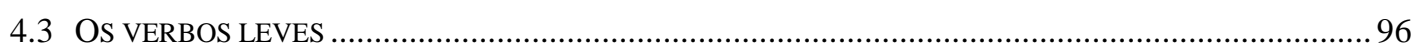

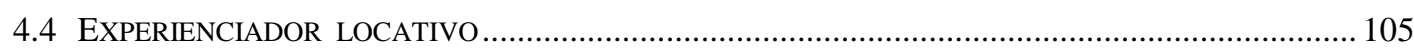

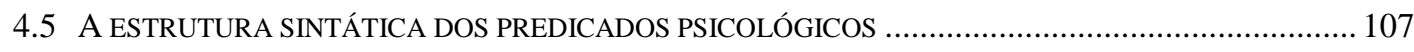

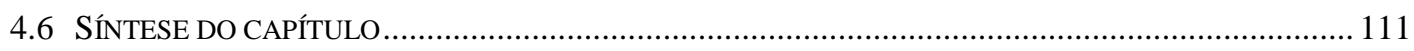

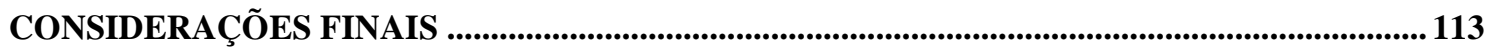

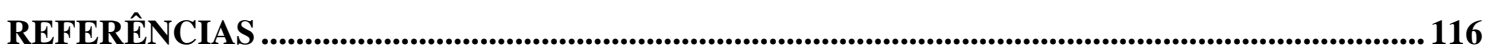

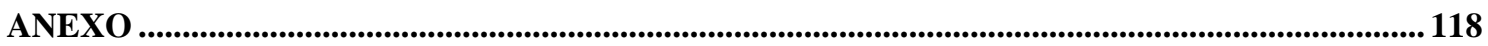




\section{CAPÍTULO 1}

\section{INTRODUÇÃO}

Este trabalho investiga, no âmbito da teoria gerativa, como o pressuposto de que Experienciadores são locus de um estado mental (LANDAU, 2010) se configura para as construções perifrásticas dos predicados psicológicos no português brasileiro. Esses predicados, como detalharemos na próxima seção, se subdividem em duas classes: uma em que o argumento com papel temático de Experienciador encontra-se em posição de sujeito (doravante ExpSuj), como em (1a) e a perífrase em (1b), e outra em que esse argumento encontra-se em posição de objeto (doravante ExpObj), como em (2a) e a perífrase em (2b):

(1) a. João ama Maria.

b. João tem amor pela Maria.

(2) a. O aumento dos impostos estarreceu a população.

b. O aumento dos impostos causou estarrecimento na população.

Consideramos que as perífrases psicológicas (cf. (1b) e (2b)), formadas por um verbo leve e um nome de estado mental, carregam propriedades semânticas equivalentes aos verbos plenos (cf. (1a) e (2a)), o que é empiricamente comprovado em línguas como o francês, que expressam os predicados psicológicos por meio de construções perifrásticas, como em (3):

(3) Jean donne du soucis à Marie.

Jean gives some worry to Marie

'Jean worries Marie.'

'Jean preocupa Maria.'

(BOUCHARD, 1995 apud Landau, 2010, p.16)

O uso das perífrases no português como recorte empírico deste trabalho se justifica pelo fato de que, com esse tipo de construção, a hipótese de Landau (2010), que se refere ao 
fato de a interpretação cognitiva do Experienciador como locativo ser codificada gramaticalmente como um argumento oblíquo nos predicados ExpObj torna-se mais evidente, pois, nas perífrases, o Experienciador é introduzido por uma preposição - como se vê em (2b) e em (3) -, o que não ocorre nas estruturas com verbos plenos, em que esse argumento não é realizado, morfologicamente, como um argumento oblíquo (cf. (2a)).

As construções perifrásticas analisadas neste trabalho configuram-se pela presença de um verbo leve e de um nome cognato ao verbo psicológico. Com relação às nominalizações, acredita-se que elas carregam propriedades relacionadas aos verbos correspondentes, como, por exemplo, o fato de que possuem a mesma estrutura argumental do verbo (OLIVEIRA, 2014). O verbo leve é, tradicionalmente, conceituado como um tipo de verbo que fornece informações gramaticais, como tempo, ao predicado. É importante ressaltar, entretanto, que, mesmo que o seu conteúdo semântico não seja equivalente ao de um verbo pleno, suas propriedades semânticas são relevantes para a interpretação de todo o predicado (SCHER, 2004; GONÇALVES et al., 2010), e, como atestamos neste trabalho, os verbos leves das construções perifrásticas dos predicados psicológicos também são predicados e influenciam na seleção dos argumentos.

Para a análise das construções perifrásticas, partimos da classificação de Cançado (1995) para os verbos psicológicos do português, que distingue três subclasses de verbos ExpObj (como apresentaremos no Capítulo 2), e, ao encontro da proposta da autora, verificamos que os predicados ExpSuj representam uma classe homogênea, com relação à formação das perífrases, que se constituem pelo verbo leve ter (cf. (4)), enquanto os predicados ExpObj dividem-se em subclasses, o que também constatamos na pesquisa sobre as perífrases, em razão de não observarmos um padrão único para os elementos que constituem as construções perifrásticas formadas a partir desse conjunto de verbos, o que reflete diferentes propriedades entre esses predicados. Por exemplo, em uma das subclasses, causar é o verbo leve predominante nas perífrases, enquanto o verbo leve dar é menos produtivo, tendo aparecido esporadicamente no nosso corpus (cf (5)). Já outra subclasse desses predicados utiliza exclusivamente o verbo leve dar nas perífrases que formaram o corpus desta pesquisa (cf. (6)).

(4) As crianças tem respeito / amor / veneração pelos pais.

(5) Os filhos causaram / deram preocupação / aborrecimento nos / para / aos pais. 
(6) O término do trabalho no prazo deu calma / tranquilidade para / ao João.

\subsection{OS PREDICADOS PSICOLÓGICOS}

Os predicados psicológicos são constituídos, impreterivelmente, por um argumento Experienciador, que representa o indivíduo que está em um estado mental/ emocional descrito pelo verbo. Esses predicados expressam algum tipo de sentimento ou emoção, isto é, descrevem estados da mente ou mudanças nos estados da mente (LEVIN, 1993). Com relação ao mapeamento dos seus argumentos, os verbos psicológicos subdividem-se em duas classes: (i) verbos que atribuem o papel- $\theta$ Experienciador apenas ao argumento na posição de sujeito ExpSuj ou classe de temer; e (ii) verbos que atribuem o papel- $\theta$ Experienciador à posição de objeto - ExpObj ou classe de preocupar. ${ }^{1}$

(7) a. O governo teme as manifestações populares.

b. O desempenho dos alunos preocupa a professora.

A classe dos verbos ExpObj diferencia-se, também, da classe ExpSuj por se submeter ao processo de alternância sintática. As sentenças a seguir exemplificam a possibilidade de os verbos da classe de preocupar alternarem (8), em contraponto à classe de temer, que não licencia a alternância, como em (9).

(8) a. As manifestações populares preocupam a presidenta.

b. A presidenta se preocupa com as manifestações populares.

\footnotetext{
(i) a. João escutou os conselhos da mãe.

b. José viu o jogo no estádio.

(ii) a. Ana imaginava uma vida melhor.

b. Maria compreendeu a explicação do professor.

(iii) a. $\underline{\mathrm{O} \text { governo }}$ teme as manifestações populares.

b. O desempenho dos alunos preocupa a professora.
}

${ }^{1}$ Em uma proposta mais ampla para os predicados psicológicos, Croft (1993) propõe que esses verbos dividemse, semanticamente, em três classes: (i) verbos de percepção; (ii) verbos de cognição; e (iii) verbos de emoção/sentimento, sendo esta última, a classe que representa o nosso objeto de estudo neste trabalho. 
(9) a. A presidenta teme as manifestações populares.

b. *As manifestações populares (se) temem com a presidenta.

O processo da alternância sintática refere-se ao fato de um mesmo verbo projetar os seus argumentos em configurações sintáticas distintas. Esse fenômeno ocorre nas mais variadas línguas, que apresentam, entretanto, características variadas e específicas, concernentes ao número e aos tipos de alternâncias possíveis, às classes de predicados que sofrem esse processo e às formas com que os argumentos são mapeados nas estruturas alternantes.

As estruturas sintáticas alternantes dos verbos psicológicos do português do Brasil correspondem às representações esquemáticas a seguir: ${ }^{2}$

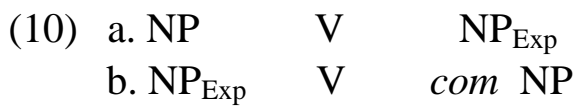

(NAVES, 1998, p.5)

A primeira representação refere-se à estrutura alternante ExpObj, a qual é uma estrutura transitiva simples, que possui um argumento na posição de sujeito e um argumento de papel- $\theta$ Experienciador na posição de objeto (10a). A segunda - ExpSuj - corresponde aos predicados alternantes que envolvem o Experienciador na posição de sujeito e um sintagma preposicional, geralmente introduzido pela preposição com (10b).

O fenômeno da alternância verbal, ao admitir mais de uma estrutura sintática para expressar os argumentos de um dado predicado e, consequentemente, atribuir a mesma grade temática a posições sintáticas distintas, acarreta problemas relativos ao mapeamento dos argumentos e à aquisição de língua. ${ }^{3}$

A questão toda reside no fato de que se supõe que a criança não aprende as relações temáticas para cada item do léxico, devendo, antes, haver princípios que norteiam esse processo e tornam automática a aquisição das grades

\footnotetext{
${ }^{2}$ Na representação em (10), a posição de NP (do inglês, Noun Phrase) também pode ser ocupada por um DP (do inglês, Determiner Phrase).

3 Adotando a ideia de que a GU seria a responsável pelo mapeamento dos argumentos, duas hipóteses foram formuladas na literatura: (i) UTAH, Hipótese da Uniformidade de Atribuição de Papéis- $\theta$ (BAKER, 1988), e (ii) UAH, Hipótese Universal do Alinhamento, PERLMUTTER \& POSTAL, 1984). Naves (1998) ressalta, porém, que, por mais que essas hipóteses sejam interessantes do ponto de vista da aquisição, elas possuem pouco poder explicativo, pois não conseguem elucidar a razão pela qual certos verbos podem projetar duas estruturas sintáticas distintas, enquanto outros não podem.
} 
temáticas pelos falantes. Dado isso, o problema é conciliar o fato empírico da alternância de configuração sintática com o fato teórico de que os falantes não adquirem a grade temática dos itens lexicais caso por caso. Logo, o problema suscitado por verbos psicológicos e pelos verbos alternantes em geral diz respeito não somente à distribuição dos argumentos na estrutura sintática, mas também à questão da aquisição de língua. (NAVES, 1998, p. $5-6)$

O mapeamento - processo de associação de um papel temático a uma função sintática específica - torna-se um problema, no caso dos predicados psicológicos, quando não há a correspondência sistemática do papel temático Experienciador com uma única função sintática, podendo esse argumento ocorrer tanto na posição de sujeito quanto na posição de objeto.

Os predicados psicológicos ExpSuj e os ExpObj também se diferenciam, substancialmente, no que concerne à interpretação semântica que eles possuem. Os verbos ExpSuj recebem uma interpretação estativa, enquanto os verbos ExpObj recebem uma interpretação causativa. Levando em consideração a decomposição de predicados, ou estrutura de evento, que se refere a uma representação semântica realizada através de predicados primitivos que ilustram os componentes de significados comuns a um determinado grupo de verbos (LEVIN e RAPPAPORT, 2005), estabelecemos as seguintes representações para os predicados psicológicos, adotando as decomposições de predicados propostas por Rappaport e Levin (1998) para os estados e os processos culminados, respectivamente:

(11) $[\mathrm{x}<S T A T E>]$

(12) [x CAUSE [ BECOME $[\mathrm{y}<S T A T E>]]]$

(RAPPAPORT e LEVIN, 1998, p. 108)

A representação em (11) caracteriza os predicados ExpSuj, os quais possuem apenas uma eventualidade, que é justamente o estado em que o Experienciador ' $x$ ' se encontra. A decomposição semântica em (12) corresponde aos verbos ExpObj, que são verbos causativos de mudança de estado. Esses predicados formam eventos complexos compostos por dois subeventos: o causador, representado pelo argumento ' $x$ '; e a mudança de estado que ele acarreta, resultando em um determinado estado - [BECOME [y $\langle$ STATE>]]. Nessa representação, o predicado primitivo 'BECOME' é o responsável por representar a mudança 
de estado sofrida pelo argumento ' $y$ ', que, nos predicados psicológicos, é o argumento Experienciador.

Essa interpretação causativa dos verbos ExpObj é amplamente abordada pelos trabalhos sobre os predicados psicológicos. Entretanto, essa natureza causal recebe diferentes análises, por exemplo, entre os trabalhos que analisam essa classe de verbos em português, apresentados nesta dissertação: Cançado (1995) considera que a causa faz parte do componente semântico das relações predicativas, sendo considerada, portanto, um papel temático, enquanto Naves (2005) argumenta que a causalidade refere-se a uma propriedade aspectual desses verbos.

\subsection{FUNDAMENTAÇÃo TEÓRICA}

Para a realização desta pesquisa, adotamos o arcabouço teórico da Gramática Gerativa, que fundamentalmente pressupõe que a capacidade dos seres humanos de adquirir uma língua natural é inata. Postula-se que todo homem é dotado de um órgão específico da linguagem - a Faculdade da linguagem -, cujo caráter básico é uma expressão de genes, assim como acontece com os outros órgãos.

O estágio cognitivo inicial da Faculdade da Linguagem é denominado de Gramática Universal (GU), a qual é considerada "um sistema de princípios e parâmetros" (CHOMSKY, 2006, p.13). Os princípios são universais, pois representam as características comuns a todas as línguas. Já os parâmetros marcam as diferenças entre as línguas, e sua fixação é determinada pela experiência sensível aos dados linguísticos. Vale ressaltar que os parâmetros, além de restritos, já são previstos pela Faculdade da Linguagem. A transição desse estado inicial para o estado estável constitui o processo de aquisição da gramática de uma língua particular. A Gramática Gerativa assume, também, o "argumento da pobreza de estímulo", ou seja, que o falante é exposto a enunciados incompletos, truncados e ambíguos. Esse argumento reforça a ideia de que o ser humano possui um dispositivo de aquisição de linguagem, visto que a criança adquire e domina, em curto espaço de tempo, o sistema de uma língua completa, mesmo recebendo inputs (dados linguísticos de entrada) limitados. Tornar explícitas as propriedades da competência linguística ou língua-I - conhecimento linguístico interno, individual e tácito de um falante - é o objetivo principal desse quadro teórico. 
O Programa Minimalista (doravante PM), modelo atual da teoria gerativa, considera que a Faculdade da Linguagem, juntamente com outros sistemas, compõe uma arquitetura mais ampla da mente/cérebro, e que as informações de uma língua particular devem cumprir as exigências impostas por esses sistemas (sistema articulatório-perceptual e sistema conceitual-intensional), isto é, devem satisfazer as 'condições de legibilidade' dos sistemas. Em outras palavras,o pressuposto de que a linguagem possui som e significado "traduz a tese de que a Faculdade da Linguagem emprega outros sistemas da mente/cérebro em dois níveis de interface" (CHOMSKY, 1998, p.45). Um dos níveis, a Forma Fonética (PF), está relacionado ao som - referente à representação fonética que uma estrutura da língua contém e deve ser legível aos sistemas sensório-motores (ou articulatório-perceptual), enquanto o outro nível, a Forma Lógica (LF), relaciona-se ao significado, visto que a representação semântica deve ser legível ao sistema conceitual.

O PM assume que uma língua-I é formada por dois componentes: um léxico e um sistema computacional. O léxico constitui o repertório das propriedades dos itens lexicais particulares. Essas propriedades são denominadas traços, os quais podem ser de três tipos: semânticos, fonológicos e formais. Os dois primeiros são responsáveis por estabelecer relações entre a língua e os sistemas de interface (conceitual-intensional e articulatórioperceptual, respectivamente), visto que os traços semânticos são interpretados na LF, que faz interface com o sistema conceitual-intensional, possibilitando que as expressões linguísticas assumam significado e referência no discurso, e os traços fonológicos são interpretados na PF, que faz interface com o sistema articulatório-perceptual, o que torna possível que os itens lexicais sejam manejados pelo aparato sensório-motor humano. Já os traços formais são de natureza morfossintática e são utilizados pelo sistema computacional, que é o componente responsável por combinar os traços do léxico e montar as estruturas sintáticas. Vale ressaltar que, mesmo que "os traços semânticos não sejam formais, traços formais podem ser semânticos com um significado intrínseco", e, portanto, podem operar no nível da computação (CHOMSKY, 1998, p. 52). Diante desse cenário, tem-se a seguinte arquitetura da Faculdade da Linguagem: 
(13)

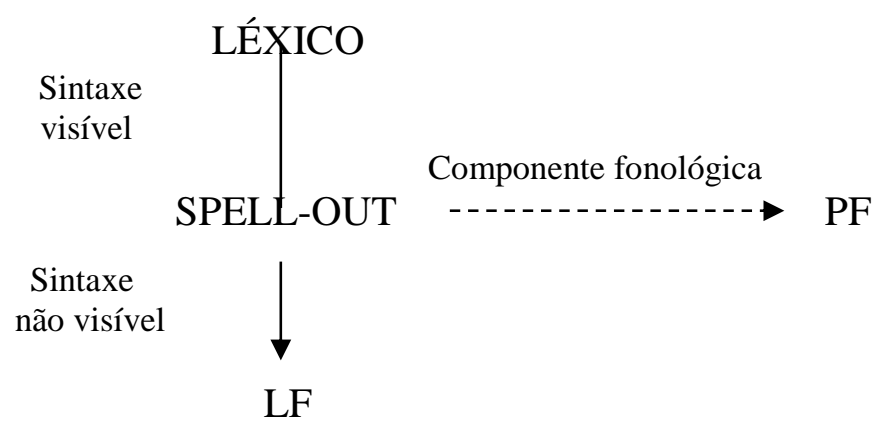

(CHOMSKY, 1995, TRADUÇÃO 1999, p. 27)

Essa representação ilustra o fato de o produto das operações sintáticas só serem manifestos quando ocorrem até spell-out - ponto da computação em que a estrutura formada é legível na Forma Fonética. Já as operações que acontecem após esse ponto da computação só se tornam visíveis em Forma Lógica e não têm suas informações enviadas ao sistema fonológico da arquitetura da Faculdade da Linguagem.

Para que o sistema computacional consiga modificar o input recebido por um falante, os itens lexicais devem estar em uma forma acessível ao sistema. Essa forma consiste em uma versão da teoria X-barra, que, basicamente, apresenta uma estrutura composta por projeções de núcleos selecionados a partir do léxico - nome, verbo, adjetivo e preposição (N, V, A e P, respectivamente), os quais estabelecem duas relações locais: (i) a relação especificador-núcleo (ZP e X), e (ii) a relação de núcleo-complemento (X e YP), como ilustrado abaixo:

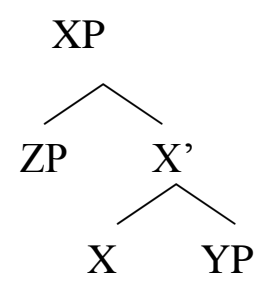

(CHOMSKY, 1995, TRADUÇÃO 1999, p. 249)

\subsection{OBJETIVOS}

O objetivo geral desta pesquisa é investigar se as construções perifrásticas dos predicados psicológicos no português brasileiro corroboram a hipótese de Landau (2010) de que todos os Experienciadores são cognitivamente locativos e os Experienciadores-objeto são gramaticalmente oblíquos. 
Como objetivos específicos, o presente trabalho pretende:

- analisar, a partir das construções perifrásticas dos verbos psicológicos, se existe alguma regularidade entre as propriedades das perífrases e o comportamento sintático desses verbos (ExpSuj e ExpObj);

- verificar se os verbos leves e as preposições usados nas perífrases refletem um padrão relevante para a análise dos predicados psicológicos;

- desenvolver o pressuposto de que o Experienciador é cognitivamente um locus mental, a partir de trabalhos que privilegiam a análise semântico-cognitiva dos eventos linguísticos;

- contribuir, no âmbito da teoria gerativa, para o estudo dos predicados psicológicos e do fenômeno de alternância sintática.

\subsection{ESTRUTURA DA DISSERTAÇÃO}

Além deste capítulo introdutório, esta dissertação está organizada em mais três capítulos. No Capítulo 2, expomos um breve panorama de propostas sobre os predicados psicológicos. Entre os trabalhos, encontra-se o de Landau (2010), que é de suma importância para esta pesquisa, uma vez que a sua proposta de que Experienciadores são, cognitivamente, locativos, além de serem oblíquos quando ocupam a posição de objeto, norteia grande parte do desenvolvimento deste trabalho. Apresentamos também as pesquisas de Cançado (1995) e Naves (2005) que, representam importantes estudos sobre esses predicados no português brasileiro e nos fornecem subsídios para a nossa análise das construções perifrásticas.

No Capítulo 3, discutimos o pressuposto de que o Experienciador é, cognitivamente, um locus mental (LANDAU, 2010), com base em trabalhos que partem das relações espaciais para a conceitualização da mente humana e, consequentemente, da linguagem (cf. JACKENDOFF, 1983; LAKOFF e JOHNSON, 1999; HUELVA UNTERNBÄUMEN, 2015), os quais nos permitem confirmar a hipótese de Landau (2010). Essas pesquisas também nos fornecem uma análise de outras categorias cognitivas, como posse e transferência, que são úteis para explicarmos as relações semânticas presentes nas construções perifrásticas dos predicados psicológicos.

No Capítulo 4, fornecemos generalizações para os componentes (verbo leve, nominalização e preposição) das construções perifrásticas e salientamos as diferenças e semelhanças entre as subclasses dos predicados ExpObj. Mostramos, também, que as 
nominalizações psicológicas nesse tipo de estrutura são estativas e propomos que os verbos leves das perífrases possuem propriedades predicadoras, formando, assim, junto com a nominalização, um predicado complexo.

A dissertação se encerra com as Considerações Finais e as Referências Bibliográficas, além de apresentar os dados que constituíram o corpus como Anexo. 


\section{CAPÍTULO 2}

\section{A LITERATURA SOBRE OS PREDICADOS PSICOLÓGICOS}

Uma vez que os verbos psicológicos possuem um comportamento intrigante para a teoria linguística, relacionado, fundamentalmente, a questões de mapeamento, encontram-se, na literatura, diversos estudos sobre esses predicados. Neste capítulo, apresentamos uma breve amostra dessas propostas teóricas, as quais foram selecionadas, levando em consideração o nosso objetivo de pesquisa neste trabalho: a descrição das construções perifrásticas dos predicados psicológicos no português brasileiro e a investigação sobre a hipótese de Landau (2010) de que os Experienciadores são cognitivamente locativos e, quando ocupam a posição de objeto do predicado, são gramaticalmente oblíquos.

Na seção 2.1, introduzimos o trabalho seminal de Belletti e Rizzi (1988), realizado no âmbito da Teoria Gerativa, que propõe uma análise para os predicados psicológicos a partir das informações lexicais temáticas e de Caso. Para a seção 2.2, selecionamos duas propostas de análise para os predicados psicológicos no português do Brasil - Cançado (1995) e Naves (2005) -, as quais são desenvolvidas em diferentes arcabouços teóricos, mas trazem considerações significativas para o nosso trabalho com as perífrases do português. Na seção 2.3, apresentamos dois trabalhos - Arad (1998) e Landau (2010) -, que, em comum, desenvolvem propostas que, de diferentes maneiras, estabelecem análises locativas para os predicados psicológicos, além de estenderem suas pesquisas às construções perifrásticas. $\mathrm{O}$ capítulo se encerra com uma síntese dos principais pontos abordados em cada um desses trabalhos, salientando os aspectos relevantes para a nossa pesquisa.

\subsection{O TRABALHO SEMINAL DE BELLETTI E RIZZI (1988)}

Belletti e Rizzi (1988) desenvolvem uma análise para os predicados psicológicos do italiano a partir do pressuposto de que as entradas lexicais dos verbos contêm, pelo menos, 
duas informações: a grade temática (grade- $\theta$ ) e a grade de Caso. Com base nessas considerações, os autores estabelecem três classes lexicais para os verbos psicológicos: (i) classe de temere 'temer'; (ii) classe de preoccupare 'preocupar'; e (iii) classe de piacere 'agradar', ilustradas em (1), (2) e (3), respectivamente:

(1) Gianni teme questo.

'João teme isto'

Grade- $\theta$ : [Experienciador, Tema]

Grade de Caso: [ - , - ]

(2) Questo preoccupa Giani.

'Isto preocupa João'

Grade- $\theta$ : [Experienciador, Tema]

Grade de Caso: [ACC, - ]

(3) a. Questo piace a Giani. ${ }^{4}$

b. A Gianni piace questo

'Isto agrada ao João'

Grade- $\theta$ : [Experienciador, Tema]

Grade de Caso: [DAT, - ]

(BELLETTI e RIZZI, 1988, p. 291 e 344)

A representação lexical das três classes é basicamente a mesma, uma vez que possuem a mesma grade- $\theta$, apresentando diferença apenas na grade de Caso. Na classe de temere, o argumento Experienciador é selecionado como papel- $\theta$ externo e não possui Caso inerente, diferentemente das outras duas classes, que, na proposta dos autores, não possuem papel- $\theta$

\footnotetext{
${ }^{4}$ Belletti e Rizzi (1988) apontam a classe de piacere como sendo a única a permitir duas ordens lineares: (i) Tema - Verbo - Experienciador; e (ii) Experienciador - Verbo - Tema (cf. (3a) e (3b), respectivamente). Segundo os autores, isso é possível devido ao fato de o Experienciador constituir um sintagma com a preposição marcadora de caso 'a'. Nessas condições, a preposição é que rege o NP Experienciador, permitindo, assim, que ele se movimente livremente, dando origem a duas estruturas superficiais distintas. Vale ressaltar que os predicados dessa classe possuem a mesma estrutura profunda dos verbos da classe de preoccupare (cf. (4b)), entretanto, como nesta classe o Experienciador é marcado com Caso inerente acusativo, ele não possui um marcador de Caso diferente do verbo, como a preposição, e, portanto, não pode se mover livremente.
} 
externo, e em que o Experienciador é lexicalmente especificado para Caso - acusativo, na classe de preoccupare, e dativo, na de piacere. ${ }^{5}$

Em princípio, a problemática dos verbos psicológicos reside no mapeamento de seus argumentos, pois, levando em consideração as estruturas superficiais das três classes, o princípio teórico de que a informação temática e a configuração sintática são relacionadas de forma sistemática não é atestado. Entretanto, Belletti e Rizzi (1988) afirmam que as estruturas profundas das três classes dos verbos psicológicos amenizam as diferenças presentes na ordem linear desses verbos, começando pelo fato de as três classes serem derivadas a partir de duas configurações na estrutura profunda: os predicados da classe temere derivam da estrutura transitiva, em (4a), e os da classe de preoccupare e piacere, da estrutura inacusativa, em $(4 \mathrm{~b}){ }^{6}$

(4) a. S<smiles>CCC</smiles>

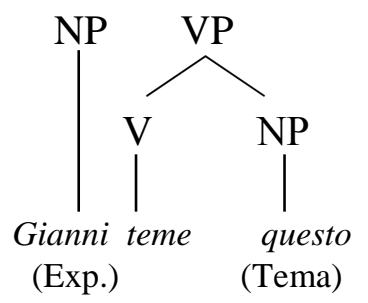

b.

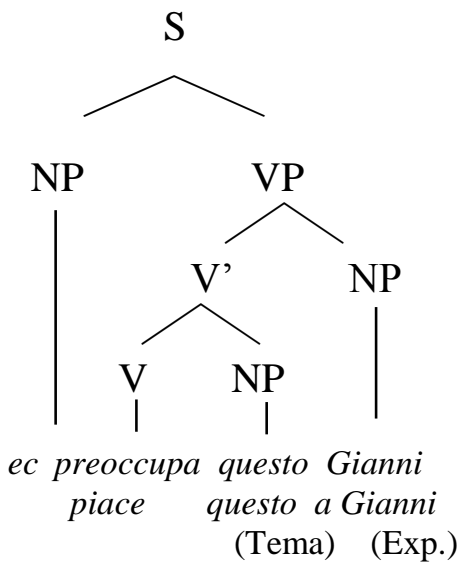

(BELLETTI e RIZZI, 1988, p.293)

Para o mapeamento entre as grades temáticas e as representações sintáticas dos verbos ocorrer de forma sistemática, ele precisa seguir o princípio de que um papel- $\theta$ proeminente dever ser projetado em uma configuração estrutural proeminente. Nesse cenário, Belletti e Rizzi (1988) propõem o seguinte princípio para explicar a relação de proeminência da grade- $\theta$ dos predicados psicológicos:

\footnotetext{
${ }^{5}$ O Caso inerente é atribuído no léxico e está associado a um papel temático específico, diferentemente do Caso estrutural, que é independente de papéis temáticos e é checado em uma certa configuração sintática.

${ }^{6} \mathrm{Na}$ representação em (4b), Belletti e Rizzi (1988) indicam que a projeção máxima irmã de V' é ocupada por um NP. Esse sintagama representa apenas a categoria a que pertence o argumento Experienciador dos verbos de preoccupare, visto que o Experienciador da classe de piacere não é um NP, e sim um sintagma preposicionado PP (cf. a Gianni).
} 
(5) Dada a grade- $\theta$ [Experienciador, Tema], o Experienciador é projetado em uma posição mais alta que o Tema. ${ }^{7}$

(BELLETTI e RIZZI, 1988, p.344)

A partir desse pressuposto, as duas configurações da estrutura profunda dos verbos psicológicos (cf. (4)) estabelecidas por Belletti e Rizzi (1988) exibem uma projeção em que o argumento Experienciador está em uma posição mais alta que o Tema. Na classe de temere (4a), o Experienciador é selecionado como papel- $\theta$ externo e não possui Caso inerente, e o Tema recebe Caso acusativo do verbo, resultando, assim, em uma estrutura transitiva simples, em que o Experienciador encontra-se na posição de sujeito, que é proeminente em relação à posição de complemento do Tema. Já a estrutura profunda dos verbos da classe de preoccupare e de piacere (4b), de acordo com os autores, é uma estrutura de duplo objeto, visto que ambos os argumentos são internos ao VP. A fim de que essa estrutura se enquadre nas exigências estabelecidas em (5), o Experienciador é projetado como irmão de V', pois, nessa configuração, esse argumento está em uma posição mais alta que o Tema, que é complemento de V.

Belletti e Rizzi (1988) acrescentam que essas estruturas profundas dos verbos psicológicos compartilham uma importante propriedade: "o verbo $\theta$-marca diretamente o Tema, e o constituinte verbo + Tema $\theta$-marca composicionalmente o Experienciador" (BELLETTI e RIZZI, 1998, p. 293-294). ${ }^{8}$ Dessa forma, além de a estrutura profunda obedecer à proeminência existente entre as relações temáticas, a marcação dessas relações também ocorre por meio do mesmo processo nas três classes psicológicas, diminuindo, assim, a grande discrepância entre as estruturas superficiais das classes dos predicados psicológicos.

Com relação à ordem linear dos predicados psicológicos, a classe de temere já possui uma estrutura superficial configurada com a mesma ordem em que os argumentos se manifestam na estrutura profunda. Por outro lado, a estrutura profunda das classes de preoccupare e de piacere, por ser uma estrutura inacusativa, não projeta nenhum argumento temático na posição de sujeito. Para explicar o fato de o Tema ocupar a posição de sujeito na estrutura superficial, os autores baseiam-se na Generalização de Burzio - que postula que um verbo só atribui Caso acusativo se atribuir papel- $\theta$ externo - e argumentam que, como os

\footnotetext{
${ }^{7}$ No original: Given a $\theta$-gird [Experiencer, Theme], the Experiencer is projected to a higher position than the Theme.

${ }^{8}$ No original: the verb directly $\theta$-marks the Theme, and the constituent Verb + Theme compositionally $\theta$-marks the Experiencer.
} 
predicados dessas classes não possuem argumento externo e não podem, consequentemente, atribuir Caso Acusativo, além de o Experienciador já possuir Caso inerente especificado no léxico, o Tema é o único argumento que pode ser alçado para a posição de sujeito, resultando nas ordens lineares atestadas em (2) e (3).

A análise inacusativa proposta por Belletti e Rizzi (1988) para os predicados de preoccupare e de piacere é pautada em duas evidências. ${ }^{9}$ A primeira refere-se ao fato de o sujeito desses predicados apresentar propriedades prototípicas de sujeito derivado, uma vez que, diferentemente do comportamento associado ao sujeito profundo, como o sujeito da classe de temere, o sujeito dessas duas classes não permite:

- ligar-se a um clítico anafórico;

(6) a. *Gianni si preoccupa.

'João se preocupa'

b. Gianni si teme.

'João se teme'

- receber interpretação de pro arbritário;

(7) a. *[...] pro hanno preoccupato il governo. 'preocuparam o governo'

b. [...] pro hanno temuto il terremoto. 'temeram o terremoto'

- ser estrutura subordinada de construção causativa;

(8) a. *Questo lo ha fato preoccupare ancora di più a Mario. 'Isto o fez preocupara ainda mais Mário'

b. Questo lo ha fatto temere ancora di più a Mario.

'Isto o fez temer ainda mais Mário'

- formar passivas sintáticas. ${ }^{10}$

(9) a. *Sono stancato dalle sue idee.

\footnotetext{
${ }^{9}$ É importante ressaltar que Belletti e Rizzi (1988) elaboram os testes especificamente com verbos da classe de preoccupare, entretanto, os autores estendem os resultados obtidos aos verbos da classe de piacere.

${ }^{10}$ De acordo com Belletti e Rizzi (1988), os verbos das classes de preoccupare e piacere não formam passivas sintáticas, mas participam de passivas adjetivas, como ilustrado em (9b).
} 
'Sou cansado pelas suas ideias'

b. Sono stanco dele sue idee.

'Estou cansado das suas ideias'

(BELLETTI e RIZZI, 1988, p. 296-311)

A segunda evidência é a de que o Experienciador não é transparente ao processo de extração de material, que é uma propriedade típica de objeto canônico (cf. (10)). Esse teste, segundo os autores, corrobora a proposta de que o Experienciador é projetado na posição de irmão de V' na estrutura profunda (cf. (4b)), pois, dessa forma, ele está como um tipo de segundo objeto, e não está ocupando a posição de objeto canônico, que seria a de complemento de V.

(10) *La Ragazza di cui Gianni preoccupa il padre.

'A garota de quem João preocupa o pai'

(BELLETTI e RIZZI, 1988, p. 325)

Quanto à importante questão suscitada pelos predicados psicológicos das classes de preoccupare e piacere, referente à ligação excepcional de anafórico (cf. (11)), em que ocorre uma aparente violação da relação de c-comando, visto que a anáfora sé 'se' antecede o seu referente (Gianni), Belletti e Rizzi (1988) argumentam que essa violação não ocorre em sentenças como (11), pois, com base na estrutura profunda desses predicados proposta pelos autores (cf. (4b)), constata-se que o referente, que é projetado na posição irmã de V', antecede a anáfora, que é parte do complemento do verbo. ${ }^{11} \mathrm{Na}$ visão de Belletti e Rizzi, portanto, as exigências de relações de c-comando são satisfeitas nível de estrutura profunda.

(11) Questi pettegolezzi su di sé preoccupano Gianni più di ogni altra cosa.

'Estes rumores sobre si mesmo preocupam João mais que qualquer outra coisa'

(BELLETTI e RIZZI, 1988, p. 312, grifo do autor)

11 Define-se c-comando como: “ $\alpha$ c-comanda $\beta$ se não domina $\beta$ e todo o $\gamma$ que domina $\alpha$ domina $\beta$." (CHOMSKY, 1995, TRADUÇÃO 1999, p. 76). Por exemplo, em uma representação como (i), a seguir, B ccomanda C, F e G; e C c-comanda B, D e E.

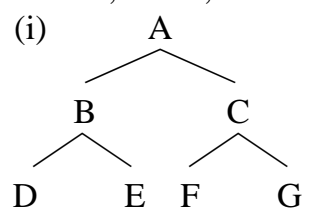


O trabalho de Belleti e Rizzi (1988) representa uma importante contribuição para o estudo dos predicados psicológicos. A partir dele, um grande número de trabalhos foi desenvolvido posteriormente. Como poderemos observar ao longo deste capítulo, a proposta dos autores é tomada como ponto de partida em diferentes trabalhos e sob diferentes aspectos: por exemplo, Cançado (1995) testa quais são as propriedades sintáticas específicas dos predicados psicológicos, elencadas pelos autores, no português brasileiro, enquanto Arad (1998) utiliza essas propriedades para estabelecer a proposta de que os verbos psicológicos são classificados segundo diferentes tipos de leitura aspectual.

\subsection{OS PREDICADOS PSICOLÓGICOS NO PORTUGUÊS BRASILEIRO}

Nesta seção, apresentamos duas análises para os predicados psicológicos no português brasileiro. A subseção 2.2.1 exibe a proposta de Cançado (1995), desenvolvida com base no arcabouço da Teoria Generalizada dos Papéis Temáticos, que destaca o papel da semântica na estruturação das expressões de uma língua. $\mathrm{Na}$ seção 2.2.2, realizamos uma breve apresentação da pesquisa de Naves (2005), que, pautada na Teoria Gerativa, propõe uma explicação para o fenômeno da alternância sintática por meio dos traços abstratos dos itens lexicais.

\subsubsection{Cançado (1995)}

A proposta de Cançado (1995) tem como referencial teórico a Teoria Generalizada dos Papéis Temáticos, que fundamentalmente assume a existência de uma relação de dependência entre a estrutura argumental sintática e a estrutura temática dos predicadores das sentenças. A autora analisa empiricamente os predicados psicológicos do português brasileiro, agrupandoos, segundo as suas propriedades sintáticas e suas propriedades semânticas, relacionadas às grades temáticas. Os testes sintáticos aplicados a esses verbos foram os seguintes, sendo os três últimos, propostos por Belletti e Rizzi (1988) - os dados (12) a (17) são de Cançado (1995, p. 187-222): 
- a capacidade de o predicado aceitar construções ergativas, $;^{12}$

(12) a. *O cachorro (se) teme pelo seu tamanho.

b. A mãe (se) preocupava com a arrogância de Rosa.

c. A multidão (se) acalma com as ameaças da polícia.

d. José (se) animou com os argumentos de Maria.

- a capacidade de o predicado aceitar a causativização com a promoção do terceiro argumento para a posição de sujeito;

(13) a. *O tamanho teme o cachorro.

b. A arrogância de Rosa preocupava a mãe.

c. As ameaças da polícia acalmam a multidão.

d. Os argumentos de Maria animaram José.

- a capacidade de o predicado aceitar a inversão dos dois últimos argumentos;

(14) a. José teme o tamanho do cachorro.

b. *Rosa preocupava a arrogância da mãe.

c. *A polícia acalma as ameaças da multidão.

d. *Maria animou os argumentos de José.

- a possibilidade de o predicado apresentar passivização sintática ou adjetiva;

(15) a. *O cachorro fica temido com José.

O cachorro é temido por José.

b. A mãe ficava preocupada com a arrogância de Rosa.

*A mãe foi preocupada por Rosa.

c. *A multidão ficou acalmada com a polícia.

A multidão foi acalmada pela polícia.

d. José ficou animado com os argumentos de Maria.

José foi animado por Maria.

\footnotetext{
${ }^{12}$ Os testes foram aplicados levando em consideração as orações a seguir, as quais possuem, como referido pela autora, um terceiro argumento preposicionado, além dos dois argumentos prototípicos dos predicados psicológicos (Tema e Experienciador):

(i) José teme o cachorro pelo seu tamanho.

(ii) Rosa preocupava a mãe com sua arrogância.

(iii) A polícia acalma a multidão com suas ameaças.

(iv) Maria animou José com seus argumentos.
} 
- a possibilidade de o predicado ter uma interpretação arbitrária quando há um pro como sujeito da oração;

(16) a. Temem o cachorro pelo seu tamanho.

b. *Preocupam a mãe com aquela arrogância.

c. Acalmaram a multidão com aquelas ameaças.

d. Animaram José com aqueles argumentos.

- a possibilidade de o predicado permitir orações causativas encabeçadas, utilizando-se do operador fazer.

(17) a. O amigo faz José temer o cachorro.

b. *O pai fazia Rosa preocupar a mãe.

c. O coronel fez a polícia acalmar a multidão.

d. João fez Maria animar José.

Diante dos resultados dos testes, e considerando, também, as propriedades relacionadas ao mapeamento do Experienciador e à possibilidade de ligação excepcional de anafórico (ilustrada na nossa apresentação do trabalho de Belletti e Rizzi (1998) na seção 2.1), a autora classifica os verbos em quatro subclasses, descritas conforme o quadro abaixo (temer, preocupar, acalmar e animar são os verbos escolhidos pela autora como os representantes de cada uma das classes dos predicados psicológicos):

(18)

\begin{tabular}{|c|c|c|c|}
\hline $\begin{array}{c}\text { CLASSE 1 } \\
\text { temer }\end{array}$ & $\begin{array}{c}\text { CLASSE 2 } \\
\text { Preocupar }\end{array}$ & $\begin{array}{c}\text { CLASSE 3 } \\
\text { acalmar }\end{array}$ & $\begin{array}{c}\text { CLASSE 4 } \\
\text { animar }\end{array}$ \\
\hline Exp. Sujeito & Exp. Objeto & Exp. Objeto & Exp. Objeto \\
\hline - lig. anafórica & + lig. anafórica & + lig. anafórica & + lig. anafórica \\
\hline - constr. ergativas & + constr. ergativas & + constr. ergativas & + constr. ergativas \\
\hline - causativização & + causativização & + causativização & + causativização \\
\hline + inversão & - inversão & - inversão & - inversão \\
\hline + passiva sintática & + passiva adjetiva & + passiva sintática & + passiva sint. e adj. \\
\hline + pro & - pro & + pro & + pro \\
\hline + causativas & - causativas & + causativas & + causativas \\
\hline
\end{tabular}

(CANÇADO, 1995, p.31) 
As diferenças mais marcantes da classe 1 em relação às demais classes são a realização do argumento Experienciador na posição de sujeito e a impossibilidade da ligação excepcional de anafóricos. A autora argumenta que a classe 3 permite que a posição do sujeito tenha papel temático tanto de Causa como de Agente (cf. (19)), diferentemente da classe 2 (cf. (20)), que não permite que o papel- $\theta$ de Agente seja atribuído ao sujeito, permitindo apenas o de Causa:

(19) a. As ameaças da polícia acalmam a multidão. [Causa]

b. João acalma Maria com um chá. [Agente]

(20) João preocupa Maria com sua chegada. ${ }^{13} \quad\left[{ }^{*}\right.$ Agente,,${ }^{o k}$ Causa $]$

(CANÇADO, 1995, p. 47- 48)

Os verbos da classe de acalmar também apresentam propriedades sintáticas distintas dos verbos da classe de preocupar: participam apenas de construções passivas sintáticas; admitem pro arbitrário e aceitam construções causativas com o auxiliar fazer. Já os verbos do tipo animar exibem todas as propriedades atribuídas tanto à classe 2 quanto à classe 3 , o que sugere que o sujeito desses verbos tenha o papel- $\theta$ de Causa ou de Agente:

(21) Maria animou José com sua beleza.

[Causa]

(22) Maria animou José com uma bebida forte.

[Agente]

(CANÇADO, 1995, p. 50)

A autora ressalta que a diferença entre as classes 3 e 4 , já que ambas admitem duas redes temáticas, está no fato de que as propriedades sintáticas da classe de acalmar são determinadas por sua característica agentiva, enquanto a classe de animar apresenta propriedades das classes 2 e 3, isto é, propriedades agentivas e não agentivas, por exemplo, admite passivas sintáticas (classe 3 ) e passivas adjetivas (classe 2):

(23) a. José foi animado por Maria.

b. José ficou animado com a beleza de Maria.

\footnotetext{
${ }^{13}$ A marcação da agramaticalidade do dado (20) refere-se à impossibilidade de interpretação agentiva do sujeito. Entretanto, a sentença é uma construção gramatical no português brasileiro numa leitura causativa.
} 
(CANÇADO, 1995, p. 51)

Cançado (1995) adota uma classificação refinada dos papéis temáticos e propõe a seguinte hierarquia temática para os predicados psicológicos, baseada em macrofunções, que agrupam os papéis temáticos que compartilham propriedades comuns, sobre as quais se podem estabelecer generalizações sobre a correlação entre a semântica e a sintaxe. ${ }^{14,15}$

\section{(24) CAUSA > OBJETO AFETADO > ESTATIVO}

(CANÇADO, 1995, p. 133)

A autora estabelece três macrofunções: (i) CAUSA, que engloba os papéis temáticos de Agente, Causa e Instrumento, os quais compartilham a propriedade de possuir algum papel no desencadeamento do processo; (ii) OBJETO AFETADO, que se caracteriza pela propriedade de o argumento ser afetado pelo processo, e compreende o Paciente como um dos papéis- $\theta$; e (iii) ESTATIVO, que se refere ao papel- $\theta$ de Objetivo, atribuído a um argumento que não sofre qualquer mudança de estado.

Segundo Cançado (1995), outra noção semântica importante na caracterização dos predicados psicológicos é a de controle. Para a autora, o argumento na posição de sujeito dos verbos de tipo preocupar recebe o papel semântico de Causa, pois ele tem um papel no desencadeamento do processo, mas não apresenta nenhum tipo de controle. Já o argumento sujeito dos verbos da classe de acalmar pode ser um Agente, o que acarreta o seu controle sobre o processo descrito pelo verbo. Mediante a possibilidade de esse argumento possuir mais de um tipo semântico que tem como propriedade comum a de desencadear um processo, esse argumento é rotulado pela macrofunção CAUSA. Como os verbos do tipo animar exibem as propriedades das outras duas classes, eles também pertencem à macrofunção CAUSA, mas distinguem-se da classe 3 quanto à noção de controle, já que o sujeito pode ou

\footnotetext{
14 "Hierarquia temática é a lista ordenada da correlação de papéis temáticos e funções definidas na sintaxe" (CANÇADO, 1995, p.12).

${ }^{15}$ As macrofunções são grafadas todas com letra maiúscula, como CAUSA, para que não haja confusão com os papéis- $\theta$, no caso, com o papel de Causa. A teoria de macrofunções de Cançado (1995) baseia-se na proposta de Dowty (1991 apud CANÇADO, 1995), que estabelece a divisão dos papéis temáticos em duas funções básicas: Proto-Agente e Proto-Paciente. Essa divisão é definida a partir de uma lista de acarretamentos verbais, por exemplo, um argumento Proto-Agente está associado a propriedades como envolvimento volitivo no evento ou estado; percepção ou sensação; causar um evento ou mudança de estado em outro participante, enquanto um argumento Proto-Paciente sofre mudança de estado; causalmente é afetado por outro participante; e é imóvel em relação ao outro participante.
} 
não carregar esse traço semântico. Ao segundo argumento dessas três classes atribui-se o papel- $\theta$ de Experienciador, que representa o argumento afetado pelo processo. Diante desse cenário, a autora estabelece a seguinte rede temática para os predicados psicológicos:

(25) a. TEMER: V, $\left\{\right.$ Experienciador ${ }^{+ \text {controle }}$, Objetivo $\}$

b. PREOCUPAR: V, $\left\{\right.$ Causa $^{\text {-controle }}$, Experienciador $\left.{ }^{\text {afetado }}\right\}$

c. ACALMAR: V, $\left\{\right.$ CAUSA $^{\text {+controle }}$, Experienciador $\left.{ }^{\text {afetado }}\right\}$

d. ANIMAR: V, $\left\{\mathrm{CAUSA}^{+/- \text {controle }}\right.$, Experienciador $\left.{ }^{\text {afetado }}\right\}$

(CANÇADO, 1995, p. 147-149)

A classe dos verbos de temer exibe um argumento Experienciador na posição de sujeito, que tem controle sobre o estado ou processo em que se encontra, e possui, na posição de objeto, um argumento de papel- $\theta$ de Objetivo, o qual não sofre uma mudança de estado e a sua relação com o primeiro argumento é responsável por caracterizar o estado do sujeito.

Cançado (1995) considera que as diferentes relações semânticas que os verbos psicológicos apresentam com seus argumentos (diátese verbal), como apresentado em (25), associam-se a diferentes restrições sintáticas, segundo a hierarquia apresentada em (24). Por exemplo, a autora argumenta que apenas o verbo que possui um papel- $\theta$ da macrofunção CAUSA na posição de sujeito e que tem um argumento OBJETO AFETADO na posição de objeto da construção transitiva licencia a alternância sintática.

Nesse contexto, os verbos da classe temer não se submetem à alternância sintática e, consequentemente, não apresentam a construção intransitiva (26b), devido ao fato de o argumento interno desses verbos receber papel temático Objetivo, que integra a macrofunção ESTATIVO.

(26) a. José teme o cachorro.

b. ${ }^{*} \mathrm{O}$ cachorro se teme.

Já os verbos das classes 2, 3 e 4 possuem a grade temática \{Causa/CAUSA, OBJETO AFETADO\}, ou seja, cumprem as condições semânticas/temáticas exigidas para que os seus argumentos sejam mapeados em duas configurações distintas:

(27) a. Rosa preocupa a mãe. 
b. A mãe se preocupa.

(28) a. Maria acalma/anima José.

b. José se acalma/anima.

(CANÇADO, 1995, p. 168)

\subsubsection{Naves (2005)}

O trabalho de Naves (2005) tem como foco principal explicar o problema da alternância sintática dos predicados psicológicos. Pelo comportamento sintático heterogêneo dos verbos psicológicos quanto à possibilidade de o verbo mapear seus argumentos em estruturas sintáticas distintas, a autora adota uma divisão bipartite para as classes desses verbos no português. A primeira classe refere-se aos verbos do tipo de temer, que projetam o argumento Experienciador sempre na posição de sujeito (ExpSuj) da estrutura transitiva e não admitem a alternância verbal. Já o segundo conjunto - verbos do tipo de preocupar - atribui o papel temático de Experienciador à posição de objeto (ExpObj) na estrutura transitiva e admite alternância.

A autora aponta que as classes dos predicados psicológicos se diferenciam ainda quanto à classificação aspectual: a classe de temer denota estados, e a de preocupar denota eventos causativos. Muitos teóricos atribuem a explicação da alternância sintática a essas propriedades semânticas de base aspectual (GRIMSHAW, 1990; PESETSKY, 1995; BOUCHARD, 1995; REINHART, 2000, 2001 apud NAVES, 2005). Dentre elas, está a propriedade semântica de causação - presente no argumento externo dos verbos da classe de preocupar. Essa ideia sustenta-se no contraste da classificação aspectual dos psicológicos entre estativos e causativos. Entretanto, Naves (2005) ressalta que, por mais que o componente de significado causatividade seja relevante para a análise dos predicados psicológicos alternantes, ele não é suficiente para explicar o porquê de alguns verbos sofrerem alternância e outros não, pois não são todos os verbos causativos que alternam:

(29) a. João / O vento derrubou o vaso.

b. *O vaso derrubou.

(NAVES, 2005, p.156) 
Naves (2005) também desenvolve uma análise para outra propriedade semântica relacionada aos predicados psicológicos ExpObj: o controle. Essa propriedade está relacionada ao fato de o protagonista de um evento exercer controle sobre os resultados desse evento; entretanto, pelo fato de esses verbos serem decompostos semanticamente em duas eventualidades (o evento causador e o evento causado), a autora considera que o controle acontece de maneira diferenciada para os verbos psicológicos. Para ela, a propriedade controle refere-se ao fato de o protagonista controlar a eventualidade que causa o evento psicológico, mas não de controlar o evento psicológico em si, o qual seria propriamente o resultado do evento causativo. Essa proposta diferencia-se da análise apresentada por Cançado (1995), que considera que o controle é uma propriedade que recai sobre o processo descrito pelo verbo, isto é, incide diretamente no processo expresso pelo verbo psicológico.

À luz do Programa Minimalista, que tem como hipótese o fato de que a derivação sintática é realizada com base em traços abstratos dos itens lexicais, Naves (2005) propõe uma mudança de perspectiva do que se tinha na literatura para explicar o fenômeno da alternância sintática (no caso, da psicológica), que até então focava as propriedades do sujeito. A autora assume que os traços importantes para explicar a alternância relacionam-se ao predicado, uma vez que a gramática da língua permite que um evento seja expresso apenas pela relação entre o verbo e o seu argumento interno, como representado pelo esquema a seguir: ${ }^{16}$

(30) a. Argumento externo - V - Argumento interno $\rightarrow$ Sentença transitiva b. ..........-V - Argumento interno $\rightarrow$ Sentença intransitiva

(NAVES, 2005, p.156)

Considerando que as sentenças alternantes são interpretadas como estruturas de evento, Naves (2005) parte de uma leitura aspectual desses predicados, com o objetivo de determinar os traços abstratos dos itens lexicais que licenciam ou não a alternância. Utilizando-se da proposta de Vendler (1967) para a tipologia de eventos, a autora atesta que as classes de estados (cf. (31)) e de atividades (cf. (32)) não admitem alternância, enquanto processos culminados (cf. (33)) e culminações (cf. (34)) admitem.

\footnotetext{
${ }^{16}$ Como os verbos psicológicos alternantes possuem uma interpretação de causa, a autora estende sua explicação para o processo de alternância aos predicados causativos em geral (i), e, consequentemente, a representação em (30) também reflete o comportamento desses verbos:
}

(i) a. João balançou a corda.

b. A corda balançou. 
(31) a. O governo teme a inflação.

b. *A inflação (se) teme (com o governo).

(32) a. João quebra coco na praia.

b. *Coco quebra na praia.

(33) a. Os patrões acalmaram os manifestantes.

b. Os manifestantes se acalmaram.

(34) a. Os palhaços assustaram as crianças.

b. As crianças (se) assustaram (com os palhaços).

(NAVES, 2005, p. 157)

A partir da definição das classes aspectuais feita por Smith (1991) - a qual se utiliza de três pares de traços abstratos (estático vs. dinâmico; durativo vs. instantâneo; télico vs. atélico) para caracterizar essas classes -, Naves (2005) sistematiza a proposta de atribuições de traços para as classes aspectuais em combinação com a propriedade de a classe permitir ou não a alternância sintática.

\begin{tabular}{|c|c|c|}
\hline Classe Aspectual & Traços & Alternância \\
\hline Estados & [estático, durativo, atélico] & Não \\
\hline Atividades & [dinâmico, durativo, atélico] & Não \\
\hline Processos Culminados & [dinâmico, durativo, télico] & Sim \\
\hline Culminações & [estático, instantâneo, télico] & Sim \\
\hline
\end{tabular}

(NAVES, 2005, p. 158)

Mediante o resultado da análise dos traços atribuídos às classes aspectuais em relação ao processo de alternância, a autora constata que o traço formal que difere os verbos alternantes (processos culminados e culminações) dos verbos não alternantes (estados e atividades) é o da telicidade, o qual se caracteriza por atribuir ao evento um ponto final, na perspectiva da semântica lexical desses verbos.

Naves (2005) ressalta, porém, que não são todos os verbos das classes de processos culminados e culminações que permitem a alternância: 
(36) a. Os pescadores construíram uma jangada.

b. *Uma jangada (se construiu).

(37) a. João atingiu o topo da montanha.

b. * O topo da montanha (se) atingiu.

(NAVES, 2005, p. 159)

A partir da evidência de que há predicados télicos, como nos dados acima, que não licenciam duas configurações sintáticas distintas para expressarem seus argumentos, Naves (2005) propõe que isso é decorrente de o argumento interno não possuir a interpretação de mudança de estado. Jangada e topo da montanha apenas delimitam o evento expresso pelo verbo. A autora constata, portanto, que o traço [télico] dos verbos deve estar associado ao traço [mudança de estado] para que um dado predicado alterne.

Em suma, Naves (2005) defende que são dois os traços abstratos dos itens lexicais necessários para explicar o fenômeno da alternância sintática dos predicados psicológicos (e dos causativos): o traço [télico] e o traço [mudança de estado]. A composição desses traços licencia a alternância, ao passo que a ausência de um ou dos dois traços caracteriza os predicados não alternantes.

Quanto ao problema do mapeamento dos argumentos dos predicados psicológicos alternantes (classe de preocupar), Naves (2005) propõe que o verbo, possuidor do traço [télico], mapeia o argumento detentor do traço [mudança de estado] na posição de argumento interno. Assim, é o Experienciador que ocupa a posição de argumento interno, enquanto o Tema preenche a posição de argumento externo da estrutura transitiva. Dessa maneira, explica também por que é o argumento externo que não aparece na estrutura intransitiva dos verbos alternantes, visto que o "fato de o verbo alternante representar um processo télico exige que o seu argumento interno seja expresso e isso é uma condição suficiente para licenciar a expressão [V + argumento interno] como uma sentença" (NAVES, 2005, p.180). Com relação ao mapeamento dos verbos não alternantes - classe de temer -, a autora argumenta que esses verbos possuem o traço [atélico], o que não produz uma leitura na mudança de estado do Experienciador que justifique mapeá-lo na posição de argumento interno. Assim, o 
Experienciador é mapeado na posição de argumento externo, pois possui mais propriedades prototípicas de sujeito do que o argumento Tema. ${ }^{17}$

\subsection{PROPOSTAS LOCATIVAS PARA OS PREDICADOS PSICOLÓGICOS}

Nesta seção, apresentamos duas propostas teóricas que exibem uma análise locativa para os predicados psicológicos, mesmo que de formas distintas. Além disso, ambos os trabalhos estendem suas pesquisas às construções perifrásticas desses verbos, o que pode nos fornecer subsídios para a nossa análise das perífrases no português brasileiro.

O primeiro trabalho, Arad (1998), propõe que uma das três construções possíveis para os verbos ExpObj é a construção locativa, na qual o argumento Experienciador pode tanto ser a 'coisa' que está localizada em um estado quanto pode ser um contêiner em que um estado está localizado. Enquanto a estrutura locativa é apenas um dos tipos de construção para os predicados com Experienciador na posição de objeto, os verbos ExpSuj são essencialmente locativos.

Na subseção 2.3.2, apresentamos a análise de Landau (2010) para os predicados psicológicos, que, fundamentalmente, propõe que todos os Experienciadores são cognitivamente locativos e que, no caso dos predicados ExpObj essa propriedade tem como contrapartida o fato de que o argumento Experienciador é, gramaticalmente, um argumento oblíquo.

\subsubsection{Arad (1998)}

O trabalho de Arad (1998), para os verbos psicológicos, tem como escopo principal os predicados em que o argumento Experienciador é lexicalizado na posição de objeto - verbos ExpObj. Levando em consideração a estrutura de evento desses predicados, isto é, as suas propriedades aspectuais, a autora argumenta que eles podem ter três diferentes leituras:

\footnotetext{
${ }^{17}$ Naves (2005, p.181), utilizando as propriedades características de sujeitos prototípicos, apontadas por Keenan (1976 apud NAVES, 2005), afirma que os Experienciadores dos verbos ExpSuj são especificados para as seguintes propriedades: existência independente; indispensabilidade; referência autônoma; controle; previsibilidade; agente; e destinatário (em orações imperativas). Em contrapartida, o Tema é especificado apenas para: existência independente e referência autônoma.
} 
estativa, eventiva e agentiva. Essas leituras são determinadas a partir de duas propriedades: (i) se há um Agente, o qual deliberadamente faz algo a fim de desencadear um estado mental no Experienciador, e (ii) se há uma mudança de estado mental no Experienciador.

A leitura agentiva apresenta as duas propriedades, ou seja, possui um Agente, e o Experienciador sofre uma mudança de estado mental (cf. (38)). Em um predicado de leitura eventiva, há, também, a mudança de estado no Experienciador, causada, não intencionalmente, por alguém ou por algo, como nas sentenças em (39). Já a leitura estativa não possui nem Agente nem mudança de estado do Experienciador, como em (40).

(38) Nina frightened Laura deliberately / to make her go away. ${ }^{18}$

'Nina assustou Laura deliberadamente / para fazê-la ir embora'

(39) a. Nina frightened Laura unintentionally / accidentally.

'Nina assustou Laura não intencionalmente / acidentalmente'

b. The explosion / the noise / the thunderstorm frightened Laura.

'A explosão / o barulho / o trovão assustou Laura'

(40) a. John / John's haircut annoys Nina.

'João / o corte de cabelo de João irrita Nina'

b. John / John's behaviour / nuclear war frightened Nina.

'João / o comportamento de João / a guerra nuclear assustou Nina'

(ARAD, 1998, p. 181-182)

Na leitura estativa, o sujeito da oração funciona como um estímulo, e a percepção desse estímulo desencadeia um estado mental no Experienciador (sintaticamente, o objeto). Segundo Arad (1998), o desencadeamento do estado mental pelo estímulo e a percepção do estímulo pelo Experienciador não são processos controlados, ou seja, o estímulo tem como

\footnotetext{
${ }^{18}$ Com o objetivo de não gerar ambiguidade entre a leitura agentiva e a estativa nas sentenças com sujeitos humanos, Arad (1998) utiliza, nas sentenças de leitura agentiva (cf. (38)), expressões como 'deliberadamente' e orações que se referem a um propósito, como 'para fazê-la ir embora'. Já para as sentenças de leitura eventiva, usa expressões como 'não intencionalmente' e 'acidentalmente' (cf. (39a)). Essas estratégias para diferenciar as leituras agentiva e eventiva estão diretamente ligadas à semântica do argumento na posição de sujeito: Agente e Causa, respectivamente. De acordo com a autora, a propriedade que diferencia o Agente da Causa é a intencionalidade com relação à mudança de estado sofrida pelo objeto, isto é, um Agente é responsável tanto pela própria ação quanto pela mudança de estado que ele desencadeia. Já a Causa é responsável apenas pela própria ação, e não pela mudança de estado que ela produz.
} 
propriedade inerente ser o gatilho de um estado mental particular no Experienciador, o qual também não controla o estado mental que o estímulo desencadeia. Quanto ao fato de não haver mudança de estado nesse tipo de leitura, a autora observa que o Experienciador só se encontra em um determinado estado mental enquanto ele percebe (ou tem em mente) o estímulo: se o estímulo desaparece, o estado também desaparece. Na leitura estativa, portanto, o estímulo é parte inerente do evento do estado mental, diferentemente das leituras agentiva e estativa, em que o estímulo apenas desencadeia o evento do estado mental.

A relação entre as três leituras semânticas dos verbos psicológicos ExpObj e as suas respectivas propriedades pode ser esquematizada da seguinte maneira:

\section{Agente intencional Mudança de estado}

\section{no objeto}

$\begin{array}{lll}\text { Leitura agentiva } & + & + \\ \text { Leitura eventiva } & - & + \\ \text { Leitura estativa } & - & -\end{array}$

(ARAD, 1998, p. 186)

Arad (1998) constata que alguns verbos permitem apenas um tipo de leitura, como o verbo concern, em inglês, que só admite a leitura estativa, não sendo possível, por exemplo, construir um predicado que contenha uma sentença propositiva, a fim de se obter a leitura agentiva (cf. (42)). Em contrapartida, outros verbos podem permitir todas as três leituras, como frighten (cf. (38), (39) e (40b), acima).

\section{(42) Nina concerned Laura (*in order to draw her attention). \\ 'Nina preocupou Laura (*a fim de chamar a sua atenção)'}

(ARAD, 1998, p. 186)

Com relação à propriedade semântica de causação dos predicados psicológicos, Arad (1998) considera todas as leituras sendo causativas, com a ressalva de que as diferentes leituras apresentam diferentes tipos de causação: as leituras não estativas (agentiva e eventiva) são um causação ativa, pois causam uma mudança de estado, e a leitura estativa é uma causação estativa e caracteriza-se por desencadear um estado concomitante. A afirmação de 
que todas as leituras são causativas é possível de ser feita, segundo a autora, devido a evidências encontradas em línguas que possuem morfologia causativa em todos os tipos de leitura dos verbos ObjExp, como o finlandês, o hebraico e o japonês. ${ }^{19}$

As três interpretações semânticas possíveis para os predicados psicológicos também estão associadas a diferenças sintáticas entre esses predicados. Arad (1998) argumenta que a leitura estativa é a leitura psicológica típica, pois apresenta todas as propriedades sintáticas específicas aos verbos psicológicos ExpObj determinadas por Belletti e Rizzi (1988) para o italiano (não podem se ligar ao clítico reflexivo si, não podem aparecer em construções causativas, não permitem extração de objeto e permitem ligação excepcional de anafórico). Embora todas essas propriedades, chamadas na literatura de 'efeitos psicológicos', possam ser associadas à leitura estativa, os predicados com leitura agentiva não apresentam nenhuma delas. Eles comportam-se, portanto, como predicados transitivos agentivos prototípicos. Já a leitura eventiva possui um comportamento intermediário entre as duas outras leituras, pois apresenta apenas alguns dos efeitos psicológicos. Além disso, os predicados com semântica eventiva não são homogêneos, uma vez que as propriedades sintáticas a eles relacionadas variam entre as línguas.

Arad (1998) propõe, também, que as leituras não estativa e estativa diferem estruturalmente. Na estrutura não estativa, o argumento Agente ou Causa ocupa a posição de especificador de $v \mathrm{P}$, e, na estativa, o Estímulo ocupa a posição de especificador de VP, pois é o núcleo lexical $V$ que seleciona esse argumento, como ilustrado em (43a) e (43b), respectivamente:

\footnotetext{
${ }^{19}$ Arad (1998), para comprovar sua análise de que as leituras estativas dos verbos ExpObj também são causativas, fornece um exemplo do finlandês, que possui leitura estativa e apresenta morfologia causativa:

(Contexto: Ontem eu fui ao mercado de peixe, mas não comprei nada. Eles manuseiam o peixe com as mãos vazias, e )

$$
\begin{array}{llll}
\text { se } & \text { inho- } & t t i & \text { minu- } a \\
\text { that-NOM } & \text { find disgusting } & \text { CAUS } & \text { PAST-I-PART }
\end{array}
$$


(43) a.

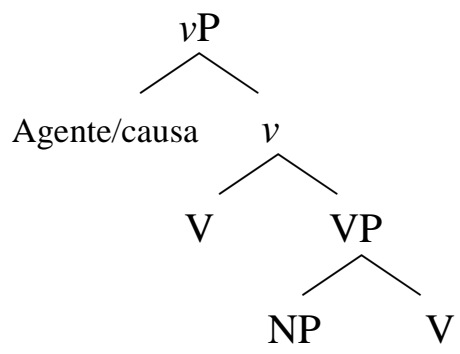

b.

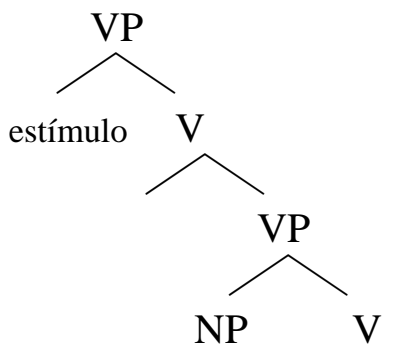

(ARAD, 1998, p. 209)

As representações formalizadas por Arad (1998), em (43), seguem o trabalho de Chomsky (1995 apud ARAD, 1998), que desenvolve a Teoria de VP-shells, proposta primeiramente por Larson (1988 apud ARAD, 1998) para os predicados bitransitivos e para os locativos. Nessa teoria, há a divisão da projeção VP em dois domínios: um domínio lexical, representado pelo VP mais baixo da estrutura, onde o argumento interno é gerado, e o VP superior (denominado de $v \mathrm{P}$ ), que contém um núcleo funcional $v$ e projeta o argumento externo. A representação da leitura não estativa, em (43a), segue o padrão da representação de verbos transitivos, possuindo um núcleo lexical e um funcional, sendo este último domínio o responsável por projetar o argumento externo, no caso, o argumento Agente ou Causa. Arad (1998) ressalta que os argumentos Agente e Causa ocupam a mesma posição sintática especificador de vP -, mas se relacionam de forma distinta com o VP. Enquanto o verbo lexical, em estruturas agentivas, seleciona o argumento externo Agente (além do argumento interno), em uma estrutura com argumento Causa, em razão de ser considerada essencialmente intransitiva, o núcleo de VP apenas projeta um argumento interno, sendo o argumento Causa inserido na estrutura diretamente na posição de especificador de vP, por meio de um processo de transitivização.

Sob uma perspectiva aspectual da estrutura, e adotando Ramchand (1997 apud ARAD, 1998), a autora assume que os argumentos relativos à informação da trajetória temporal de um evento estão restritos à posição de especificador da projeção lexical VP, mais especificamente, essa informação depende da mudança do estado do argumento interno. $\mathrm{O}$ fato de o argumento externo não participar da estrutura temporal do evento de mudança de estado, estando responsável apenas por desencadear esse evento, corrobora a determinação de que esse argumento é gerado no domínio funcional $v \mathrm{P}$, externo ao domínio lexical VP. Com relação à representação estativa, em (43b), Arad (1998) determina que o estímulo, responsável por gerar o estado do Experienciador, é projetado em um domínio lexical VP, pois, como mencionado anteriormente, por mais que o argumento na posição de objeto não sofra uma 
mudança de estado, a existência de seu estado mental depende da existência concomitante do estímulo, ou seja, o argumento estímulo, juntamente com argumento Experienciador, que se encontra em um determinado estado, participa da estrutura temporal do evento descrito pelo verbo.

A autora observa que algumas línguas, como o francês, podem realizar os predicados psicológicos ExpObj por meio da composição de um verbo leve e um complemento (nome ou adjetivo), isto é, por uma forma não incorporada, como em (44):

(44) a. mettre en colère

'colocar em raiva'

b. rendre triste

'tornar triste'

(ARAD, 1998, p. 202)

Já os verbos plenos que formam esses predicados são denominados pela autora, seguindo Bouchard (1995 apud ARAD, 1998), de formas incorporadas, as quais sofrem um processo em que um nome ou um adjetivo é incorporado a um verbo lexicalmente nulo e que pode conter um elemento preposicionado, como ilustrado em (45):

(45) a.

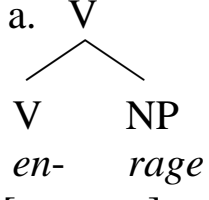

[enrager]

'enraivecer' b.

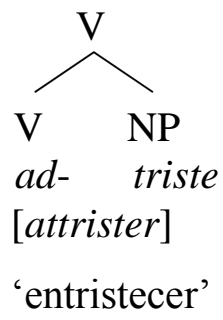

(ARAD, 1998, p. 203)

Pelo fato de Arad (1998) assumir que formas incorporadas e não incorporadas possuem a mesma estrutura de evento e a mesma estrutura sintática, ela toma como base as formas não incorporadas de verbos ExpObj para determinar as estruturas gerais dos predicados ExpObj, as quais pertencem a três tipos:

(i) locativa - Paul a mis Marie en colère (Lit.: 'Paulo colocou Maria em raiva').

(ii) dativa - This gives me a headache (Lit.: 'Isso me deu dor de cabeça'). 
(iii) causativa - Paul made Nina angry (Lit: 'Paulo fez Nina ficar com raiva').

Em todos os tipos, os predicados possuem três argumentos - um locador/doador/causador (locator/giver/causer); um locatário/alvo/causado (locatum/givee/causee); e um objeto alocado/dado (located/given object) - e, segundo a autora, possuem a seguinte representação sintática:

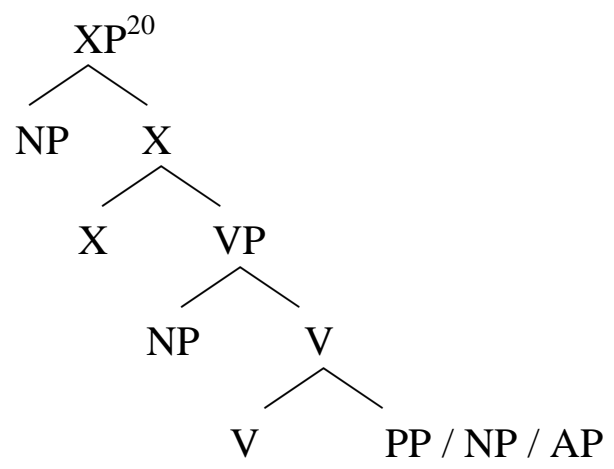

A estrutura dos três tipos de predicados é basicamente a mesma, com exceção do complemento da projeção lexical VP mais baixa, que pode ser um PP, quando for uma estrutura locativa, ou um NP, na dativa ou na causativa, que também admite um AP. Além disso, o argumento Experienciador pode estar associado a diferentes casos - ora acusativo, ora dativo - e a diferentes posições argumentais: objeto direto, objeto indireto ou um complemento de $\mathrm{P}$. O verbo leve da sentença também é responsável por determinar qual o tipo de estrutura do predicado psicológico ExpObj, por exemplo, give 'dar' forma uma estrutura dativa (give me fright 'me dar susto'), o verbo leve made 'fazer', uma causativa (The news made Nina sad - Lit.: 'As notícias fizeram Nina ficar triste'), e load 'carregar' participa de uma estrutura locativa (This loaded Nina with boredom - Lit.: 'Isso carregou [encheu] Nina com [de] aborrecimento').

Com relação, especificamente, aos predicados ExpObj locativos, Arad (1998) argumenta que eles podem apresentar duas interpretações distintas, que são resquício da alternância locativa. Em uma das interpretações, o argumento Experienciador é a 'coisa' que está localizada no estado mental, e na outra, o estado mental passa a ser localizado no

\footnotetext{
${ }^{20}$ A projeção XP refere-se tanto a uma projeção funcional $\nu \mathrm{P}$, quando a leitura do predicado for não estativa, quanto à projeção lexical VP, responsável por gerar o argumento estímulo de predicados estativos.
} 
Experienciador, que é o contêiner ou a locação. As sentenças do hebraico, em (47), exemplificam essas propriedades semânticas locativas:

(47) a. Ze hixnis oti le xarada..

this entered me into anxiety

isso colocou-me em ansiedade

'Isso me causou ansiedade'.

$($ Experienciador $=$ 'coisa'; estado mental $=$ contêiner $)$

b. Ze mile oti be ecev.

this filled me with sadness

isso encheu-me com tristeza

'Isso me entristeceu'.

$($ Experienciador $=$ contêiner; estado mental $=$ 'coisa' $)$

(ARAD, 1998, p. 206)

Além dos verbos ExpObj, Arad (1998) desenvolve uma análise para os predicados psicológicos que possuem o Experienciador na posição de sujeito (ExpSuj). Segundo a autora, esses verbos são sempre estativos e não apresentam nenhuma das propriedades sintáticas específicas dos psicológicos. Esses verbos, entretanto, assemelham-se a uma das estruturas dos predicados ExpObj, pois são, essencialmente, locativos. Nessa perspectiva, o Experienciador pode ou estar contido no estado mental ou ser o contêiner que é preenchido por um determinado estado, como ocorre no hebraico:

(48) a. Ani be xarada / acabim.

I at fear / nerves

'I feel fear / I am nervous'.

'Eu tenho medo / Eu estou nervoso'

$($ Experienciador $=$ 'coisa'; estado mental $=$ contêiner $)$

b. Yesh bi paxad (mi xatulim).

There is in me fear (of cats).

'I am afraid of cats'.

Há em mim medo (de gatos) 
'Eu tenho medo de gatos'

$($ Experienciador $=$ contêiner; estado mental $=$ 'coisa' $)$

(ARAD, 1998, p. 229)

Arad (1998) ressalta que, em algumas línguas, como no gaélico escocês, os predicados ExpSuj não são verbais, mas são expressos por meio de nomes inseridos em construções locativas, como em (49a). Essa relação locativa presente nos verbos ExpSuj é idêntica à relação expressa por locativos 'físicos', como em (49b).

(49) a. Tha eagal orm.

Be-present fear on me

'I am afraid'

'Eu estou com medo'

b. Tha Calum anns a'gharradh.

Be-present Calum in the Garden

'Calum is in the garden'.

'Calum está no jardim'

(ARAD, 1998, p. 230)

A autora observa, ainda, que alguns verbos ExpSuj são expressos por meio de uma relação de posse (cf. (50)) e que a existência de uma relação entre posse e locação é reconhecida na literatura há bastante tempo (cf. KAYNE, 1993 apud ARAD, 1998).

(50) I have a great admiration for him.

'Eu tenho uma grande admiração por ele'

(ARAD, 1998, p. 228)

Em uma comparação entre os verbos ExpSuj e os ExpObj, Arad (1998) argumenta que ambos os predicados psicológicos possuem uma natureza locativa; entretanto, essa natureza revela diferentes propriedades em cada predicado. Nos verbos ExpSuj, a locação é estativa, isto é, algo está em algum lugar. Já os verbos ExpObj exprimem uma locação não estativa, uma vez que algo é colocado em algum lugar. Esses dois tipos de relação locativa estão diretamente ligados à semântica de evento desses predicados: o verbo ExpSuj tem apenas uma 
eventualidade, que representa o estado em que se encontra o Experienciador, enquanto o verbo ExpObj é bieventual, sendo a eventualidade de percepção do estímulo (causa) a responsável pela eventualidade resultante do estado mental desencadeado pela percepção. Além disso, os verbos utilizados na formação desses predicados na forma não incorporada também expressam esse comportamento diferenciado, uma vez que, no inglês, os verbos ExpSuj são estativos, como be 'ser/estar' e have 'ter', e os ExpObj, são dinâmicos, como turn 'virar/tornar', put 'por/colocar' e give 'dar'. A mesma seleção ocorre com as preposições: verbos ExpSuj tendem a selecionar preposições estativas (por exemplo, in/at 'em') e verbos ExpObj, preposições dinâmicas (por exemplo, into/onto/to 'para').

Com relação à estrutura dos predicados ExpSuj, Arad (1998) sugere que ela possui apenas uma projeção VP e que o argumento externo (Experienciador) é gerado diretamente na posição de especificador de TP (cf. (51)), diferentemente dos predicados ExpObj, que possuem duas projeções VP, em que a projeção mais baixa é sempre um domínio lexical, e a mais alta pode ser tanto uma projeção lexical quanto uma projeção funcional, dependendo se o predicado é estativo ou não estativo (cf. (46)).

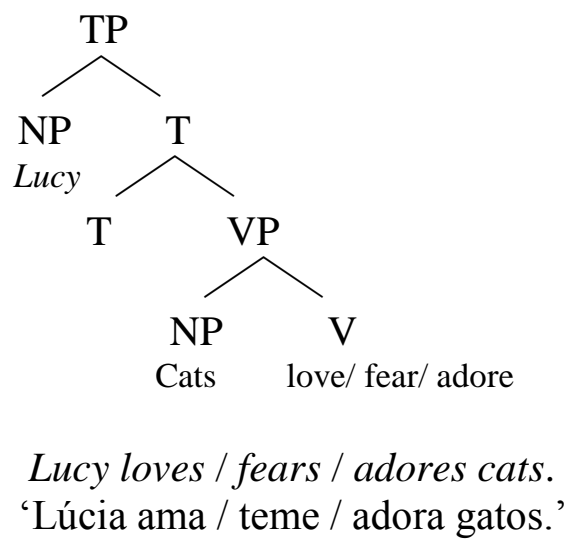

(ARAD, 1998, p. 237)

A autora argumenta que o Experienciador é inserido diretamente como argumento externo de TP, pois, além de ser externo à trajetória temporal do evento, como os argumentos externos dos predicados ExpObj eventivos, ele é estativo, o que define a sua posição em TP, e não em $v \mathrm{P}$, como ocorre com os argumentos externos eventivos.

Arad (1998) assume, ainda, que, pelo fato de os argumentos internos dos predicados ExpSuj (por exemplo, cats em (51)) denotarem uma propriedade predicativa, ou que está alocada no argumento na posição de sujeito, isto é, no Experienciador, esse argumento pode 
ser projetado como um PP locativo, como em There is in Paul a great admiration for cats 'Há em Paul uma grande admiração por gatos'.

\subsubsection{Landau (2010)}

O trabalho de Landau (2010) parte da intuição básica de que "Experienciadores são locações mentais, isto é, locativos" (Landau, 2010, p.6). Esse pressuposto, na concepção do autor, além de caracterizar a natureza cognitiva especial desses argumentos, mostra que os Experienciadores também são gramaticalmente especiais, já que acarreta, por hipótese, duas consequências gramaticais:

(52) a. Todos os Experienciadores objetos são oblíquos (ou dativos).

b. Experienciadores submetem-se à 'inversão locativa' ${ }^{21}$

(LANDAU, 2010, p. 6)

Partindo da concepção de que a realização de um trabalho em teoria sintática deve abarcar uma variedade considerável de línguas, o autor, para comprovar que os Experienciadores possuem propriedades sintáticas específicas, os chamados efeitos psicológicos (tais como a ligação excepcional de anafóricos, exemplificada anteriormente), apresenta uma série de fenômenos translinguísticos que exibem o comportamento peculiar do Experienciador. Landau (2010) analisa fenômenos presentes em diversas línguas, como inglês, grego, russo, italiano, hebraico, finlandês, faroês, entre outras, focando o contraste entre o comportamento dos Experienciadores objetos e dos objetos com outros papéis temáticos. Por exemplo, no grego, o redobro de clítico de objetos acusativos é opcional (cf. (53a)), tornando-se obrigatório apenas quando o objeto é um Experienciador (cf. (53b)).

(53) a. O Jannis (tin) ghnorise tin Maria se ena party.

The John (cl.acc) met the Mary in a party

'João conheceu Maria na festa'

\footnotetext{
${ }^{21}$ No original:

All object experiencers are oblique (or dative).

Experiencers undergo "locative inversion".
} 


\section{b. Ta epipla?*(ton) enohlun ton Petro.}

the furniture ?*(cl.acc) bother the Peter

'A mobília incomoda Pedro'

(FRANCO 1990, apud Landau, 2010, p.17)

Landau (2010) assume a classificação tripartite de Belletti \& Rizzi (1998) para os verbos psicológicos do italiano:

(54) a. Classe I (temere): Experienciador nominativo, Tema acusativo.

John loves Mary.

b. Classe II (preoccupare): Tema nominativo, Experienciador acusativo.

The show amused Bill.

c. Classe III (piacere): Tema nominativo, Experienciador dativo.

The idea appealed to Julie.

(LANDAU, 2010, p. 5- 6)

Como os predicados da classe I - verbos ExpSuj - não exibem os efeitos psicológicos que os verbos ExpObj apresentam, eles não são analisados como oblíquos, ainda que considerados metaforicamente locativos, e não são o foco de análise do trabalho do autor, o qual ressalta que a diferença entre os verbos da classe II e dos verbos da classe III, já que ambos são Experienciador objeto (ExpObj), é o fato de que os últimos são estativos, o que impossibilita o uso agentivo, e os primeiros são ambíguos entre as duas leituras - agentiva e não agentiva. Landau (2010) ressalta que os efeitos psicológicos só ocorrem com predicados psicológicos associados à leitura não agentiva.

Considerando a evidência de que geralmente locativos não sujeitos são introduzidos por uma preposição e o pressuposto de que o Experienciador é um locus mental, Landau (2010) assume que o Experienciador também deve ser complemento de uma preposição. A natureza oblíqua dos verbos da classe III do italiano (cf. (54c)) é evidente, já que o argumento Experienciador é introduzido por uma preposição manifesta; entretanto, isso não ocorre com os verbos da classe II, os quais aparentemente seriam nominais nus, o que não validaria (52a). Desconstruindo a ideia de que esses argumentos são nominais nus, o autor postula que os Experienciadores da classe II são introduzidos por uma preposição foneticamente nula - $\varnothing_{\psi \text {, }}$ responsável pela atribuição do Caso dativo. 
Restringindo-se às línguas em que a obliquidade dos Experienciadores é morfologicamente manifesta, o cenário translinguístico atestado é que, em várias línguas, os Experienciadores objetos podem ser oblíquos, enquanto, em algumas línguas, esses Experienciadores devem ser oblíquos. O espanhol, por exemplo, representa uma das línguas em que a natureza oblíqua do Experienciador é expressa pela preposição lexical:

(55) a. Ese tipo de comentarios le ${ }_{1}$ enojan a Juan . $_{1}$ that type of comments cl.dat anger to Juan

'Esse tipo de comentário irrita Ruan'

b. María lo enojo' a Juan $_{1}$.

Maria cl.acc anger to Juan

'Maria irritou Juan.'

(FRANCO 1990, apud Landau, 2010, p.17)

Os dados em (55) representam verbos que permitem a alternância dativa/acusativa na marcação do Experienciador. Na construção (55a), o Experienciador é dativo, enquanto na (55b) é acusativo. Essa distinção torna-se visível na marcação de Caso do redobro de clítico, na qual a perda do Caso dativo desse argumento está ligada ao fato de que, na sentença em que o Experienciador é marcado pelo Caso acusativo, o sujeito tem o papel temático de Agente, enquanto na primeira sentença atribui-se o papel temático de Tema a essa posição.

Algumas línguas, como o islandês, permitem que o predicado psicológico seja expresso por uma construção perifrástica, formada por um verbo leve, um nome de estado mental e um sintagma preposicionado que representa o Experienciador. Assim como atestado no espanhol, o Experienciador oblíquo está relacionado ao sujeito não agentivo (cf. (56a,b)), mas, se o sujeito é Agente, uma estrutura transitiva, na qual o Experienciador é acusativo, deve ser usada (cf. (56c)).

(56) a. Chuir a aghaidh eagla orm.

put his face fear on-me

seu rosto colocou medo em mim

'Seu rosto me assustou' 


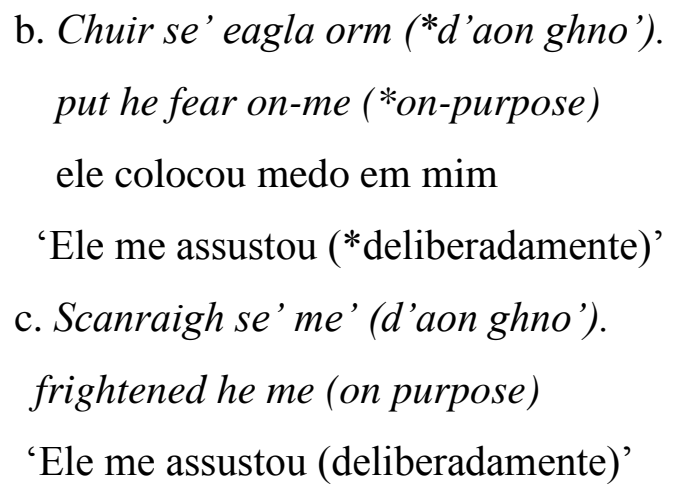

(McCLOSKEY, c. p. apud Landau, 2010, p.18)

Landau (2010) argumenta que essas línguas em que o ExpObj possui a marca dativa explícita representam um caso universal, já que cognitivamente todos os Experienciadores são locativos. Isso implica dizer que Experienciadores acusativos superficiais são, na verdade, oblíquos subjacentes. Sendo assim, Experienciadores não nominativos carregam Caso inerente. Seguindo Emonds (1985 apud LANDAU, 2010), o autor considera que a representação desse tipo de Caso na sintaxe é feita por meio de uma realização sintagmática, que, no caso dos Experienciadores objetos, é um sintagma preposicionado (PP) que domina esses argumentos. A preposição $\mathrm{P}$ do núcleo desse sintagma pode tanto ser realizada foneticamente quanto por um morfema fonologicamente nulo - $\varnothing_{\psi}$, e é ela a responsável por, universalmente, atribuir o Caso inerente. Dessa forma, o Experienciador deve exibir comportamento oblíquo/ dativo.

Para comprovar esse postulado de que Experienciadores objetos apresentam um comportamento oblíquo, Landau (2010) enumera, com foco nos verbos da classe II, as propriedades sintáticas fundamentais e específicas desses predicados, as quais sempre apresentam um Experienciador dativo. Uma delas é que, no italiano, o Experienciador da classe II pode aparecer como um dativo, associado a um clítico acusativo (cf. (57a)), o que não é possível para os objetos acusativos com outros papéis- $\theta$ (cf. (57b)).

(57) a. A Giorgio, questi argomenti non l'hanno convinto.

to Giorgio, these arguments not him-have convinced

'Esses argumentos não convenceram o Jorge'

b. *A Giorgio, la gente non lo conosce.

to Giorgio, people not him know

'As pessoas não conhecem o Jorge' 
Outra propriedade fundamental apontada pelo autor refere-se à Regra de Genitivo na Negação em construções em russo, a qual prediz a mudança do Caso acusativo de objetos diretos para Caso genitivo apenas em sentenças negativas, como em (58b), o que não pode acontecer em sentenças afirmativas, como demonstrado pela sentença (58a).

(58) a. Ja našel tzvety/*tzvetov.

I found flowers.ACC/*GEN

'Eu encontrei as flores'

b. Ja ne našel tzvety/tzvetov.

I not found flowers. ACC/GEN

'Eu não encontrei as flores'

(LANDAU, 2010, p. 23)

Os predicados psicológicos ExpObj, todavia, não seguem essa regra, pois apresentam o mesmo comportamento dos outros oblíquos: o Caso do Experienciador em construções negativas não pode ser alterado para genitivo (cf. (59)). Para Landau (2010), esse fato reforça a sua proposta de que os Experienciadores possuem Caso inerente, pois como esse Caso é marcado lexicalmente, regras sintáticas, como a de Genitivo na Negação, não podem alterar um Caso que já é marcado no léxico.

(59) * Ètot šum ne pobespokoil ni odnoj devočki.

that noise.NOM not bothered not one girl.GEN

'Esse baralho não incomodou nenhuma garota'

(LEGENDRE e AKIMOVA, 1993 apud LANDAU, 2010, p.25)

O Caso inerente dos Experienciadores, segundo Landau (2010), é frequentemente um caso quirky, mais especificamente, o autor propõe que os Experienciadores são sujeitos quirky. ${ }^{22}$ Ele assume que se podem distinguir três tipos de línguas com relação aos Casos dos sujeitos quirky:

\footnotetext{
22 "Caso quirky é o Caso inerente que pode ser realizado na posição de sujeito, e sujeito quirky é o argumento que exibe a maioria das propriedades canônicas do sujeito (exceto pela concordância), mas carrega Caso inerente." (LANDAU, 2010, p. 81).
} 
(i) Línguas em que os Experienciadores genitivos, acusativos ou dativos (realização morfológica) podem ocorrer como sujeitos quirky na posição pré-verbal, como o grego, o islandês e o faroês.

(ii) Línguas em que, nas construções com verbos da classe II, apenas Experienciadores dativos ocorrem como sujeitos. É o caso do italiano e do espanhol.

(iii) Línguas que não permitem qualquer tipo de Experienciador quirky, como o inglês, o francês e o hebraico.

A existência de línguas do tipo (i), em que os Experienciadores não nominativos podem ocupar a posição de sujeito, leva Landau (2010) a considerar que essas línguas representam o caso geral e línguas do tipo do inglês, o caso especial. Levando em consideração que o nível em que as diferenças translinguísticas são anuladas é a Forma Lógica - do inglês, Logical Form $(L F)$-, ele postula que "todos os Experienciadores são sujeitos na LF" (LANDAU, 2010, p. 86). ${ }^{23}$ Vale ressaltar que o termo 'sujeito' refere-se especificamente à posição estrutural do sujeito - [Spec, TP]. O fato de Experienciadores da classe I serem sujeitos nominativos superficiais, e o de várias línguas exibirem Experienciadores quirky na posição de sujeito são evidências positivas para esse postulado, o qual, entretanto, não é empiricamente explícito para os Experienciadores que superficialmente são realizados na posição de objeto. Utilizando a argumentação de Richards (1997 apud LANDAU, 2010) - que mostra que a possibilidade de o núcleo funcional licenciar um especificador manifesto e vários encobertos é muito comum -, e assumindo a análise inacusativa de Belletti \& Rizzi (1998) para os verbos da classe II do italiano, com algumas adaptações, o autor considera que, nos verbos ExpObj, o argumento Tema sobe para a posição de especificador de TP manifestamente, enquanto o Experienciador é alçado para um segundo [Spec, TP] na Forma Lógica. A subida do Experienciador para a posição de sujeito na LF é denominada pelo autor de 'efeito LF quirkiness'. Nesse cenário, as configurações dos verbos ExpObj na LF são esquematizadas pelas seguintes representações arbóreas:

No original: Quirky case is inherent case that can be realized in subject position; accordingly, a quirky subject is just an argument that displays most canonical subject properties (except for agreement), but bears inherent case. ${ }^{23}$ No original: "All experiencers are $L F$-subjects". 
(60) a. Verbos psicológicos eventivos

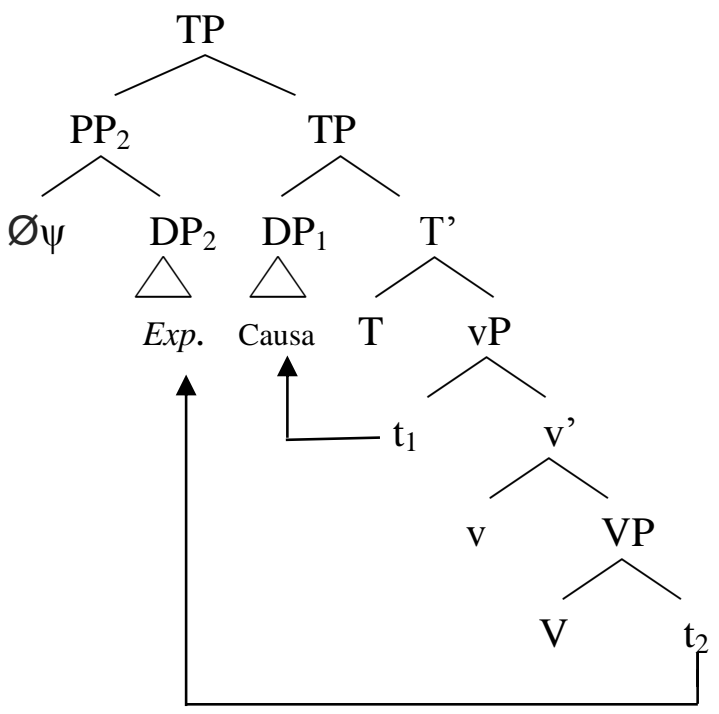

b. Verbos psicológicos estativos ${ }^{24}$

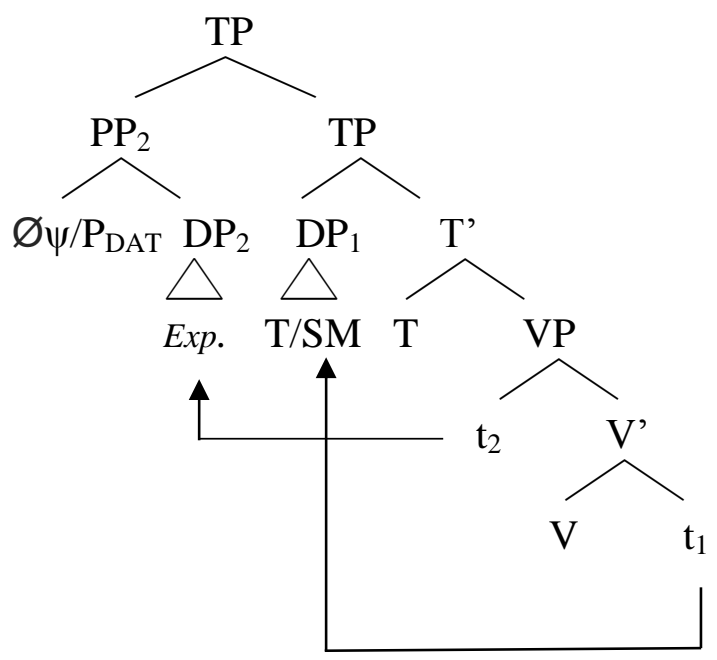

(LANDAU, 2010, p. 87-88)

O autor considera estativos todos os verbos da classe III e alguns verbos da classe II. Todos os predicados com essa leitura são considerados inacusativos e possuem dois argumentos internos. Já a outra parte dos verbos da classe II que apresentam uma leitura eventiva, desencadeada pelo argumento externo Causa, possui uma estrutura transitiva.

\footnotetext{
${ }^{24}$ A sigla T/SM refere-se ao papel temático target of emotion/subject matter proposto por Pesetsky (1995, apud Landau, 2010) para a análise dos predicados psicológicos.
} 
A natureza quirky dos Experienciadores não nominativos pode ser expressa de duas maneiras: (i) manifesta, como no islandês, em que o Experienciador sobe abertamente para o [Spec, TP]; ou (ii) encoberta, na qual o Tema nominativo é alçado de forma visível para o especificador de T, adiando para a LF a subida do Experienciador.

Landau (2010) argumenta que, como os Experienciadores são oblíquos, uma interpretação semântica surge das preposições. Para ele, todas as relações locativas, incluindo a natureza de locação mental dos Experienciadores, são codificadas pelo traço [loc], contido nas preposições, incluindo as fonologicamente nulas. $\mathrm{O}$ autor considera, ainda, que esse traço é o gatilho para o movimento do Experienciador, pois assume que $\mathrm{T}$ funciona como âncora espaço-temporal das sentenças. As relações locativas e temporais devem, portanto, formar uma relação sintática e semântica com esse núcleo funcional.

É justamente por causa do traço [loc] e de sua relação com T que Landau (2010) considera que o efeito quirky dos Experienciadores na LF se reduz à construção de inversão locativa troca de posição entre o PP locativo e o DP na sentença. Por ser esse um traço presente no núcleo do sintagma preposicionado de locativos/Experienciadores, ele passa a ser o denominador comum entre a inversão locativa e a inversão do Experienciador. Em sua proposta, o autor chega à conclusão de que verbos com leitura agentiva, e que, consequentemente, denotam mudança de estado, estão excluídos da inversão locativa. Sendo assim, apenas os verbos que se caracterizam aspectualmente por serem estados ou culminações submetem-se à inversão locativa.

\subsection{SÍNTESE DO CAPÍTULO}

Neste capítulo, apresentamos algumas análises para os predicados psicológicos, desenvolvidas, majoritariamente, no âmbito da Teoria Gerativa, com exceção da proposta de Cançado (1995). Todos os trabalhos ressaltam o comportamento especial dos verbos ExpObj, os quais submetem-se ao processo de alternância sintática, além de apresentarem outras propriedades sintáticas específicas, arroladas por Belletti e Rizzi (1988), denominadas de 'efeitos psicológicos' (cf. ARAD, 1998; LANDAU, 2010).

A partir dessas pesquisas, podemos perceber que os predicados psicológicos representam um objeto de estudo que não possui uma análise unificada. Esse cenário heterogêneo, entretanto, nos permite identificar aspectos fundamentais que devem ser 
considerados em um trabalho com esses predicados. Um desses aspectos refere-se às classes estabelecidas para esses verbos, as quais variam de acordo com os critérios considerados por cada autor: a divisão tripartite de Belletti e Rizzi (1988), também adotada por Landau (2010), parte das grades temática e de Caso dos verbos psicológicos; as quatro classes propostas por Cançado (1995), para os predicados psicológicos no português brasileiro, leva em consideração um conjunto de propriedades sintáticas e semânticas desses verbos, enquanto Naves (2005) propõe uma divisão bipartite para os verbos psicológicos no português, tomando por base o fato de o predicado admitir ou não alternância sintática; já Arad (1998) estabelece três classes para os predicados psicológicos, referentes ao tipo de leitura aspectual desses predicados. Para a nossa análise das construções perifrásticas (cf. capítulo 4), levaremos em consideração as propostas dos trabalhos para os predicados psicológicos no português: Cançado (1995) e Naves (2005).

Os trabalhos de Arad (1998) e Landau (2010) tornam-se importantes para a análise desenvolvida neste trabalho, primeiramente, pelo fato de eles estenderem suas propostas para os verbos psicológicos às construções perifrásticas dos respectivos verbos, as quais são o nosso objeto de estudo. Além disso, ambos apresentam, de formas distintas, uma análise em que os predicados psicológicos são considerados locativos, o que também faz parte da nossa investigação. Arad (1998) argumenta que a estrutura locativa é uma das possíveis para esses predicados, na qual o argumento Experienciador pode ser ou o locativo ou a 'coisa' contida no estado mental. Nessa proposta, as preposições e os verbos possuem um papel fundamental para determinar qual argumento é, semanticamente, o local no predicado.

Diferentemente de Arad (1998), Landau (2010) considera todos os Experienciadores cognitivamente locativos, embora postule que apenas os Experienciadores que ocupam a posição de objeto se configuram gramaticalmente como oblíquos (o que seria a contraparte gramatical do fato de serem cognitivamente locativos). Desenvolveremos essa hipótese no próximo capítulo, com base em trabalhos desenvolvidos na interface semântico-conceitual, associando-a à nossa investigação sobre as perífrases dos predicados psicológicos no português brasileiro. 


\section{CAPÍTULO 3}

\section{O EXPERIENCIADOR COMO LOCUS MENTAL}

Neste capítulo exploramos o pressuposto de que o argumento Experienciador dos predicados psicológicos é, cognitivamente, um locativo, isto é, um locus mental (LANDAU, 2010). Nosso objetivo é oferecer subsídios, a partir de pesquisas desenvolvidas na interface entre semântica e cognição, que justifiquem a hipótese locativa para o Experienciador. Os trabalhos discutidos neste capítulo não possuem o mesmo arcabouço teórico, entretanto, todos eles compartilham, de alguma forma, a primazia da semântica presente nas relações espaciais locativas para a proposição de análises semântico-conceituais, que se aplicam aos mais diversos campos semânticos e a distintas construções sintáticas.

Na seção 3.1, apresentamos a Teoria Semântico-Conceitual de Jackendoff (1983), responsável por propor a Hipótese das Teorias Temáticas, que prediz que as relações temáticas estabelecidas nos diferentes campos semânticos baseiam-se na relação temática existente no campo espacial. Introduzimos, na seção 3.2, o trabalho desenvolvido por Lakoff e Johnson (1999), na perspectiva da Linguística Cognitiva, que argumenta que os conceitos integrantes da estrutura de eventos são metaforicamente conceitualizados, por meio de metáforas locativas. Em 3.3, fazemos uma breve exposição, dentro também do referencial teórico da Gramática Cognitiva, da pesquisa de Huelva Unternbäumen (2015), a qual estabelece uma rede metafórica, a partir das metáforas locativas, para as construções bitransitivas que, semanticamente, correspondem à categoria de transferência de objeto. Ao longo do capítulo, tecemos considerações que correlacionam os trabalhos aqui apresentados com a hipótese de que o argumento Experienciador é locativo e encerramos com a síntese dos principais pontos do capítulo.

\subsection{A TeOria SEMÂNTICO-CONCEITUAL DE JACKENDOFF (1983)}

Em Semantics and Cognition, Jackendoff (1983) aponta o fato de a semântica ser a responsável por fazer a ligação entre a teoria da linguagem e a teoria de outras capacidades 
cognitivas, de modo que a capacidade semântica está sempre atrelada à cognição. Isso permite dizer que o estudo da semântica das línguas naturais é, por consequência, o estudo da estrutura do pensamento. Com base nessas considerações, o autor desenvolve uma teoria da estrutura conceitual, responsável pelas informações compartilhadas pela teoria linguística e por campos da cognição, como a visão e o controle motor. Essa estrutura conceitual dá origem ao mundo que é inconscientemente organizado pela mente - o mundo projetado -, e não, ao mundo real. As informações transmitidas pela linguagem, por exemplo, devem ser sobre o mundo projetado. É importante ressaltar que, para Jackendoff (1983), a estrutura conceitual e a estrutura semântica remetem ao mesmo nível de representação; dessa forma, a teoria por ele desenvolvida é uma teoria semântico-conceitual.

As unidades utilizadas na teoria para a representação da estrutura conceitual, ou imagem mental, são chamadas 'constituintes conceituais', os quais se referem a categorias ontológicas, como [OBJETO], [LUGAR], [TRAJETÓRIA], [ESTADO], [EVENTO], entre outras. ${ }^{25}$ Com relação à representação sintática da estrutura conceitual, ela é formulada tendo como base a teoria $\mathrm{X}$-barra das categorias gramaticais, que propõe que todas as grandes categorias lexicais permitem os mesmos tipos de modificação (CHOMSKY, 1970; EMONDS, 1976; JAKENDOFF, 1977 apud JACKENDOFF, 1983). Segundo o autor, o uso dessas generalizações sintáticas entre as categorias funciona como evidência para uma correlação entre as generalizações semânticas. A partir desse paralelo com o modelo X-barra, Jackendoff (1983) determina que: (i) todos os maiores constituintes sintagmáticos na sintaxe correspondem a constituintes conceituais, pertencentes às principais categorias ontológicas; (ii) o núcleo lexical $x$ desse constituinte sintagmático (nome, verbo, adjetivo, advérbio ou preposição) corresponde a uma função interna na estrutura conceitual: possui uma codificação interna com o número de argumentos necessário para completar o constituinte conceitual, sendo as posições desses argumentos preenchidas por projeções máximas, subcategorizadas pelo núcleo $x$.

Formalizando esses princípios, tem-se, por exemplo:

(1) a. The man put the book on the table.

\footnotetext{
${ }^{25}$ No original: [THING], [PLACE], [PATH], [STATE] e [EVENT].

Para distinguir uma palavra referente a uma categoria conceitual, Jackendoff (1983) escreve a palavra toda em letra maiúscula, além de representá-la entre colchetes.
} 
b. $\left[\begin{array}{l}\text { EVENT } \\ P U T\left(\left[\begin{array}{l}\text { THING } \\ T H E M A N\end{array}\right],\left[\begin{array}{l}\text { THING } \\ \text { THE BOOK }\end{array}\right],\left[\begin{array}{l}\text { PLACE } \\ \text { ON THE TABLE }\end{array}\right]\right)\end{array}\right]$

(JACKENDOFF, 1983, p. 67)

A sentença em (1a) possui, como núcleo, o verbo put 'colocar', o qual subcategoriza três argumentos: um sintagma nominal sujeito (the man), um sintagma nominal objeto direto (the book) e um sintagma preposicionado (on the table). Esses três argumentos correspondem, na estrutura conceitual, aos constituintes conceituais [THING], [THING] e [PLACE], respectivamente, os quais representam a função semântica expressa pelo verbo put. Segundo o autor, "cada categoria ontológica máxima é expressa por um determinado constituinte sintagmático máximo, dependendo da semântica do núcleo" (JACKENDOFF, 1983, p. 68). ${ }^{26}$ Na representação (1b), por exemplo, o núcleo verbal put mapeia um EVENT. Jackendoff (1983) observa que, nessa estrutura, as categorias ontológicas [THING], expressas pelos itens lexicais nucleares man e book, não subcategorizam nenhum outro constituinte máximo, portanto, são núcleos classificados como funções de zero lugares (zero-place functions). Já o núcleo on do argumento preposicionado, correspondente ao constituinte conceitual [PLACE], tem como função semântica interna a codificação de um argumento, o que resulta na subcategorização de um sintagma nominal (the table), ou seja, no mapeamento de um constituinte conceitual [THING]. Essa análise mais minuciosa do constituinte conceitual [PLACE] (2) acarreta a estrutura conceitual da sentença, ilustrada em (3).

(2)

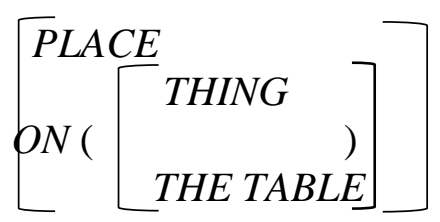

\footnotetext{
${ }^{26}$ No original: "Which major ontological category is expressed by a particular major frasal constituent depends on the semantics of the head".
} 
(3)

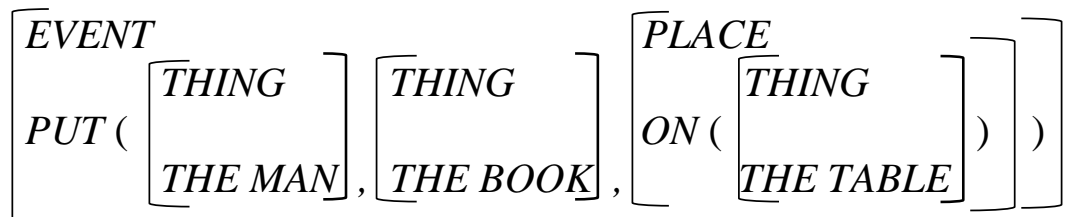

(JACKENDOFF, 1983, p. 68)

Em uma análise mais rebuscada de sintagmas preposicionados espaciais no inglês, Jackendoff (1983) constata que eles podem ser expressos, gramaticalmente, pelo que ele chama de preposições intransitivas, como here (The book is here 'O livro está aqui'), e por preposições que exigem um complemento, como em on the table 'sobre a mesa' (cf. (1a)), o qual, semanticamente, é denominado 'objeto de referência' (reference object). ${ }^{27} \mathrm{O}$ lugar de referência, expresso por todo o sintagma preposicionado, contém, portanto, o objeto de referência.

Diante das configurações gramaticais possíveis para os sintagmas preposicionados espaciais, o autor propõe que a semântica desses sintagmas, isto é, dos constituintes conceituais de lugar, $[P L A C E]$, segue a regra de representação na estrutura conceitual em (4), na qual as diferentes estruturas dos sintagmas preposicionados correspondem a diferentes conceitos de locação: preposições intransitivas são representadas por [PLACE], enquanto sintagmas preposicionados que possuem uma preposição transitiva - que expressa uma função de lugar, representada pela categoria $[$ THING] - equivalem a [PLACE-FUNCTION ([THING])], na estrutura conceitual.

(4)

$$
[\text { PLACE }] \rightarrow\left[\begin{array}{l}
\text { PLACE } \\
\text { PLACE-FUNCTION }([\text { THING }])
\end{array}\right]
$$

(JACKENDOFF, 1983, p. 162)

Sobre a função de lugar expressa pelas preposições transitivas, o autor descreve que ela impõe restrições semânticas ao seu objeto de referência. Por exemplo, a preposição in da língua inglesa requer, conceitualmente, um objeto de referência considerado uma área

\footnotetext{
${ }^{27}$ Os sintagmas preposicionados de semântica espacial referem-se a entidades de lugar (place) e de trajetória (path) do mundo projetado. Entretanto, desenvolvemos, neste trabalho, apenas a análise de Jackendoff (1983) para a estrutura conceitual da categoria ontológica $[P L A C E]$.
} 
delimitada ou um volume, enquanto a função de lugar referente à preposição on exige um objeto de referência que possua uma superfície superior.

Alternativamente à representação em (4), Jackendoff (1983) apresenta uma notação em que as categorias ontológicas aparecem subscritas dentro dos colchetes, como ilustrado em (5) pelos conceitos ontológicos $[P L A C E]$ e $[T H I N G]$ de sintagmas com preposições transitivas, que aparecem subscritos.

(5) $[$ Place $X] \rightarrow[$ Place $P L A C E-F U N C T I O N([$ Thing $Y])$

(JACKENDOFF, 1983, p. 162)

Segundo Jackendoff (1983, p. 162), em construções eventivas ou estativas com sintagmas preposicionados espaciais de lugar, a categoria $[P L A C E]$ projeta-se em um ponto ou região e, normalmente, é ocupada por [THING], como em (6a). Esse sintagma locativo, entretanto, também pode ser o local do evento ou do estado descrito pela sentença (cf. (6b)).

(6) a. John is in the room. $\rightarrow([$ THING] occupies $[$ PLACE] $)$

'João está na sala'

b. Jean ate breakfast in her bedroom.

'Jean comeu o café da manhã em seu quarto'

(JACKENDOFF, 1983, p. 163)

Desenvolvendo a análise de construções espaciais locativas, Jackendoff (1983) propõe duas estruturas conceituais distintas, uma para sentenças que expressam um [EVENTO] e outra para [ESTADO] (cf. (7) e (8), respectivamente). Para a construção dessa representação conceitual, Jackendoff (1983) utiliza, como parâmetro, sentenças com a estrutura NP V PP, nas quais, o NP refere-se ao objeto, o PP, ao lugar, e a sentença toda, à situação em que o objeto está localizado. Com o objetivo de formalizar a função semântica do NP que é o termo (algo ou alguém) sobre o qual o movimento ou a localização é afirmada, o autor, utilizando a proposta de Gruber (1965 apud JACKENDOFF, 1983), denomina esse sintagma de Tema (do inglês, theme), representado por the bird e Max, nas sentenças a seguir. O PP, como já mencionado anteriormente, contém a função 'objeto de referência'.

(7) a. [Event $\operatorname{STAY}([$ Thing $x]$, [Place $y])]$ 


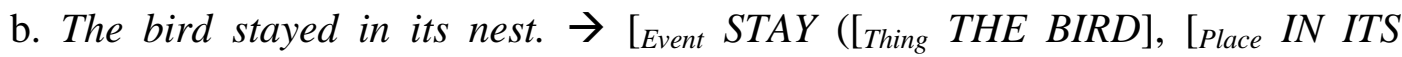
NEST])]

'O pássaro permaneceu em seu ninho'

(8) a. $[$ State $B E([$ Thing $x],[$ Place $y])]$

b. Max is in Africa $\rightarrow\left[{ }_{\text {State }} B E\right.$ ([Thing MAX], [Place IN AFRICA])]

'Max está na África'

(JACKENDOFF, 1983, p. 171-172)

Outro importante elemento das funções espaciais, destacado por Jackendoff (1983), é a noção de causação. Essa relação de causa pode ser constatada com a sentença causativa de (9b) em contraponto com a não causativa, em (9a):

(9) a. The books stayed on the shelf.

'Os livros permaneceram na prateleira'

b. Suzanne kept the books on the shelf.

'Suzana manteve os livros na prateleira'

(JACKENDOFF, 1983, p. 173)

A sentença (9b) possui um Agente (Suzanne) responsável pelo evento que também está descrito na sentença não causativa (9a). Com relação à estrutura sintática, a oração não causativa apresenta a configuração NP V PP, com o argumento Tema ocupando a posição de sujeito, assim como as outras orações espaciais de locação apresentadas aqui, enquanto a sentença causativa possui a forma NP V NP PP, em que o primeiro sintagma nominal exerce a função sintática de sujeito, e semanticamente, é o Agente, e o segundo NP é o Tema e aparece como objeto direto. Quanto à estrutura conceitual das sentenças causativas, Jackendoff (1983) propõe a representação geral em (10a), sendo a representação referente à sentença (9b), dada em (10b):

(10) a. [Event $\operatorname{CAUSE}([$ Thing $\mathrm{x}]$, [Event $\mathrm{y}])]$

b. [Event CAUSE ([Thing SUZANNE], [Event STAY ([Thing BOOKS], [Place ON SHELF])])] 
Essa representação mostra que o evento descrito na sentença (9a) é realizado como o evento subordinado na estrutura causativa. Jackendoff (1983) ressalta, ainda, que, na estrutura semântica de CAUSE, o NP sujeito não é, necessariamente, um Agente volitivo, visto que, em sentenças como The wind pushed Sim into the room 'O vento empurrou Sim para dentro do quarto', o argumento Agente (the wind) é um ser inanimado e, portanto, não pode agir intencionalmente (JACKENDOFF, 1983, p. 175).

Essa elaborada análise de construções com semântica espacial e de seus respectivos sintagmas preposicionados e o estabelecimento de uma proposta de estrutura conceitual para essas construções têm o objetivo de ampliar e formalizar a hipótese de Gruber (1965 apud JACKENDOFF, 1983), que propõe que as relações temáticas presentes nos campos espaciais - locação e movimento - estendem-se aos mais diversos campos semânticos. Jackendoff (1983), então, esquematiza essa hipótese, denominada Hipótese das Relações Temáticas, da seguinte maneira:

\section{(11) Hipótese das Relações Temáticas $\left(\right.$ HRT) ${ }^{28}$}

Em qualquer campo semântico de [EVENTOS] ou [ESTADOS], as principais funções de evento, estado, trajetória e lugar são um subconjunto daquelas utilizadas para as análises de movimento e de locação espacial. Os campos diferem apenas de três maneiras:

a. que tipos de entidades podem aparecer como Tema;

b. que tipos de entidades podem aparecer como objeto de referência;

c. que tipo de relação assume o papel de locação no campo de expressões espaciais.

(JACKENDOFF, 1983, p. 188)

Inspirado na reivindicação psicológica de que a mente não fabrica conceitos abstratos sem motivos, e sim adapta o maquinário já existente para o desenvolvimento do indivíduo e da espécie, Jackendoff (1983) argumenta que a aplicação da organização de conceitos de

\footnotetext{
28 No original:

Thematic Relations Hypothesis (TRH)

In any semantic field of [EVENTS] and [STATES], the principal event-, state-, path-, and place-functions are a subset of those used for the analysis of spatial location and motion. Fields differ in only three possible ways:

a. what sorts of entities may appear as theme;

b. what sorts of entities may appear as reference objects;

c. what kind of relation assumes the role played by location in the field of spatial expressions.
} 
espaço físico a outros campos semânticos é possível, sendo necessário apenas adaptar e restringir os conceitos ao novo campo semântico. $\mathrm{O}$ autor, então, aplica a generalização em (11), baseada nos conceitos do campo espacial, a diferentes campos semânticos: campo temporal, campo de posse, campo circunstancial e campo identificacional.

Para definir os critérios de aplicação da Hipótese das Relações Temáticas aos novos campos semânticos, Jackendoff (1983) compara sintagmas preposicionais de outros campos semânticos com sintagmas preposicionais locativos. Por exemplo, em (12), o autor apresenta exemplos de sintagmas preposicionais temporais, e, em (13), os locativos:

(12) a. at 6:00

b. from Tuesday to Thursday

c. in 1976

d. on my birthday

(13) a. at the corner

b. from Denver to Indianapolis

c. in Cincinnati

d. on the table

(JACKENDOFF, 1983, p. 189, grifos nossos)

A partir dos dados acima e da comparação de expressões temporais (p. ex., In 1976, Max met a cockroach) com expressões locativas (p. ex., In Cincinnati, Max met a cockroach), o autor afirma que ambos os sintagmas, temporal e locativo, além de apresentarem um importante paralelo no uso das preposições, conectam-se às sentenças da mesma maneira. Jackendoff (1983) ressalta, ainda, que, no campo semântico de tempo, são os [EVENTOS] e os [ESTADOS], e não os [OBJETOS], que estão localizados no tempo. Diante dessas evidências, e levando em consideração os critérios estabelecidos na Hipótese das Relações Temáticas, o campo temporal é definido como: 
(14) Campo temporal: ${ }^{29}$

a. [EVENTOS] e [ESTADOS] aparecem como Tema.

b. [TEMPO] aparece como objeto de referência.

c. O tempo da ocorrência desempenha o papel de localização.

(JACKENDOFF, 1983, p. 189)

O forte paralelismo semântico existente entre expressões locativas e temporais, identificado pelo uso dos mesmos verbos para expressar determinados significados, também se estende à estrutura conceitual. Por exemplo, a conceitualização da sentença temporal causativa em (15a) é formalmente realizada a partir das funções espaciais (cf. (15b)).

(15) a. We kept the meeting at 6:00

'Nós mantivemos o encontro às $6 \mathrm{~h}$ '

b. [Event $C A U S E\left(\left[_{\text {Thing }} W E\right],{ }_{\text {Event }} S T A Y_{\text {Temp }}\left(\left[_{\text {Event }}\right.\right.\right.$ MEETING], [Place $A T_{\text {Temp }}\left(\left[_{\text {Time }}\right.\right.$ 6:00])])])])]

(JACKENDOFF, 1983, p. 191)

Em síntese, Jackendoff (1983) acredita que a Hipótese das Relações Temáticas pode ser aplicada a todos os campos semânticos e a eleição do campo espacial como referência para os demais campos é devida ao fato de ele ter grande suporte de diversos campos cognitivos não linguísticos e à constatação de que "de uma perspectiva evolucionária, a organização espacial teve de existir muito antes da linguagem" (JACKENDOFF, 1983, p. 210). ${ }^{30}$ Para que essa análise temática seja estabelecida, é indispensável o uso de noções como [EVENTO], [LUGAR], [TRAJETÓRIA], entre outras, ou seja, é imprescindível a formalização das categorias ontológicas. Essa prerrogativa ratifica o pressuposto de as estruturas conceitual e semântica pertencerem ao mesmo nível de representação e, portanto, a de que uma teoria da estrutura semântica da linguagem é, também, uma teoria da estrutura do pensamento. Jackendoff (1983) argumenta, ainda, que a hipótese, por ele desenvolvida, para a estrutura temática não funciona como uma metáfora espacial, como adotado pela linguística cognitiva,

\footnotetext{
${ }^{29}$ No original:

Temporal field:

a. [EVENTS] and [STATES] appear as theme.

b. [TIMES] appear as reference object.

c. Time of occurrence plays the role of location.

${ }^{30}$ No original: From an evolutionary perspective, spatial organization had to exist long before language.
} 
visto que metáforas podem ser usadas para efeitos artísticos, diferentemente do que ocorre com as relações temáticas. A estrutura temática é considerada, portanto, "uma organização abstrata que pode ser aplicada, com especialização adequada, a qualquer campo" (JACKENDOFF, 1983, p. 210). ${ }^{31}$

A teoria desenvolvida por Jackendoff (1983) possibilita uma análise cuidadosa dos sintagmas espaciais preposicionados, a fim de estabelecer uma estrutura conceitual/temática das relações espaciais. A Hipótese das Relações Temáticas, que pode ser aplicada a diferentes campos semânticos, nos abre a possibilidade de incluir os verbos psicológicos nessa análise. Dessa forma, as relações temáticas estabelecidas para os argumentos dos predicados psicológicos, dos quais o Experienciador faz parte, estão relacionadas à semântica locativa. Além disso, nas estruturas perifrásticas psicológicas causativas, o Experienciador é um argumento preposicionado, o que nos permite estender a análise desenvolvida por Jackendoff (1983) para os sintagmas preposicionados, os quais são conceitualizados como [LUGAR], aos argumentos Experienciadores dos predicados psicológicos. Nessa perspectiva, esses argumentos são conceitualizados como [LUGAR], assim como proposto por Landau (2010).

\subsection{A CONCEITUALIZAÇÃo METAFóRICA DE LAKOFF E JOHNSON (1999)}

O trabalho de Lakoff e Johnson (1999) parte de três importantes descobertas da ciência cognitiva sobre a natureza da mente: “(i) a mente é inerentemente corporificada; (ii) o pensamento é, em sua maioria, inconsciente; e (iii) conceitos abstratos são, em grande parte, metafóricos" (op. cit., p. 14). ${ }^{32}$ Essas três ideias centrais, segundo os autores, contribuem para a construção de uma nova filosofia, pois representam a mudança de importantes pressupostos da filosofia tradicional, entre eles, a mudança da natureza da razão - componente responsável por definir os seres humanos e que lhes possibilita, entre diversas funções, realizar inferências lógicas e entender a si mesmos, aos outros e ao mundo. A grande mudança no entendimento da razão está no fato de ela passar a ser considerada como sendo corporificada, ou seja, ela é resultado "da natureza dos nossos cérebros, dos corpos e de experiências corporais [...], e os mesmos mecanismos cognitivos e neurais que nos permitem perceber e nos movimentar

\footnotetext{
${ }^{31}$ No original: [...] abstract organization that can be applied with suitable specialization to any field [...].

${ }^{32}$ No original: The mind is inherently embodied; Thought is mostly unconscious; Abstract concepts are largely metaphorical.
} 
também criam nossos sistemas conceituais e nossos modelos de razão" (LAKOFF e JOHNSON, 1999, p. 15). ${ }^{33}$

O conceito adotado por Lakoff e Johnson (1999, p. 22) para o termo 'cognitivo', consonante ao estabelecido pela ciência cognitiva, refere-se a "qualquer tipo de operação ou estrutura mental que pode ser estudada em termos precisos". ${ }^{34}$ Nessa abordagem, são cognitivas, por exemplo, as estruturas e/ou operações relacionadas à linguagem, ao pensamento, às emoções, aos sistemas conceituais, à percepção e à razão. Aspectos do sistema sensório-motor também se caracterizam como cognitivos, na visão dos autores, visto que contribuem para a capacidade humana de conceitualizar e de raciocinar. Eles ressaltam que, com essa configuração, as operações cognitivas são amplamente inconscientes. Nesse sistema cognitivo inconsciente, estão incluídas todas as operações cognitivas automáticas e o conhecimento implícito, os quais se configuram como sistemas conceituais, responsáveis por moldar os aspectos da experiência.

A partir da premissa de que todo ser vivo categoriza, na maioria das vezes, de forma inconsciente, Lakoff e Johnson (1999) argumentam que a formação de categorias é resultado da interação das mentes e dos corpos, isto é, da corporificação da mente, com o funcionamento do mundo. Dessa forma, as categorias são parte da experiência do ser humano. Segundo os autores, em razão da composição biológica dos seres humanos em seres neurais, é possível caracterizar mentalmente as categorias, sendo os conceitos, definidos como estruturas neurais, os responsáveis pela conceitualização das categorias e pelo modo como raciocinamos sobre elas.

Considerando a imensidão e a riqueza da vida mental subjetiva humana, Lakoff e Johnson (1999) afirmam que grande parte da maneira com que as experiências subjetivas, como as emoções, são conceitualizadas tem origem em domínios sensório-motores, ou seja, em domínios diferentes do da experiência subjetiva. O mecanismo cognitivo usado para essas conceitualizações é a metáfora conceitual, uma vez que "a metáfora permite que imagens mentais convencionais de domínios sensórios-motores sejam usadas por domínios de experiência subjetiva" (LAKOFF e JOHNSON, 1999, p. 50). ${ }^{35}$ Os autores argumentam,

\footnotetext{
${ }^{33}$ No original: [...] arises from the nature of our brains, bodies, and bodily experience. [...] The same neural and cognitive mechanisms that allow us to perceive and move around also create our conceptual systems and modes of reason.

${ }^{34}$ No original: "[...] any kind of mental operation or structure that can be studied in precise terms."

35 No original: Metaphor allows conventional mental imagery from sensorimotor domains to be used for domains of subjective experience.
} 
ainda, que são raros os casos de experiências subjetivas que não são conceitualizadas metaforicamente e que as metáforas conceituais são amplamente encontradas no pensamento e na linguagem, pois elas funcionam como mapeamentos dos domínios conceituais. Uma das maneiras possíveis de conceitualização das categorias humanas são as metáforas espaciais, considerando-as contêineres/recipientes, os quais se caracterizam por possuírem um interior e um exterior e por serem delimitados por fronteiras. Lakoff e Johnson (1999) consideram os conceitos de relações espaciais os elementos centrais do sistema conceitual.

Sendo a metáfora a principal responsável pela conceitualização das experiências subjetivas, os autores apontam para o fato de a aquisição de metáforas, mais especificamente de metáforas primárias, ser um processo natural, automático e inconsciente. Essas metáforas são construídas a partir da ligação de diferentes domínios do cérebro - o domínio de experiências sensório-motoras e o domínio dedicado às experiências subjetivas. Cada metáfora pode, também, ser decomposta, levando-se em consideração esses dois domínios. Por exemplo, uma das metáforas primárias proposta por Lakoff e Johnson (1999) é a de que 'Estados são locações', a qual possui a seguinte representação:

(16) Estados são locações ${ }^{36}$

Julgamento subjetivo: um estado subjetivo

Experiência sensório-motora: estar em uma região de espaço limitado

Exemplo: "Eu estou perto de estar em uma depressão [...]."

Experiência primária: Experimentar um certo estado como correlato a uma certa locação (e.g., Sentir-se seguro na cama.)

(LAKOFF e JOHNSON, 1999, p. 56)

Em trabalho anterior - Metáforas da vida cotidiana, Lakoff e Johnson (2012 [1986]) trazem o pressuposto de que o sistema conceitual humano é fundamentalmente metafórico. Eles ressaltam que a linguagem apresenta importantes evidências do funcionamento desse sistema, por exemplo, o fato de que podemos dizer que a sentença Eu estou perto de estar em

\footnotetext{
${ }^{36}$ No original:

States are locations

Subjective judgment: A subjective state

Sensorimotor experience: Being in a bounded region of space

Example: "I'm close to being in a depression and the next thing that goes wrong will send me over the edge."

Primary experience: Experiencing a certain state as correlated with a certain location (e.g., being cool under a tree, feeling secure in bed).
} 
uma depressão, por conter expressões linguísticas relacionadas às relações espaciais - perto de e em -, exemplifica a metáfora Estados são locações, mas também ilustra a natureza espacial dos sistemas conceituais em geral.

Diante da descoberta de Narayanan (1997, apud Lakoff e Johnson, 1999) de que uma mesma estrutura neural é responsável tanto pelo controle motor quanto por caracterizar a estrutura conceitual dos eventos linguísticos, Lakoff e Johnson (1999) assumem a proposta do autor para a representação de um esqueleto único, responsável pela concepção da estrutura geral de evento, ou seja, o mesmo esqueleto para a estrutura aspectual de eventos e para a estrutura de esquemas corporais:

(17) Estrutura de conceitos de eventos ${ }^{37}$

Estado Inicial: Tudo o que é necessário para o evento estar satisfeito.

Início: O processo inicial para o evento

Término do início: $O$ término do processo inicial e o começo do processo principal

Processo Principal: Aspectos centrais do evento

Interrupções possíveis: Interrupções do processo principal

Continuação possível ou Repetição: A perpetuação ou repetição do processo principal

Estado Resultante: O estado resultante do processo principal

(LAKOFF e JOHNSON, 1999, p. 159)

$\mathrm{Na}$ proposta dos autores, os conceitos centrais da filosofia, isto é, aqueles que são imprescindíveis para a construção do conhecimento geral, como estado, causação, ação, evento e mudança, são considerados conceitos de estrutura de evento. Esses conceitos também são conceitualizados metaforicamente, e as metáforas resultantes desse processo consideradas universais - surgem da experiência corporal cotidiana. Com relação à

\footnotetext{
37 No original:

Initial State: Whatever is required for the event is satisfied

Start: The starting up process for the event

End of Start: The end of the starting up process and the beginning of the process main

Main Process: The central aspects of the event

Possible Interruptions: Disruptions of the main process

Possible Continuation or Iteration: The perpetuation or repetition of the main process

Resultant State: The state resulting from the main process
} 
composição metafórica dos conceitos de evento e de causa, Lakoff e Johnson (1999) argumentam que ela tem origem em dois tipos fundamentais de metáfora: metáforas de estrutura de evento de objeto e metáforas de estrutura de evento de locação. Considerando esse último tipo de metáfora - as locativas -, os eventos podem ser conceitualizados como locações. Nesse cenário, as metáforas primárias passam a ser caracterizadas por propriedades específicas de lugares físicos. Por exemplo, uma das metáforas primárias locativas é 'causação é movimento forçado (de uma locação para outra) ${ }^{38}$ Essa metáfora conceitualiza abstratamente o conceito prototípico de causação, a partir de propriedades locativas, visto que se refere à causa como sendo um movimento que ocorre entre lugares, isto é, levando-se em consideração a metáfora 'estados são locações', causação é a mudança de um estado para o outro. Com relação a esta última metáfora, ela é definida, também, como 'interiores de regiões delimitadas em um espaço', ou seja, os estados passam a ser conceitualizados como contêineres. Lakoff e Johnson (1999) apontam para o fato de essas metáforas locativas consistirem em um mapeamento entre um domínio de origem - domínio de movimento no espaço - e um domínio alvo - domínio de eventos. A partir dessa estrutura, a metáfora 'estados são locações (interiores de regiões delimitadas em um espaço)' possui o seguinte mapeamento:

\section{Locações $\rightarrow$ Estados}

(LAKOFF e JOHNSON, 1999, p. 163)

Lakoff e Johnson (1999) afirmam que não é possível conceituar um estado como não sendo um local, isto é, sem as propriedades de uma região delimitada no espaço. Questionam, por exemplo, como se poderia conceitualizar um estado sem as noções de interior, de exterior e de fronteira. De acordo com os autores, há evidências que corroboram essa conceitualização metafórica dos estados. Uma delas refere-se ao uso polissêmico de expressões como em, fora, beira, entre outras, as quais, além de possuírem um sentido espacial, também estão relacionadas a um sentido relativo a estados, conforme demonstram os dados em (19). Em uma análise semelhante, como vimos anteriormente (cf. subseção 2.3.1), Arad (1998) aponta

\footnotetext{
${ }^{38} \mathrm{O}$ conceito prototípico de causação refere-se à aplicação volitiva de força física em algum objeto, resultando em mudança física ou em movimento. Esse conceito pode sofrer algumas variações, entre elas: (i) movimento forçado de um objeto por um outro; (ii) causação indireta; (iii) causação via um agente intermediário; e (vi) causação permitida; etc.
} 
que uma das interpretações possíveis para os predicados psicológicos é a de que o estado mental é o contêiner ou local em que o Experienciador se encontra.

(19) a. He's in a deep depression.

'Ele está em uma depressão profunda'

b. He's on the edge of madness.

'Ele está à beira da loucura'

(LAKOFF e JOHNSON, 1999, p. 163, grifos nossos)

As palavras destacadas nessas sentenças representam as expressões polissêmicas. Em (19a), 'estar em uma depressão profunda' significa dizer, conceitualmente, que se está no interior de um determinado espaço, no caso, no interior de um determinando estado. Além disso, 'profunda' indica que o determinado espaço tem diversas dimensões, como a dimensão vertical. Ou seja, 'estar no estado de depressão profunda' refere-se ao fato de que esse estado tem uma dimensão vertical e que se está distante das fronteiras que limitam o estado, estando, portanto, longe de estar fora da depressão. Quanto a (19b), por sua vez, a expressão 'à beira' faz referência à fronteira de um estado, isto é, indica que se está no exterior, muito próximo do limite de passar ao interior desse estado, no caso, da loucura.

Outra evidência para a conceitualização metafórica dos estados em locais, apontada pelos autores, é denominada evidência inferencial, a qual é constatada a partir de pares de inferências, conforme apresentado em (20) a (23) abaixo, nos quais, a primeira refere-se a regiões delimitadas no espaço, enquanto a segunda é uma inferência de estados, correspondente ao primeiro membro do par:

(20)a. Se você está em uma região delimitada, você não está fora dessa região delimitada. ${ }^{39}$

\footnotetext{
${ }^{39}$ No original:

If you're in a bounded region, you're not out of that bounded region.

If you're in a state, you're not out of that state.

If you're out of a bounded region, you're not in that bounded region.

If you're out of a state you're not in that state.

If you're deep in a bounded region, you are far from being out of that bounded region.

If you're deep in a state, you are far from being out of that state.

If you are on the edge of a bounded region, then you are close to being in that bounded region.

If you are on the edge of a state, then you are close to being in that state.
} 
b. Se você está em um estado, você não está fora desse estado.

(21) a. Se você está fora de uma região delimitada, você não está nessa região.

b. Se você está fora de um estado, você não está nesse estado.

(22) a. Se você está profundo em uma região delimitada, você está longe de estar fora dessa região delimitada.

b. Se você está profundo em um estado, você está longe de estar fora desse estado.

(23) a. Se você está na beira de uma região delimitada, então você está perto de estar nessa região delimitada.

b. Se você está na beira de um estado, então você está perto de estar nesse estado.

(LAKOFF e JOHNSON, 1999, p. 164)

Com base nessas considerações, Lakoff e Johnson (1999) concluem que tanto a evidência das expressões polissêmicas como a evidência dos pares de inferências atestam o mapeamento em (18), sendo importante ressaltar que a direção do mapeamento metafórico é das regiões delimitadas no espaço para os estados, como mostrado pelas evidências.

Como mencionado anteriormente, os eventos caracterizam-se por uma natureza dual, pois, além de serem conceitualizados como locações, também podem ser conceitualizados em termos de objetos. Nesse cenário, Lakoff e Johnson (1999) indicam que a metáfora locativa 'Estados são locações' tem como par a metáfora de estrutura de evento de objeto 'Atributos são possessões', representadas, respectivamente, por (24) e (25): ${ }^{40}$

${ }^{40}$ Os dados trazidos por Lakoff e Johnson (1999, p. 176) são:

a) Harry's in trouble. (States Are Locations)

b) Harry has trouble. (Attributes Are Possessions).

Optamos por não usar essas sentenças, pois, no português, a palavra trouble recebe traduções distintas em cada oração: 'apuro' e 'problema', respectivamente, resultando nas sentenças (i) Harry está em apuros; e (ii) Harry tem problemas. Há, ainda, a possibilidade de se manter a tradução 'problema' para a sentença (a), para isso, a preposição 'em' teria de ser substituída por 'com': 'Harry está com problemas'. Essa mudança, entretanto, parece gerar, também, uma mudança na maneira de se conceitualizar o evento: deixa de ser conceitualizado como locação e passa a ser conceitualizado em termos de posse. Nessa perspectiva, 'problemas', que antes era um locativo (estado), torna-se um atributo, que está localizado em 'João'. Ressaltamos que optamos por utilizar a forma plural nas traduções para 'trouble' - 'apuros' e 'problemas' - pelo fato de essa forma nos soar mais natural nas sentenças em que ocorre. 
(24) João está em uma depressão. (Estados são locações)

(25) João tem depressão. (Atributos são possessões)

Em (24), 'depressão' é conceitualizada como uma locação, enquanto, em (25), é um objeto. Dessa forma, na primeira sentença, segundo os autores, 'João' é uma figura e 'depressão' representa o cenário em que a figura está alocada. Já na segunda, a 'depressão' é a figura, que se situa em relação a 'João', que é o local. Em resumo, dependendo da conceituação metafórica do evento, depreendida a partir a estrutura da sentença, o nome ‘depressão’ pode tanto ser um estado e, consequentemente, é uma locação conceitual, ou ser um atributo, que conceitualmente é um objeto de que se pode ter posse.

Os dados (24) e (25) ilustram duas construções possíveis para o objeto de estudo que investigamos nessa pesquisa, os predicados psicológicos, visto que a expressão 'depressão' é a nominalização do verbo psicológico 'deprimir'. Mais especificamente, nosso trabalho, desenvolve uma análise para as construções psicológicas perifrásticas (verbo leve + nominalização), como apresentado em (25), em que ‘tem depressão' se enquadra nesse tipo de construção. Como indicado anteriormente, a sentença (25) é conceitualizada a partir de metáforas eventivas de objetos, sendo a metáfora 'Atributos são possessões' uma das responsáveis pela conceitualização. Nesse cenário, o argumento 'João' é, metaforicamente, o lugar em que a 'depressão' se encontra, fato esse que corrobora o pressuposto de Landau (2010), pois 'João' é o argumento Experienciador que é, conceitualmente, o locus mental do predicado.

Partindo de uma análise mais apurada das construções acima, percebemos que a composição sintática dos itens lexicais é determinante para a conceitualização da estrutura como um todo, por exemplo, ambas as sentenças (24) e (25) compartilham as expressões 'João' e 'depressão', as quais, entretanto, apresentam análises conceituais distintas em cada sentença. Essas evidências colocam os verbos e as preposições como elementos fundamentais para determinar a conceitualização do evento. Em (24), especificamente, a presença da preposição 'em' permite a conceitualização locativa da nominalização 'depressão', porque essa preposição introduz expressões de lugares físicos em eventos locativos prototípicos. Agora, essa mesma sentença, apenas com a troca da preposição 'em' por 'com' - 'João está com depressão' - apresenta uma nova conceitualização, em termos de possessão, o que acarreta a conceitualização de 'João' como o lugar, ou seja, a análise conceitual dessa 
sentença passa a ser igual à de (25), que não possui uma preposição, mas contém o verbo 'ter', que, assim como a preposição 'com', exibe uma leitura de posse.

Ressaltamos que, nas estruturas perifrásticas estudadas neste trabalho - causativas (cf. (26)) e não causativas (cf. (27), a seguir) -, o argumento Experienciador é conceitualizado como um lugar. Nas causativas, esse argumento é introduzido pela preposição 'em', o que lhe torna, metaforicamente, um locus mental, e nas não causativas, assim como em (25), o Experienciador também é um locativo, visto que a sentença é conceitualizada a partir da metáfora eventiva de objeto 'Atributos são possessões', a qual determina que o atributo 'preocupação' é uma posse do argumento 'a população', ou seja, está metaforicamente localizado na 'população'.

(26) A crise política causa muita preocupação na população.

(27) A população tem muita preocupação (com a crise política).

Em uma primeira impressão, o fato de as estruturas perifrásticas com Experienciador na posição de sujeito (cf. (27)) poderem ter uma conceitualização realizada por metáforas de estrutura de evento de objeto, e não por metáforas locativas, poderia não ser interessante para pensarmos a hipótese de os Experienciadores serem locativos (LANDAU, 2010), porém, como já explanado, o argumento Experienciador é, em ambas as análises, conceitualmente um lugar.

\subsection{A ESTRUTURA CONCEITUAL DA CATEgoria de TranSFERÊNCIA DE OBJETO - HuElVA UNTERNBÄUMEN (2015)}

A pesquisa de Huelva Unternbäumen (2015), baseada nos princípios da gramática cognitiva, tem como objeto de estudo o polo semântico de diferentes construções bitransitivas da categoria semântica de transferência - que constituem um predicado com três argumentos, geralmente rotulados na literatura de Agente, Paciente e Tema -, como as sentenças a seguir: 
(28) a. Paga oitenta e três reais para o peão.

b. Eu dou esta garrafa para o senhor João.

c. O vizinho deu o lote para o filho dele.

(HUELVA UNTERNBÄUMEN, 2015, p.70-71)

O autor demonstra que a estrutura semântica dessas construções se manifesta como uma matriz de domínio complexo, visto que consiste em um conjunto de metáforas conceituais, interligado pelo mecanismo cognitivo de integração conceitual (mechanism of blending). ${ }^{41}$

Huelva Unternbäumen (2015) analisa a categoria semântica prototípica de Transferência de Objeto, a qual se refere ao processo de uma pessoa transferir um objeto a outra pessoa, e argumenta que esse ato de transferência representa, cognitivamente, uma categoria básica da conceitualização humana e, portanto, tem uma origem metafórica, no sentido de que surge como uma metáfora primária (LAKOFF e JOHNSON, 1999; GRADY, 2005; GIBBS, 2005 apud Huelva Unternbäumen, 2015). As metáforas primárias são definidas como "metáforas que possuem uma base empírica, independente e direta" (HUELVA UNTERNBÄUMEN, 2015; p. 68), sendo que a integração de várias metáforas primárias resulta na criação de metáforas complexas. ${ }^{42}$

Segundo Huelva Unternbäumen (2015), a estrutura conceitual da Transferência de Objeto abrange as seguintes metáforas primárias: Pessoas são locações; Mudanças são movimentos; Causas são forças; Causação é movimento forçado; Controlar é ter nas mãos de um; Perda e aquisição de controle é mudança de mãos. Essas metáforas são submetidas ao processo complexo de integração, e compõem-se primeiramente em pares, formando metáforas complexas: Transferência é movimento de um agente para um recipiente; Transferência é movimento forçado; Transferência é perda e aquisição de controle físico. Em seguida, essas metáforas complexas integram-se entre si, dando origem à estrutura conceitual total da Transferência de Objeto, a qual tem como resultado a seguinte rede metafórica:

\footnotetext{
${ }^{41} \mathrm{O}$ mecanismo de integração (ou mecanismo de blending) é o mecanismo cognitivo responsável pela integração metafórica, que, a partir da integração de elementos de pelo menos dois espaços mentais (espaço fonte e espaço alvo), forma o terceiro espaço ('blend'). Sucintamente, esse processo cria a relação entre elementos dos espaços fonte e alvo, isto é, organiza pares de metáforas primárias, que formam as metáforas complexas da estrutura conceitual de algum determinado conceito (por exemplo, o conceito de Transferência).

${ }^{42}$ No original: [...] metaphors that have a direct, independent, experiential base.
} 
(29) TRANSFERÊNCIA DE OBJETO ${ }^{43}$

TRANSFERÊNCIA É MOVIMENTO DE UM AGENTE PARA UM RECIPIENTE

- Pessoas são locações

- Mudanças são movimentos

TRANSFERÊNCIA É MOVIMENTO FORÇADO

- Causas são forças

- Causação é movimento forçado

TRANSFERÊNCIA É PERDA E AQUISIÇÃO DE CONTROLE FÍSICO

- Controlar é ter nas mãos de um;

- Perda e aquisição de controle é mudança de mãos.

(HUELVA UNTERNBÄUMEN, 2015, p. 72)

A metáfora primária Pessoas são locações - integrante da metáfora complexa Transferência é movimento de um agente para um recipiente - representa um uso bastante documentado na construção do conceito de posse. Segundo Heine e Kuteva (2007 apud HUELVA UNTENRBÄUMEN, 2015), três esquemas conceituais dos cinco existentes na raiz da expressão de posse das línguas do mundo são de natureza espacial: Y em X (localização), Y de X (origem), Y para X (direção), sendo o possuidor, elemento X, considerado o locus na respectiva relação espacial. Huelva Unternbäumen (2015) argumenta que essa metáfora permite conceber uma pessoa como: (i) uma posição, isto é, como ponto no espaço que pode estar relacionado a outros pontos, o que permite formar os conceitos de movimento (entre dois pontos) e de trajetória (de um ponto para o outro); e (ii) um espaço circunscrito (espaço pessoal), o qual se caracteriza pelo espaço em que a pessoa pode exercer controle sobre outros corpos e objetos. Esse aspecto é pré-requisito para a formação de conceitos como controle e posse.

\footnotetext{
${ }^{43}$ No original:

OBJECT TRANSFER

TRANSFER IS MOVEMENT FROM THE AGENT TO THE RECIPIENT

- Persons are locations

- Changes are movements

TRANSFER IS FORCED MOVEMENT

- Causes are forces

- Causation is forced movement

TRANSFER IS LOSS AND AQUISITION OF PHYSICAL CONTROL

- To control is to have in one's hand

- Loss and aquisition of control is changing hands
} 
A submetáfora Mudanças são movimentos permite conceituar a mudança como sendo um movimento produzido entre dois pontos no espaço que pode se referir a um espaço circunscrito. As mudanças não são apenas físicas - Lakoff e Johnson (1999 apud HUELVA UNTERNBÄUMEN, 2015) também consideram que mudanças no estado psicológico podem ser movimentos, o que explicaria o uso de verbos e preposições que originalmente são utilizados em expressões de mudança física e passam a ser igualmente utilizados com as que denotam mudança de estado, como em I came out of my depression 'Eu saí da minha depressão'.

A metáfora complexa Transferência é movimento forçado é composta pelas metáforas primárias Causas são forças e Causação é movimento forçado. Ambas as metáforas são essenciais para a estrutura conceitual humana, pois ajudam a construir os conceitos de causa e de causação. Huelva Unternbäumen (2015) argumenta que a estrutura conceitual dessas duas metáforas primárias pressupõe que toda força implica interação entre duas ou mais entidades, e que toda força tem um vetor, o que significa dizer que o exercício de força necessariamente refere-se ao movimento de uma entidade no espaço. Por exemplo, o movimento sofrido por uma entidade em uma construção de causação abstrata, como Tus actitudes me llevan a la locura 'Tuas atitudes me levam à loucura', refere-se a uma mudança de estado, visto que mudanças são conceitualizadas como movimento.

A terceira metáfora complexa Transferência é perda e aquisição de controle físico, basicamente, refere-se ao fato de que, no processo de transferência, o agente da transferência perde o controle do objeto material (no caso de transferências prototípicas), e o receptor passa a ter o controle do objeto (cf. (28b), repetido em (30a)). O controle, conceitualizado pela metáfora primária Controlar é ter nas mãos de um, reforça a ideia de que o controle (físico) é algo que pode ser manipulado. Entretanto, há, também, transferências abstratas, nas quais não há a transferência de objetos físicos, como, por exemplo, quando há a transferência de posse legal do objeto, ou seja, há a transferência de controle, mas não há a transferência do objeto (cf. (28c), repetido em (30b) abaixo).

(30) a. Eu dou esta garrafa para o senhor João.

b. O vizinho deu o lote para o filho dele.

(HUELVA UNTERNBÄUMEN, 2015, p.71) 
Huelva Unternbäumen (2015) analisa, além da categoria semântica de transferência de objeto (físico ou abstrato), a categoria de transferência de ação, uma vez que, segundo o autor, a conceitualização da transferência de ação, que é mais abstrata, ocorre a partir do conhecimento de contextos de transferência de objeto, que é mais concreta, e ambas as categorias são codificadas, em muitas línguas, do mesmo modo, utilizando construções bitransitivas. Na transferência de ação, em vez da transferência de um objeto físico, há ou a transferência do resultado de uma ação física, por exemplo, a transferência de 'um beijo' e de 'um sorriso', que são, respectivamente, o resultado das ações de 'beijar' e de 'sorrir' (cf. (31a) e (31b)), ou a transferência do resultado uma ação verbal, como em (31c), em que 'conselho' é o resultado a ação verbal 'aconselhar'.

(31) a. Sie gab mir einen Kuss. (Alemão)

'Ela me deu um beijo'

b. Ela deu um sorriso para o peão.

c. Et donaré un consell [...]. (Catalão)

'Vou te dar um conselho'

(HUELVA UNTERNBÄUMEN, 2015, p. 88)

Em um primeiro momento, a transferência de ação parece incluir os predicados psicológicos, pois, ao considerarmos a construção perifrástica 'João deu um susto nas crianças', parece haver a transferência do resultado de uma ação, em que 'um susto' resulta da ação de 'assustar'. Todavia, consideramos que 'dar um susto', nesse contexto, refere-se a uma leitura física desse predicado, e não a uma leitura psicológica, ou seja, o nome 'susto' não é um resultado psicológico, mas é um resultado de uma ação física. Na transferência de ação física, o resultado transferido sempre provém de uma mesma ação física prototípica, por exemplo, o beijo sempre é o resultado da ação física 'beijar', assim como o 'conselho' é sempre o resultado da ação verbal 'aconselhar'. Já com os predicados psicológicos, em uma sentença como 'O filho deu muita preocupação para a mãe', a 'preocupação' não é resultado de uma ação específica, visto que 'preocupar' não é uma ação física, nem uma ação verbal, sendo, na realidade, resultado de uma eventualidade anterior. Com essas observações, acreditamos que, diferentemente do resultado de ações física e verbal, a 'preocupação' ou o 'susto', em uma leitura psicológica', não são o resultado de uma ação particular, assim como não podem ser transferidos. Em resumo, as construções com predicados psicológicos não são 
uma categoria semântica de transferência de ação. Quanto ao tipo de transferência de objeto, é fácil afirmarmos que os verbos psicológicos não integram essa classe semântica, pois eles não possuem um objeto material que possa ser transferido fisicamente ou abstratamente.

O trabalho de Huelva Unternbäumen (2015) desenvolve uma análise detalhada sobre como se dá o processo de integração metafórica para a formação do polo semântico de transferência de objeto, tanto para as construções gramaticais prototípicas de transferência quanto para as diferentes possibilidades de transferências abstratas. Entretanto, pelo fato de, como mencionado anteriormente, as construções psicológicas não representarem uma construção de transferência, não apresentaremos essa parte do trabalho do autor.

Por mais que nosso objeto de estudo dessa dissertação não se enquadre semanticamente à classe de transferência, a pesquisa desenvolvida por Huelva Unternbäumen (2015) nos permite fazer diferentes correlações com esse objeto. ${ }^{44}$ Primeiramente, podemos relacionar os predicados psicológicos ao tipo de construção para o qual o autor desenvolve uma rede metafórica, a construção bitransitiva, que se assemelha ao tipo de construção que temos nas perífrases psicológicas causativas.

Outro ponto importante é o fato de as metáforas que compõem o polo semântico de transferência serem metáforas relevantes para a caracterização semântica dos predicados psicológicos. A metáfora primária Mudanças são movimentos, por exemplo, refere-se à propriedade de mudança de estado, a qual é uma propriedade sofrida pelo argumento Experienciador dos verbos psicológicos ExpObj. As submetáforas Causas são forças e causação é movimento forçado estão diretamente ligadas à propriedade de causação e de mudança de estado, visto que essa mudança, conceitualizada como movimento, ocorre devido a alguma causa, que pode ser abstrata ou não. Essa relação entre as duas propriedades é identificada nos predicados ExpObj, pois a mudança de estado sofrida pelo Experienciador é gerada por uma causa. Quanto às metáforas primárias Controlar é ter nas mãos de um e Perder ou adquirir controle é mudar de mãos, elas estão relacionadas ao fato de que qualquer transferência pressupõe uma mudança de controle (físico ou abstrato). Como os verbos psicológicos não se enquadram na categoria de transferência, eles também não sofrem uma

\footnotetext{
44 Huelva Unternbäumen (c.p.) apontou que, a partir do uso da metonímia para a caracterização do polo semântico de eventos complexos, os predicados psicológicos se enquadram na categoria semântica de transferência, mais especificamente na categoria de 'transferência de efeito pelo evento', na qual o 'efeito' representa o resultado da ação complexa expressa nos predicados psicológicos, além de ser metaforicamente conceitualizado como um objeto, o que permite a sua transferência. Ressaltamos, entretanto, que o trabalho do autor analisado nesta dissertação, Huelva Unternbäumen (2015), não nos permite caracterizar os predicados psicológicos como uma categoria de transferência, pois, como explanado, eles não possuem as propriedades das categorias de transferência de objeto e de transferência de ação.
} 
mudança de controle. Por outro lado, na literatura sobre os verbos psicológicos, a propriedade controle é definida por outro viés, no qual o controle está atrelado ao argumento sujeito de alguns predicados ExpObj que, tematicamente, é um agente e teria controle da ação expressa pelo verbo psicológico (CANÇADO, 1995).

Com relação à nossa investigação da hipótese de Landau (2010), observamos que Huelva Unternbäumen (2015) propõe que uma das metáforas responsáveis pela conceitualização dessas construções seja a metáfora primitiva Pessoas são locações. Essa metáfora corrobora, portanto, a proposta de que os Experienciadores são locativos, uma vez que o Experienciador é a pessoa conceitualizada metaforicamente como locação nos predicados psicológicos. Além do mais, o fato de o autor apontar a importância dessa metáfora na construção de conceitos de posse, reforça a nossa análise, a partir da proposta de Lakoff e Johnson (1999), de que parte das construções perifrásticas psicológicas tem sua conceitualização realizada por meio de metáforas eventivas de objeto, as quais exprimem uma conceitualização em termos de possessão (cf. (25) e (27)).

\subsection{SÍNTESE DO CAPÍTULO}

Neste capítulo, apresentamos três trabalhos que, em comum, desenvolvem propostas conceituais para os eventos linguísticos, a partir das relações semânticas espaciais de lugar. Jackendoff (1983) constrói uma teoria que parte da análise da estrutura conceitual de sintagmas preposicionados para o estabelecimento das relações temáticas espaciais. Essas relações servem de referência para a elaboração da Hipótese das Relações Temáticas, que propõe a generalização de que as relações espaciais, com adequada adaptação, estendem-se aos outros campos semânticos, e, portanto, podemos considerar que as relações espaciais também se estendem ao campo semântico dos predicados psicológicos.

As pesquisas desenvolvidas tanto por Lakoff e Johnson (1999) quanto por Huelva Unternbäumen (2015) pautam-se no arcabouço teórico da Linguística Cognitiva, responsável por propor que a conceitualização dos eventos é realizada de forma metafórica, sendo a metáfora espacial a grande responsável por esse processo. Entretanto, além da metáfora locativa, Lakoff e Johnson (1999) apontam que a conceitualização também é realizada a partir de metáforas de objeto, as quais conceitualizam a estrutura de um evento em termos de posse. Esses dois tipos de metáforas tornam-se bastante importantes para o nosso trabalho com as 
construções perifrásticas dos verbos psicológicos, pois, como mostramos neste capítulo, esses predicados podem ser conceitualizados a partir desses dois conjuntos metafóricos. O conceito de posse também é ressaltado pelo trabalho Huelva Unternbäumen (2015), que observa que esse conceito possui natureza locativa, por exemplo, um dos esquemas conceituais da expressão de posse é [Y em X], o qual utiliza o esquema espacial de localização para a sua formação.

É interessante observar que, mesmo possuindo mecanismos de conceitualização distintos - estrutura temática, para a Teoria Semântico-Conceitual de Jackendoff, e metáfora, para as pesquisas da Linguística Cognitiva -, todos os trabalhos têm, como ponto de partida, os elementos espaciais, por perceberem que eles estão presentes em diferentes categorias cognitivas, incluindo as não linguísticas. Estruturalmente, podemos destacar o papel determinante das preposições no processo de conceitualização, visto que Jackendoff (1983), para desenvolver a Hipótese das Relações Temáticas, parte da análise apurada de sintagmas preposicionados, e, na perspectiva da Linguística Cognitiva, são as preposições, juntamente com a seleção dos verbos, que determinam qual o tipo metafórico que conceitualiza um evento linguístico.

Nosso objetivo, neste capítulo, portanto, foi o de apresentar trabalhos de diferentes linhas teóricas que possuem uma análise conceitual locativa para as estruturas da língua, possibilitando, assim, fazer a relação com o pressuposto de Landau (2010) de que o argumento Experienciador dos predicados psicológicos é, cognitivamente, um locativo, para assim, podermos relacionar esse pressuposto, bem como os de outras propostas cognitivistas, à nossa análise das construções perifrásticas no capítulo subsequente. 


\section{CAPÍTULO 4}

\section{AS CONSTRUÇÕES PERIFRÁSTICAS DOS PREDICADOS PSICOLÓGICOS NO PORTUGUÊS BRASILEIRO}

Os predicados psicológicos são expressos, em diversas línguas, por meio de construções perifrásticas - verbo leve e nominalização -, como apontado por Arad (1998) e Landau (2010) (cf. seção 2.3 desta dissertação). Neste capítulo, apontamos generalizações descritivas para as construções perifrásticas dos predicados psicológicos no português brasileiro, com enfoque nos verbos leves, nas nominalizações e nas preposições que constituem esses predicados.

$\mathrm{Na}$ seção 4.1, levando em consideração a classificação de Cançado (1995) para os verbos psicológicos, descrevemos a formação das perífrases dos predicados ExpSuj e das construções ExpObj. Na seção 4.2, argumentamos, seguindo Fábregas; Marín; McNally (2012), que as nominalizações psicológicas do português são estativas e, na seção seguinte, 4.3, investigamos, tomando como base os trabalhos de Scher (2004) e de Gonçalves et al. (2010), se os verbos leves das perífrases psicológicas no português possuem propriedades predicadoras e, consequentemente, formam um predicado complexo junto com as nominalizações. Na sequência (seção 4.4), a partir das evidências fornecidas pelos verbos leves, nominalizações e preposições das construções perifrásticas, discutimos a hipótese locativa de Landau (2010) para os Experienciadores. E, na seção 4.5, adotando a proposta de Viñas-de-Puig (2014), consideramos que todos os predicados psicológicos no português brasileiro são formados a partir de uma estrutura básica estativa. Ao final, encerramos o capítulo com a síntese dos principais pontos resultantes da nossa análise para as construções perifrásticas no português brasileiro. 


\subsection{O CORPUS DE ANÁLISE}

Este trabalho dedica-se à pesquisa de construções perifrásticas - verbo leve e nominalização - dos predicados psicológicos no português brasileiro. Os dados utilizados para a análise foram, em sua maioria, coletados na Internet, além de, quando necessário, terem sido produzidos pela pesquisadora, levando em consideração o conhecimento linguístico de falante nativa de língua portuguesa. Como ponto de partida, utilizamos a seleção de verbos psicológicos disponível em Cançado (1995) e relacionamos cada verbo a sua respectiva nominalização, para depois coletarmos os dados referentes às construções perifrásticas. ${ }^{45} \mathrm{~A}$ nossa pesquisa das nominalizações foi realizada por meio da utilização das seguintes fontes: (i) Dicionário Aurélio Eletrônico Século XXI (AURÉLIO, 1999); (ii) Michaelis Dicionário Brasileiro da Língua Portuguesa (versão online), disponível em: http://michaelis.uol.com.br/moderno-portugues/; e (iii) Dicionário de Nomes Deverbais (versão online), disponível em: http://www.portaldalinguaportuguesa.org/.

Com relação aos dados coletados, em casos em que a construção perifrástica compõe um período composto (cf. (1a)), fizemos algumas adaptações para que o dado fosse uma oração absoluta (cf. (1b)), visando, assim, manter um padrão do corpus de análise. Além disso, sempre que possível, retiramos informações pessoais, como nomes de pessoas e empresas. A fonte dos dados que compõem este capítulo será fornecida no Anexo, de forma a não prejudicar a fluidez da leitura.

(1) a. A notícia foi dada pelo prefeito Jander Nunes Vidal (PSB) na semana passada em uma emissora de rádio, e causou preocupação entre os servidores.

b. A notícia causou preocupação entre os servidores.

Em muitas línguas, as construções perifrásticas são a única forma de expressão dos predicados psicológicos, ou, como no português brasileiro, elas são uma das configurações possíveis de expressão desses predicados. Os dados mostram que, em um mesmo contexto,

\footnotetext{
${ }^{45}$ Para reunir esses verbos, Cançado (1995) utilizou como fonte de pesquisa um dicionário de verbos (BORBA, 1990); um dicionário de língua portuguesa (AURÉLIO, 1975); exemplos da tese de doutorado Syntaxe des Verbes Psychologiques du Portugais (OLIVEIRA, 1979); além de exemplos fornecidos pela própria autora. Em princípio, esse corpus compreendia 360 verbos, mas a autora excluiu os verbos que apresentavam um argumento externo e outro preposicionado, como em "Maria gosta de João", devido ao fato de eles possuírem uma grade temática diferente dos outros 300 verbos, o que dificultaria o trabalho de comparação dos verbos. Essa seleção resultou no recorte de 300 verbos.
} 
pode-se encontrar a mesma informação sendo veiculada por uma perífrase (cf. (2a) e (3a)) e por uma construção com o verbo pleno correspondente (cf. (2b) e (3b)), o que nos possibilita assumir, assim como Arad (1998) e Landau (2010), que a interpretação semântica das construções perifrásticas contém as mesmas propriedades dos verbos plenos correspondentes.

(2) a. Regra de condomínio causa frustração.

b. O desconhecimento da lei de parcelamento de solo frustrou o sonho da casa própria de moradores e futuros moradores do empreendimento Terra Nova Bauru.

(3) a. A renovação de Licença de funcionamento de um grande hotel causou um estremecimento entre a prefeita e os vereadores do município.

b. Renovação de licença de hotel estremece relação de prefeita com vereadores.

Como vimos anteriormente (cf. Capítulo 2), a literatura sobre os verbos psicológicos não apresenta uma classificação uniforme para esses predicados. Especificamente com relação aos trabalhos para os verbos psicológicos no português brasileiro, Cançado (1995) divide esses verbos em 4 classes - uma referente aos verbos ExpSuj e outras três, a subclasses dos verbos ExpObj -, enquanto Naves (2005) apresenta uma classificação bipartite, considerando a possibilidade de esses verbos alternarem ou não, o que se reflete em uma divisão somente entre verbos ExpSuj e verbos ExpObj. Para a descrição das construções perifrásticas, adotamos, em princípio, a divisão de Cançado (1995), com o objetivo de verificar se as perífrases refletem as diferentes propriedades, apontadas pela autora, para as três subclasses de verbos ExpObj - classe de preocupar; classe de acalmar; e classe de animar.

\subsubsection{Os predicados Experienciador-Sujeito}

As construções perifrásticas dos predicados psicológicos ExpSuj, que, de acordo com Cançado (1995), compõem a classe de temer (classe 1), apresentam um padrão bastante consistente. $\mathrm{O}$ verbo leve utilizado para a formação desse tipo de estrutura, associado às mais diversas nominalizações psicológicas, é o verbo ter, e as preposições que introduzem o argumento interno do nome são, na maioria dos casos, 'por' e 'de', apresentando poucas ocorrências de outras preposições, como ilustram as sentenças a seguir: 
(4) a. Ele tem amor por João Pessoa.

b. O nosso povo tem grande apreço pela liberdade.

c. Nós temos o maior respeito pelo Brasil e suas leis.

d. Tenho admiração por trabalho, dedicação e competência.

e. Meu filho tem veneração por ele.

(5) a. Você tem inveja de mim.

b. Dunga não tem receio de demissão.

c. Clube tem ambição de ganhar uma prova europeia.

d. Ele não tinha temor dos homens.

e. Pessoas iradas têm ódio de si.

(6) a. A nossa sociedade tem rejeição à velhice.

b. Ele tem repúdio a mim e a classe médica.

c. Candidatos não têm respeito com o eleitor.

Em alguns casos, a perífrase é utilizada em uma leitura diferente da psicológica, por exemplo, as construções com a nominalização 'depreciação' aparecem apenas com sentido de desvalorização ou diminuição do valor financeiro:

(7) a. Empresa tem depreciação de $85 \%$.

b. Máquinas e equipamentos tem depreciação anual de $10 \%$.

A decomposição do predicado dos verbos ExpSuj mostra que esses verbos formam predicados de apenas uma eventualidade estativa, na qual o verbo representa o estado psicológico em que o Experienciador, argumento ' $\mathrm{x}$ ', se encontra. Adotamos a representação de estados de Rappaport e Levin (1998, p. 108) - [x < STATE $>$ - para analisar os verbos psicológicos ExpSuj:

(8) $[\mathrm{x}<$ STATE $>] \rightarrow[\mathrm{x}<\mathrm{TEME}>] ;[\mathrm{x}<\mathrm{AMA}>]$; $[\mathrm{x}<$ RESPEITA $>]$ 
Nas construções perifrásticas, o estado psicológico do Experienciador passa ser atribuído pela nominalização e pelo verbo leve ter, que é responsável por representar a relação de posse do estado pelo Experienciador, e, por isso, optamos por representá-lo na decomposição das perífrases:

\section{(9) $[\mathrm{x}$ TEM $<$ ESTADO $>$ ] $\rightarrow$ [x TEM $<$ TEMOR>]; [x TEM <AMOR>]; [x TEM $<$ RESPEITO $>]$}

Essa relação de posse presente nos predicados ExpSuj, expressa pelo verbo leve ter das construções perifrásticas, reforça a natureza locativa dos predicados psicológicos, visto que as noções de posse e de lugar estão interligadas (cf. ARAD, 1998; LAKOFF e JOHNSON, 1999; GONÇALVES et al., 2010; HUELVA UNTERNBÄUMEN, 2015), o que corrobora o pressuposto de Landau (2010) de que o Experienciador é um locus mental.

\subsubsection{Os predicados Experienciador-Objeto}

Os verbos ExpObj caracterizam-se por serem predicados causativos e de mudança de estado, no caso, causam a mudança de estado do Experienciador, que passa a estar em um estado psicológico específico. Consideramos que passar a um estado psicológico não é um processo instantâneo, pois o Experienciador sempre tem de perceber algo para atingir o estado resultante, o que caracteriza aspectualmente esses predicados como processos culminados, em que a culminação do processo é justamente a mudança de estado sofrida pelo Experienciador.

Pelo fato de grande parte das sentenças ter sido coletada em textos de gênero jornalístico, como a notícia, os dados apresentam algumas características particulares. Por exemplo, muitas construções perifrásticas possuem o verbo leve conjugado no tempo presente, o que, aparentemente, gera uma leitura estativa (cf. (10a) e (11a)). Observamos que esse tipo de construção é característico do gênero notícia, estando presente principalmente nos títulos dos textos, mas podemos reconhecer que o predicado não é de fato estativo, visto que, em alguns casos, o próprio texto fornece outra perífrase, em que a leitura estativa é anulada (cf. (10b) e (11b)):

(10) a. Morte de professor em acidente causa comoção e indignação em São Luís.

b. A morte dele causou comoção e indignação em milhares de pessoas. 
(11) a. Coleção da Arezzo com peles verdadeiras causa fúria de internautas e protetores de animais.

b. Sapatos, bolsas e echarpes com pele de raposa e coelho, lã de ovelha e couro natural foram usados e causaram a fúria de internautas e de protetores dos animais. $^{46}$

Outra característica presente nos dados dos predicados ExpObj refere-se ao fato de que, em muitas sentenças, o Experienciador não está foneticamente realizado:

(12) a. Sumiço de avião causa comoção $\varnothing$ na Indonésia.

b. Superlotação de estádio em Feira de Santana causa susto $\varnothing$ durante Bahia x Santos.

Mesmo não realizado foneticamente na sentença, o Experienciador é um argumento interno do nome que, assim como nos verbos, pode ser identificado pelo contexto. Por exemplo, pode-se dizer que o Experienciador da sentença (12a) é 'população', ou algo semanticamente equivalente, como 'moradores', e, em (12b), o argumento Experienciador é 'torcedores', pois pode ser identificado pela realização de uma outra perífrase no próprio texto: '[...] uma superlotação no local causou susto em torcedores'. Como este trabalho também procura estabelecer uma descrição das preposições utilizadas para a introdução desse argumento, a maior parte dos dados apresentados, ao longo deste capítulo, é constituída de perífrases em que o Experienciador é realizado.

A primeira, e maior, classe dos verbos ExpObj, proposta por Cançado (1995), é a de preocupar (classe 2). Os dados mostram que as construções perifrásticas dos predicados psicológicos dessa classe ocorrem, predominantemente, com o verbo leve causar. Quanto às preposições que introduzem o argumento Experienciador, prevalece o uso das preposições 'em' e 'a' (cf. (13) e (14)), mas também outras preposições como 'para', 'de' e 'entre' são constatadas, além da possibilidade de o Experienciador ser um pronome oblíquo (cf. (15)):

\footnotetext{
${ }^{46}$ A presença do artigo 'a' antes do nome 'fúria' também é uma evidência de que o predicado não é estativo, visto que ele contribui para eliminar a possível interpretação genérica do predicado, que está associada à leitura estativa.
} 
(13) a. A notícia causou preocupação nos usuários de internet banda larga no país.

b. A morte dele causou comoção e indignação em milhares de pessoas.

c. O final causou frustração em parte do público.

d. A mensagem causou abalo psicológico na estudante.

e. Esta forma de exercício da medicina causou desinteresse nos profissionais mais jovens.

f. A repercussão da entrevista do atual ministro da Casa Civil causou uma irritação no (nos membros do) seu partido.

g. Todo esse marketing causou deslumbramento no grande público.

h. Uma foto de Marte causou agitação na comunidade de astrólogos e ufologistas.

i. A notícia bombástica causou agito no mundo da música.

j. A decisão da semiestatal francesa de telefonia causou fúria no governo israelense.

(14) a. A pergunta sobre a censura causou aborrecimento ao assessor de imprensa.

b. Conduta da empresa causou aflição e traumas ao reclamante.

c. A expedição dessa ordem causou decepção a todos nós.

d. Relatos causaram encanto a muitos ouvintes do debate.

(15) a. A notícia causou preocupação para a comunidade escolar.

b. A péssima atuação da seleção causou decepção para os torcedores e também para muitos membros da imprensa esportiva.

c. O pronunciamento de Euclides Maciel causou preocupação dos parlamentares.

d. Medidas de racionamento causaram revolta entre pais e moradores.

e. As luzes, as bandeirinhas coloridas, as fantasias, as brincadeiras e, principalmente, a música e a dança me causaram tal encantamento.

De acordo com Cançado (1995), essa classe dos verbos ExpObj, diferentemente das outras duas, não permite que um argumento de papel temático Agente ocupe a posição de sujeito, sendo o papel temático de Causa o único possível. A amostra de dados acima favorece essa análise, visto que, em todas as sentenças, o sujeito é um argumento não agentivo, sendo uma Causa. Ressaltamos, entretanto, que, pelo fato de o levantamento de dados não ter sido 
exaustivo, não podemos afirmar que os sujeitos desses predicados sempre são caracterizados pela não agentividade.

Apesar de as perífrases da classe de preocupar serem formadas predominantemente pelo verbo leve causar, essas construções também podem ser compostas pelo verbo leve dar. Em um primeiro momento, imaginamos que a ocorrência desse verbo nessa classe não seria possível, pois, levando em consideração o seu verbo pleno homônimo, que seleciona, necessariamente, um argumento animado e agentivo para a posição de sujeito, tem-se um cenário em que as propriedades do sujeito do verbo pleno são opostas às propriedades do sujeito da perífrase. Todavia, como demonstram os dados abaixo, o verbo leve dar forma construções perifrásticas, mas, diferentemente, do verbo pleno, apresenta sujeitos não agentivos e não animados. ${ }^{47}$

(16) a. Nenhum doente me deu preocupação séria.

b. Esta linha da Tim já me deu muito aborrecimento.

c. Essa foto me deu muita aflição.

d. Outras pessoas só me deram decepção.

e. Barcelona deu esperança e frustração a brasileiro na Liga dos Campeões.

f. A vida deu a cada um de nós diversos encantos.

g. Ele deu preocupação para o adversário.

O verbo leve dar, mesmo apresentando propriedades semelhantes ao verbo leve causar, não possui a mesma produtividade, já que, como podemos observar, das dezesseis nominalizações que formam perífrases com causar, em (13), (14) e (15), apenas seis também participam de construções com o verbo dar (cf. 'preocupação', 'aborrecimento', 'decepção', 'frustração', 'aflição' e 'encanto'). Ainda que dar selecione, nessa classe, sujeitos com propriedades distintas dos sujeitos do verbo pleno, algumas propriedades se mantêm, por exemplo, a seleção das preposições 'a' e 'para' para introduzir o argumento preposicionado ou mesmo o uso de pronomes oblíquos, que são, tipicamente, características de construções bitransitivas com verbo pleno dar.

\footnotetext{
${ }^{47}$ É interessante observar que, em expressões idiomáticas formadas pelo verbo dar esvaziado do seu significado original, como em 'Maria deu pitaco na escolha da roupa' e 'João deu o bolo na Maria', os sujeitos dos predicados ainda preservam o traço de agentividade, diferentemente das perífrases dos predicados psicológicos, que podem ou não apresentar essa propriedade. Entretanto, em outros tipos de construção com nominalizações, a agentividade do sujeito não é observada, como no dado 'João deu uma comida de mosca', encontrado no trabalho de SCHER (2004). Esse tema merece maior investigação, o que deixaremos para trabalhos futuros.
} 
Outra subclasse dos predicados ExpObj proposta por Cançado (1995) é a de acalmar (classe 3) e representa a menor classe dos verbos ExpObj. Segundo a autora, a agentividade é responsável por definir as propriedades dos predicados dessa classe, o que, tematicamente, se reflete na possibilidade de o sujeito ser um Agente, além de uma Causa, como na classe 2. As construções perifrásticas referentes aos verbos dessa classe ocorrem apenas com o verbo leve dar, ou seja, diferentemente do atestado na classe de preocupar, os verbos dar e causar não concorrem, o que parece, portanto, refletir a natureza agentiva desses verbos, como proposto por Cançado (1995). Dessa forma, a seleção do sujeito desses predicados com o verbo leve dar preserva parcialmente propriedades do verbo pleno homônimo, pois, como uma das possibilidades, também permite sujeitos agentivos. Além disso, as preposições que introduzem o argumento Experienciador são as usadas nas construções bitransitivas de dar, 'a' e 'para', ou um pronome oblíquo representa esse argumento: ${ }^{48}$

(17) a. Poucas trocas de técnico deram calma ao Furacão (time de futebol).

b. Você me deu calma.

c. Vendas antecipadas do café conilon deram tranquilidade ao produtor no ES.

d. Conhecer o processo editorial deu serenidade para Vanessa.

e. Os policiais deram tranquilidade e segurança a todos os presentes.

Uma situação bastante recorrente na classe de acalmar é o fato de que muitos verbos só possuem perífrases com leituras físicas - como 'abrandar', 'reprimir', 'derrotar' e 'regenerar' -, ou seja, perde-se completamente o significado psicológico desses verbos, como ilustram as sentenças em (18).

(18) a. Crise causou abrandamento das emissões (de gases de efeito estufa).

b. O movimento ocupou o escritório da presidência, o que causou repressão policial.

c. Falta de preparação causou a derrota do Brasil.

\footnotetext{
${ }^{48} \mathrm{Na}$ contramão do tipo de perífrase encontrado para os verbos dessa classe, o verbo 'humilhar', por exemplo, representa uma exceção, pois possui construções perifrásticas apenas com o verbo leve causar, e, além das preposições utilizadas com dar, a preposição 'em' também aparece para introduzir o argumento Experienciador, não tendo sido encontradas, no corpus, sentenças com 'para':

(i) O fato causou vexame e humilhação à artista plástica.

(ii) A forma da dispensa lhe causou humilhação e abalo psicológico.

(iii) $\mathrm{O}$ tratado causou choque e humilhação na população.
} 
d. A injeção destas células por via muscular ou sistêmica causou regeneração dos músculos.

A última classe dos verbos ExpObj estabelecida por Cançado (1995) é a classe de animar (classe 4), caracterizada por apresentar propriedades tanto agentivas quanto não agentivas, isto é, possui características das classes 2 e 3, o que possibilita que o argumento na posição de sujeito seja uma Causa ou um Agente. Os dados das construções perifrásticas, entretanto, nos permitem apontar que esses predicados possuem, de maneira geral, as mesmas características dos predicados não agentivos da classe 2, visto que, predominantemente, o verbo leve utilizado nessas construções é o causar, e as preposições são 'em', 'a' e 'para'(cf. (19)).

(19) a. A foto causou animação nos fãs.

b. Essa mesma ideia causou animação e grandes expectativas para os fãs.

c. Um acidente em uma das atrações causou um verdadeiro susto na plateia e nos participantes.

d. Forte relâmpago causou susto à população.

e. A postura intelectual de Nina Rodrigues causou fascinação em Ortiz.

f. $\mathrm{O}$ fato sinistro e sanguinário causou fascínio à população.

g. A mensagem do Papa Francisco causou alegria em abundância aos participantes.

h. A grande movimentação de pessoas não causou intimidação aos bandidos.

i. A situação causou desencanto aos moradores da Rua Américo Brasiliense.

Assim como ocorre com os predicados da classe 2, na classe 4, algumas perífrases também podem ser formadas pelo verbo leve dar, como as construções com nominalização dos verbos plenos 'animar', 'assustar' e 'confortar', e, semelhante à classe 3, permitem uma leitura agentiva (cf. (20d,e)):

(20) a. Festa das Tradições deu grande animação a São João de Areias.

b. A exportação de 6,6 mil toneladas de amêndoas de cacau deu novo ânimo aos cacauicultores baianos.

c. Avião derrapa na pista em Belém e dá susto na delegação do São Raimundo. 
d. Pegadinha dá susto em aproveitadores de menores de idade.

e. Sua mãe sempre te deu conforto com um colo quentinho.

Com base nos dados das construções perifrásticas dos predicados psicológicos ExpObj no português brasileiro, podemos, portanto, estabelecer as seguintes generalizações descritivas quanto aos elementos que compõem esses predicados:

(i) o verbo leve causar é o verbo predominante nas perífrases dos predicados das classes de preocupar e de animar, sendo possível também, em alguns casos, o uso do verbo dar;

(ii) as perífrases do tipo de acalmar são formadas, em sua maioria, pelo verbo dar;

(iii) o verbo leve dar é utilizado em predicados tanto com leitura não agentiva quanto com interpretação agentiva;

(iv) as construções perifrásticas com verbo leve dar selecionam, majoritariamente, as preposições 'para' e 'a', para introduzirem o argumento preposicionado, além de apresentarem de forma recorrente um pronome oblíquo como o argumento Experienciador;

(v) além das preposições selecionadas pelo verbo leve dar, as perífrases com verbo causar apresentam a preposição 'em’ para introduzir o Experienciador.

Sabe-se que os verbos psicológicos ExpObj submetem-se ao processo de alternância sintática, na qual o argumento Experienciador passa a ocupar a função de sujeito, como mostram os dados a seguir:

(21) a. Cientista brasileiro se preocupou com a saúde e a qualidade de vida da população.

b. O povo se comoveu com sua saída.

c. Governo se decepcionou com amplitude da derrota de ontem.

d. Ele se fascinou com o pôr do sol.

Pelo fato de essas sentenças possuírem outra configuração sintática para seus argumentos, as construções perifrásticas desses predicados também são diferentes. Elas assemelham-se às perífrases dos verbos ExpSuj, pois são formadas pelo verbo leve ter: 
(22) a. Cientista brasileiro teve preocupação com a saúde e a qualidade de vida da população.

b. O povo teve comoção com sua saída.

c. Governo teve decepção com amplitude da derrota de ontem.

d. Ele teve fascínio com / pelo pôr do sol.

Com relação à decomposição de predicado das construções perifrásticas ExpObj, em que são representados os componentes semânticos primitivos das eventualidades que compõem o predicado, ela reflete a natureza bieventiva desses predicados, na qual a primeira eventualidade $[\mathrm{x}]$ representa o iniciador que causa a mudança de estado do argumento ' $\mathrm{y}$ ', que passa a estar um estado psicológico específico, como formalizado por Rappaport e Levin (1998, p. 108) para os processos culminados, conforme (23a). Para as construções perifrásticas, acrescentamos o primitivo TER, assim como nos predicados ExpSuj, para reforçar a ideia de posse que o verbo leve ter expressa:

(23) a. [x CAUSE [ BECOME [ y $<S T A T E>]]]$

b. [x CAUSA BECOME [y TER $\langle\text { ESTADO }]^{49}$

c. [x CAUSA BECOME [y TER <PREOCUPAÇÃO; ÂNIMO, CALMA>]

Com base nessa representação, pode-se notar que a segunda eventualidade, o estado, [Y TER <ESTADO>] - está presente em todos os predicados psicológicos, pois, nos verbos ExpSuj, ela é a única eventualidade do predicado, e, nos verbos ExpObj, ela é a eventualidade resultante do evento causador. Além disso, as estruturas alternantes dos verbos ExpObj (cf. (22)), que mapeiam o Experienciador como sujeito, passam a ser compostas apenas pela eventualidade estativa, perdendo, portanto, as propriedades causativas presentes na estrutura alternante em que o Experienciador ocupa a posição de objeto.

Como mencionamos anteriormente, o predicado psicológico estativo (predicado ExpSuj) está semanticamente relacionado à noção de posse e, por consequência, à noção de lugar. Pelo fato de constatarmos que o estado também está presente em todas as configurações

\footnotetext{
${ }^{49}$ Marcus Lunguinho (c.p.) propôs que, em vez do uso do primitivo TER na representação da estrutura de evento dos predicados ExpObj, um primitivo locativo como IN, retomando Jackendoff (1983), serviria para o nosso propósito de conceitualização locativa do Experienciador. Concordamos com Lunguinho, mas ressaltamos que a opção em manter o primitivo TER, responsável pela conceitualização dos predicados estativos ExpSuj, foi motivada com o objetivo de mostrar que os predicados ExpObj também possuem uma eventualidade estativa, que semanticamente expressa uma relação de posse / locativa.
} 
dos predicados psicológicos ExpObj, podemos apontar que todos os predicados psicológicos estão associados à semântica locativa, o que se caracteriza como propriedade semântica básica desses predicados, além de reforçar a hipótese de o argumento Experienciador ser uma locação, isto é, um locus mental (LANDAU, 2010).

\subsection{AS NOMINALIZAÇÕES}

As nominalizações presentes nas construções perifrásticas são as grandes responsáveis por manter a relação com os verbos psicológicos correspondentes. Isso porque uma "nominalização consiste num processo de associação lexical sistemática entre verbos e nomes" (BASÍLIO, 1980, p. 74 apud OLIVEIRA, 2014, p. 56) e, portanto, apresentam uma estrutura argumental, assim como os verbos. Na tradição gramatical, as nominalizações, cuja formação é realizada por meio do acréscimo de um sufixo ao verbo, são denominadas nomes deverbais. Com relação aos nomes deverbais psicológicos, podemos identificar que esses nomes são formados, predominantemente, a partir do acréscimo de três sufixos: (i) -ção; (ii) mento; e (iii) morfema zero: ${ }^{50}$

(24) a. Afligir $\rightarrow$ Aflição

b. Comover $\rightarrow$ Comoção

c. Frustrar $\rightarrow$ frustração

(25) a. Aborrecer $\rightarrow$ Aborrecimento

b. Deslumbrar $\rightarrow$ Deslumbramento

c. Estremecer $\rightarrow$ Estremecimento

(26) a. Animar $\rightarrow$ Ânimo

b. Desinteressar $\rightarrow$ Desinteresse

c. Respeitar $\rightarrow$ Respeito

\footnotetext{
${ }^{50}$ A formação de uma palavra por meio de um sufixo zero é conhecida na descrição tradicional como derivação regressiva, pois, nesses casos, a desinência verbal e a vogal temática do verbo são suprimidas, e uma vogal (-a, e, ou -o) é acrescida ao final da palavra, resultando em uma palavra menor que o verbo que deu origem a essa palavra (OLIVEIRA, 2014, p. 51).
} 
Além dos nomes deverbais, em alguns casos, o nome psicológico é que dá origem ao verbo, o qual recebe o nome de verbo denominal e se forma a partir da junção de uma vogal temática verbal e uma marca de flexão verbal a um nome, podendo, também, ser acrescido de um prefixo (BASSANI, 2009). Por exemplo, os verbos 'acalmar', 'atemorizar' e 'enciumar' são derivados dos nomes psicológicos 'calma', 'temor' e 'ciúme', respectivamente.

Muitas das nominalizações apresentam em sua definição no dicionário "ato ou efeito de X" - em que $X$ representa um verbo psicológico -, o que reforça a relação da nominalização com o verbo correspondente. Embora nem todos os nomes apresentem esse tipo de definição, acreditamos que os nomes psicológicos, como por exemplo 'aflição', que tem como definição "grande sofrimento; afligimento, agonia, angústia, desassossego, indisposição, inquietação", também carregam as propriedades relacionadas aos verbos dos quais foram derivados. ${ }^{51}$ Outra observação que podemos fazer a respeito dos nomes psicológicos é a de que alguns verbos possuem duas, ou mais, nominalizações, como, por exemplo, o verbo ‘encantar', que possui os nomes deverbais 'encantamento' e 'encanto' - um formado por derivação sufixal e outro, pelo morfema zero -, e ambos os nomes participam de construções perifrásticas (cf. (27)). Por outro lado, em alguns casos, mesmo quando o verbo apresenta duas nominalizações, apenas uma delas participa de perífrases (cf. (28)). Vale ressaltar, também, que muitos nomes psicológicos não participam de construções perifrásticas ou, pelo menos, não foram encontrados em nossa amostra de dados.

(27)a. A presença dos indígenas diante do estádio causou encantamento na maior parte dos turistas.

b. Relatos causaram encanto a muitos ouvintes do debate.

(28) a. Os policiais deram tranquilidade e segurança a todos os presentes.

b. *Os policiais deram tranquilização a todos os presentes.

As nominalizações, assim como os verbos, também possuem leituras aspectuais. Nas construções perifrásticas dos predicados psicológicos ExpSuj, as nominalizações são estativas, igual aos verbos plenos correspondentes, pois descrevem um estado que não se

\footnotetext{
${ }^{51}$ A definição para o nome 'aflição' foi retirada da versão digital do Michaelis Dicionário Brasileiro da Língua Portuguesa, disponível em: http://michaelis.uol.com.br/busca? $\mathrm{r}=0 \& \mathrm{f}=0 \& \mathrm{t}=0 \&$ palavra=afli\%C3\%A7ao.
} 
altera por um determinado período de tempo, e o verbo leve ter marca que o Experienciador possui um estado (cf. 'admiração' e ‘amor', em (29)).

(29) a. Tenho uma admiração especial pelo Brasil.

b. As duas pessoas têm amor por elas próprias.

Quanto à leitura aspectual das perífrases dos predicados ExpObj, consideramos que suas nominalizações também são estativas, diferenciando-se, assim, dos verbos dos quais elas derivam, uma vez que eles são classificados, aspectualmente, como processos culminados. Essa distinção de análise entre o verbo e a nominalização reflete a representação eventiva bipartite própria desses predicados, na qual o processo descrito na primeira eventualidade é o causador do estado descrito pelo nome psicológico.

(30) a. Polêmica do feriado no dia dos professores causou aborrecimento entre pais de alunos.

b. O tom da matéria causou incômodo aos usuários da rede.

Nesses predicados ExpObj, a primeira eventualidade ('Polêmica do feriado no dia das professores' e 'o tom da matéria') representa o processo que desencadeia o estado, isto é, a emoção resultante ('aborrecimento' e 'incômodo'), que representa a segunda eventualidade desses predicados complexos. Esses predicados também se submetem à alternância sintática, na qual o Experienciador passa a ocupar a posição de sujeito. Essa estrutura, assim como os predicados inerentemente ExpSuj (cf. (29)), possui apenas uma eventualidade, em que tanto o predicado quanto a nominalização recebem uma interpretação estativa:

(31) a. Os pais de alunos tiveram aborrecimento com a polêmica do feriado no dia dos professores.

b. Os usuários da rede tiveram incômodo com o tom da matéria.

Consideramos, portanto, que os nomes psicológicos nas construções perifrásticas são sempre estativos. Baseamos essa análise no trabalho de Fábregas; Marín; McNally (2012) sobre as propriedades aspectuais das nominalizações psicológicas no espanhol, no qual os autores argumentam que todos esses nomes são estativos, pois se referem a estados 
psicológicos. Para comprovar essa análise, eles apresentam diversos testes que distinguem nomes estativos de nomes de eventos dinâmicos, mostrando que as nominalizações derivadas dos verbos psicológicos comportam-se como estativos. Um dos diagnósticos, por exemplo, refere-se ao fato de que nomes psicológicos podem aparecer, naturalmente, em construções como 'um estado de N', em que N é um estado (cf. (32a)), enquanto os nomes eventivos não ocorrem nesse tipo de construção, como em (32b):

(32) a. Un estado de \{desesperación / obsesión / preocupación / sorpresa\}

'Um estado de \{desespero / obsessão / preocupação / surpresa\}'

b. *Un estado de \{rodaje / discusión $\}$

'*Um estado de \{filmagem / discussão\}'

(FÁBREGAS; MARÍN; McNALLY, 2012, p. 172)

Outro teste utilizado por Fábregas; Marín; McNally (2012) é o de que nomes psicológicos podem ser complementos da expressão 'dar mostras de', mas nomes que descrevem eventualidades dinâmicas não são compatíveis com essa expressão:

(33) a. Dio muestras de \{desesperación / preocupación / sorpresa\}

'Deu mostras de \{desespero / preocupação / surpresa\}'

b. *Dio muestras de \{rodaje / discusión\}

'*Deu mostras de \{filmagem / discussão\}'

(FÁBREGAS; MARÍN; McNALLY, 2012, p. 172)

Os autores mostram, ainda, que, diferentemente de nomes que denotam eventos, os nomes psicológicos não são compatíveis com predicados que selecionam eventos ou que produzem uma interpretação eventiva, por exemplo, os nomes psicológicos são inaceitáveis como sujeito de verbos que denotam propriedades de eventualidades dinâmicas, como 'acabar', 'terminar' e 'parar':

(34) a. Su \{rodaje / operación\} (ya) ha \{terminado / acabado / parado\}.

'Sua \{filmagem / operação\} (já) tinha \{terminado / acabado / parado\}.'

b. ${ }^{*} S u\{$ arrepentimiento / sobresalto $\}$ (ya) ha $\{$ terminado / acabado / parado\}.

‘*Seu $\{$ arrependimento / susto $\}$ (já) tinha \{terminado / acabado / parado $\}$.'

(FÁBREGAS; MARÍN; McNALLY, 2012, p. 170) 
Do mesmo modo, contrariamente aos nomes eventivos, os nomes psicológicos não podem ser complemento de 'durante', visto que o estado psicológico não representa um processo.

(35) a. Durante \{el rodaje / la operación $\}$, no hagan ruido.

'Durante a \{filmagem / operação\}, não façam barulho.'

b. *Durante su \{aburrimiento / desesperación\}, no hagan ruido.

‘*Durante seu \{aborrecimento / desespero\}, não façam barulho.’

(FÁBREGAS; MARÍN; McNALLY, 2012, p. 171)

Julgamos que esses testes, que mostram a estatividade dos nomes psicológicos, também são válidos para o português brasileiro, e, portanto, todas as nominalizações são estados. Enquanto os predicados ExpSuj possuem apenas uma eventualidade, que já é a própria emoção do Experienciador; o estado psicológico (nominalização) nos predicados ExpObj é o resultado de uma eventualidade anterior, de natureza causativa.

\subsection{OS VERBOS LEVES}

A partir dos dados apresentados das construções perifrásticas dos predicados psicológicos, pudemos estabelecer uma generalização descritiva dos verbos leves utilizados nessas estruturas: o verbo ter, nas construções em que o Experienciador é mapeado como sujeito (cf. (36a)), e os verbos causar, predominantemente, e dar, nos predicados ExpObj (cf. (36b) e (36c), respectivamente:

(36) a. Ela tem uma veneração pelo presidente muito grande.

b. Os excessos de chuvas na região de Bagé causaram preocupação para os produtores.

c. Estes anos de governação deram-lhe serenidade.

Ressaltamos, entretanto, que outros verbos leves, de forma menos produtiva, também constituem essas construções. Os predicados causativos (ExpObj), por exemplo, apresentam perífrases com os verbos gerar, provocar, colocar, levar e trazer, como ilustrado a seguir: 
(37) a. Adiamento das negociações nucleares gera decepção entre iranianos.

b. Era espacial gerou fascínio e medo.

c. Foto provocou comoção mundial.

d. O Itaú colocou medo nos mais fracos.

e. Um vazamento de amônia levou preocupação à comunidade searaense.

f. Geada trouxe preocupação para os produtores de hortaliças.

g. Uma falha de interpretação quanto ao horário de entrada na última prova trouxe aborrecimento a um atleta.

A questão suscitada pelos verbos leves refere-se à real natureza desses verbos, isto é, se eles são elementos meramente funcionais ou se contribuem semanticamente para a construção do predicado, ou seja, se também são elementos predicadores. Por essa razão, cabe-nos estabelecer o estatuto do verbo leve nas perífrases dos predicados psicológicos, tomando por base trabalhos que abordam essa questão em diferentes construções perifrásticas.

O verbo leve, originalmente, refere-se a um tipo de verbo tematicamente vazio, cuja função é a de fornecer informações gramaticais ao nome que possui informações semânticas, e com o qual ele forma um predicado complexo. Alguns trabalhos vêm mudando a perspectiva de análise desses verbos, mostrando que eles não são, exclusivamente, elementos possuidores de informações gramaticais. Entre esses trabalhos encontra-se o de Scher (2004), para construções com verbo leve no português brasileiro.

Scher (2004), a partir de uma análise minuciosa das construções com o verbo leve dar e nominalizações em -ada no português brasileiro, constata, em consonância com outros autores, como Diesing (1998, 2000 apud SCHER, 2004), que o verbo leve não contribui apenas com informações gramaticais, visto que as propriedades semânticas desses verbos são relevantes para a interpretação de todo o predicado.

Para comprovar essa análise, um dos argumentos a que a autora recorre é o de efeito diminutivizador que algumas estruturas com verbo leve dar e nominalização -ada geram, como em (38a), em contraposição à estrutura que não possui o verbo leve, e consequentemente, não apresenta a mesma leitura (38b):

(38) a. João deu uma caminhada / estudada / passeada.

b. João caminhou / estudou / passeou. 
(SCHER, 2004, p.104)

Deve-se frisar que essa interpretação só se torna possível mediante a construção do verbo leve dar com a nominalização em - $a d a$, pois tanto a relação dessa nominalização com um verbo leve diferente de dar (cf. (39)) quanto a relação de dar com uma nominalização de outra natureza (cf. (40)) não permitem que o efeito diminutivizador seja licenciado: ${ }^{52}$

(39) *João fez uma caminhada / um estudo / passeio.

(40) Deu uma explicada / *Deu uma explicação

(SCHER, 2004, p.104)

Outro argumento utilizado pela autora para comprovar a natureza predicativa do verbo leve dar nessas construções é o fato de ele impor restrições ao seu complemento, que pode ser um elemento verbal ou nominal, mas que, necessariamente, denota uma eventualidade que não apresenta os traços semânticos de estaticidade e de telicidade intrínseca:

(41) a. O João deu uma testada / *um teste no aparelho.

b. O João deu uma desenhada / *um desenho pra se distrair.

(SCHER, 2004, p.139)

Com relação às construções com verbos leves, Scher (2004, p. 94), afirma que:

As CVLs têm sua interpretação construída composicionalmente, ou seja, cada um de seus elementos, portador de informações relevantes para a interpretação do composto, participa ativamente da composição do significado resultante da combinação desses elementos.

Gonçalves et al. (2010), cujo trabalho tem por objetivo descrever e analisar propriedades de construções perifrásticas, formadas por verbos leves e nomes deverbais no português europeu, também argumentam que os verbos leves são predicados, visto que eles não são elementos meramente funcionais, isto é, não fornecem apenas informações

\footnotetext{
${ }^{52}$ Os exemplos (39) e (40) não são estruturas agramaticais no português do Brasil. Adicionamos a marcação de agramaticalidade nesses casos, pois, como apontado por Scher (2004), eles não permitem uma interpretação diminutivizada.
} 
gramaticais nem se comportam como verbos auxiliares. Essa análise está pautada em diferentes argumentos, entre os quais destaca-se o fato de os verbos leves poderem preservar a estrutura argumental do verbo pleno correspondente:

(42) a. O João deu uma gravata ao pai.

b. O João deu um abraço ao pai.

(43) a. O Pedro já teve dois peixes vermelhos.

b. O Pedro já teve uma conversa interessante com o professor.

(GONÇALVES et al., 2010, p. 452, grifo dos autores)

Os dados em (42) mostram que o verbo leve dar (cf. (42b)) preserva a estrutura argumental do verbo pleno (cf. (42a)), que possui três argumentos, e o verbo leve ter da sentença em (43b) é um predicado de dois lugares, assim como o seu verbo pleno correspondente em (43a).

Nas construções perifrásticas dos predicados psicológicos no português brasileiro, o verbo leve dar, presente em construções ExpObj, é um verbo de três lugares, assim como no português europeu, preservando, portanto, a grade argumental do verbo pleno correspondente:

(44) a. Sua saúde física também lhe deu preocupação. (Classe 2)

b. Gol deu tranquilidade ao Inter. (Classe 3)

c. Bronca do técnico após goleada para o Botafogo deu novo ânimo para o elenco. (Classe 4)

O verbo leve ter, utilizado nas perífrases referentes aos verbos ExpSuj, também apresenta uma estrutura argumental semelhante ao verbo pleno, com dois argumentos:

(45) a. Algumas pessoas têm amor por você.

b. Você tem inveja de mim.

Outro fator responsável pela análise dos verbos leves como um predicado, segundo os autores, é o fato de esses verbos também serem responsáveis pela seleção semântica do argumento externo. Essa propriedade diferencia os verbos leves dos verbos auxiliares, pois estes não contribuem com a seleção semântica argumental: 
(46) a. João tinha empurrado o carro que estava estacionado.

b. A chuva tinha empurrado o carro que estava estacionado.

(47) a. O João deu um empurrão ao carro que estava estacionado.

b. *A chuva deu um empurrão ao carro que estava estacionado.

(GONÇALVES et al., 2010, p. 453)

Nos dados em (46), o verbo pleno 'empurrar' é o responsável pela seleção do argumento externo, que pode ser especificado tanto com o traço [+animado] (cf.(46a)) quanto com [-animado] (cf.(46b)). Nessas construções, ter é um verbo auxiliar e, portanto, é exclusivamente responsável por carregar informações gramaticais, como tempo e número. Já na construção perifrástica, o argumento externo só pode ser especificado para o traço [+animado] (cf.(47a)), o que mostra que, mesmo tendo o nome 'empurrão', que deriva do verbo pleno, a seleção do argumento externo, de acordo com os autores, segue as propriedades de seleção semântica do verbo leve dar.

Com relação às perífrases psicológicas, notamos que, contrariamente ao atestado por Gonçalves et al. (2010), o argumento externo da construção perifrástica com verbo leve dar também pode ser especificado com traço [-animado], como nos exemplos a seguir:

(48) a. Essa foto me deu muita aflição. (Classe 2)

b. A vantagem no marcador dava calma à equipe. (Classe 3)

c. Vendas antecipadas do café conilon deram tranquilidade ao produtor no ES. (Classe 4)

As perífrases com verbo leve dar dos predicados psicológicos no português brasileiro, portanto, comportam-se de maneira distinta do português europeu, pois permitem um sujeito [-animado]. Essa propriedade também é responsável por marcar uma diferença entre as construções perifrásticas e as construções com o verbo pleno homônimo no português brasileiro, pois estas últimas só permitem um argumento [+animado] e agentivo na posição de sujeito, o que mostra que o verbo leve, juntamente com a nominalização, também interfere na seleção dos argumentos do predicado, no caso, a do argumento externo. 
Gonçalves et al. (2010) apontam, também, que os verbos leves preservam parte do significado e da estrutura dos verbos plenos correspondentes. O verbo dar, por exemplo, possui um argumento $y$, que está na posse de um argumento $x$ e é transferido para um argumento $z$, por meio de uma ação intencional de $x$. Nesse cenário, portanto, o verbo dar apresenta, como parte da sua estrutura semântica: um controlador, que também é uma causa; uma mudança de lugar; e uma transferência de y para $z$ (cf. DOWTY, 1979; BUTT e GEUDER, 2001 apud GONÇALVES et al., 2010), a qual, na visão dos autores, é preservada pelo verbo leve, como ilustrado em (49):

(49)a. (O João) $)_{x}$ deu (uma gravata) $)_{y}$ (ao pai) $)_{z}$.

b. (O João) $)_{x}$ deu (um abraço) $)_{y}$ (ao pai) $)_{z}$.

c. (O João $)_{x}$ deu (muitas preocupações) $)_{y}$ (ao pai) $)_{z}$.

(GONÇALVES et al., 2010, p. 453)

Estendendo essa estrutura semântica prototípica do verbo dar à sentença (49c) - que representa o tipo de construção perifrástica em análise neste trabalho -, atestamos que o argumento 'muitas preocupações' é possuído por 'João', o qual, por ser o controlador, transfere-o, intencionalmente, para o argumento 'o pai', resultando, assim, em uma mudança de lugar do elemento transferido. Acreditamos, entretanto, que essa análise para as construções perifrásticas dos predicados psicológicos no português brasileiro com verbo leve dar não é plenamente válida. Em primeiro lugar, como mencionamos anteriormente, em razão de o argumento externo dessas construções em português também admitir a especificação de traço [-animado] (cf. (48) e (50) abaixo), a presença de um controlador nesse tipo de estrutura passa a ser opcional, visto que o argumento externo só terá essa propriedade se ele for [+animado] e se ele agir intencionalmente, considerando que esse argumento nos predicados psicológicos também pode ser [+animado] e ser não intencional. Ainda com relação às propriedades do argumento externo dos predicados psicológicos, constatamos que ele, mesmo quando não se caracteriza por ser um controlador, sempre é uma causa, pois a primeira eventualidade desse tipo de predicado, representada pelo argumento externo, desencadeia o estado psicológico resultante de um argumento $z$.

(50) $(\text { Propostas })_{x}(\mathrm{me})_{z}$ deram (muita preocupação) $)_{y}$ 
Além disso, conforme apresentado na discussão do trabalho de Huelva Unternbäumen (2015) (cf. seção 3.3), consideramos que os predicados psicológicos não se caracterizam como um processo de transferência, pois não há nem a transferência de um objeto material (cf. 'uma gravata', em (49a)) nem a transferência do resultado de uma ação (cf. 'abraço', em (49b)).

Com base nessas considerações, podemos dizer que a evidência de que o verbo leve dar preserva parte do significado do verbo pleno correspondente é falha para as construções perifrásticas de verbos psicológicos no português brasileiro, o que, em princípio, enfraquece a ideia de que o verbo leve também tem propriedades predicadoras. Os dados no português brasileiro, contudo, nos permitem analisar esse verbo leve a partir de uma nova perspectiva. Como mostram as construções perifrásticas dos predicados psicológicas, o verbo leve dar pode ocorrer, de forma geral, no mesmo tipo de estrutura em que o verbo leve causar aparece, como ilustrado pela sentença em (51), que apresenta a mesma estrutura argumental e semântica da construção com o verbo leve dar, em (50).

(51) (O título do livro $)_{x}(\text { me })_{z}$ causou (preocupação) ${ }_{y}$.

Pelo fato de esses predicados ExpObj serem causativos, causar é, por excelência, o verbo formador dessas construções, e o verbo leve dar, nessas estruturas, assume grande parte das propriedades do verbo causativo, o que justifica o fato de esse verbo não apresentar propriedades semânticas do verbo pleno dar, como, por exemplo, a de não haver transferência de um argumento, além de explicar a possibilidade de esse verbo leve também selecionar argumentos externos com traço [-animado] (cf. (48)), uma vez que o verbo causar, pleno e leve, admite um argumento externo com esse traço. Nas construções perifrásticas do português europeu, Gonçalves et al. (2010) não apontam o verbo causar como um verbo leve formador das perífrases, mas analisam o verbo leve fazer (cf. (52)), o qual é um predicado causativo que implica mudança de estado do argumento benefactivo preposicionado, exclusivamente, sob a forma dativa (preposição 'a'), cujas propriedades também podemos encontrar no verbo leve causar (cf. (53a)):

(52) O Pedro fez muita aflição / impressão às crianças.

(GONÇALVES et al., 2010, p. 453) 
(53) a. A conduta da empresa causou aflição ao reclamante.

b. Essa foto me deu muita aflição.

A sentença em (52), que é uma construção perifrástica com predicado psicológico, é agramatical no português brasileiro, devido ao uso do verbo leve fazer. ${ }^{53}$ Percebemos, entretanto, que esse tipo de construção torna-se gramatical quando os verbos leves causar ou dar formam o predicado (cf. (53a) e (53b), respectivamente), o que mostra que, no português brasileiro, esses verbos leves são predicados causativos, que possuem um argumento, que sofre uma mudança de estado, no caso, o Experienciador ('reclamante' e 'me'). Essa situação reforça o fato de que o verbo leve dar, nesse tipo de construção, assume propriedades de um predicado causativo e deixa de exibir algumas propriedades do verbo pleno correspondente. Ressaltamos que, diferentemente das construções no português europeu com verbo leve fazer, no português brasileiro, o argumento preposicionado de predicados causativos não aparece apenas na forma dativa, podendo ser introduzido por outras preposições, como ilustrado abaixo:

(54) A elevação da barragem causou aflição na população.

Quanto às propriedades semânticas do verbo pleno ter (cf. (55a)), que também são manifestas pelo verbo leve, Gonçalves et al. (2010) o caracterizam como um verbo com dois argumentos, os quais expressam uma relação de posse/localização entre duas entidades. A única diferença entre o verbo pleno e o leve, segundo os autores, é que, na construção perifrástica, a preposição que introduz o sintagma preposicionado é determinada pela grade

\footnotetext{
${ }^{53}$ Em princípio, o verbo leve fazer não participa de construções perifrásticas dos predicados psicológicos no português brasileiro, como ilustra o dado em (52), no qual o uso desse verbo torna a sentença agramatical. Marcus Lunguinho (c.f), entretanto, nos apontou que há dados no português com o verbo leve fazer, como ilustrado a seguir:
}

(i) A impressão que eu tive é de que fizeram um susto a essa cidade.

Disponível em: http://wwmt-tv-martinsogaricgp.blogspot.com.br/2013/12/ariano-suassuna-compara-brasilia$\underline{\text { suica.html }}$

(ii) Fizeram um medo a ele.

Disponível em: http://blogdolucasnunes.com/?p=5037

Acreditamos que o verbo leve fazer participa apenas de construções com nominalizações específicas, como 'susto' e 'medo' (cf. (i) e (ii), respectivamente). Esse tema, porém, necessita maior investigação, o que deixaremos para pesquisas futuras. 
argumental do nome, isto é, em (55b), por exemplo, a preposição 'com' é selecionada pelo nome 'conversa', e não pelo verbo leve ter.

(55) a. O Pedro tem uma casa no campo.

b. O Pedro teve uma conversa importante com os pais.

(GONÇALVES et al., 2010, p. 453)

Essas propriedades arroladas pelos autores para o verbo ter também são compartilhadas pelas perífrases dos predicados psicológicos, uma vez que os dados em (56), por exemplo, mostram que as diferentes preposições utilizadas para introduzir o sintagma preposicionado - 'por' e 'de', em (56a) e (56b), respectivamente - são distintas da preposição usada na construção com verbo pleno (cf. (55a)), mostrando que são as nominalizações ('respeito' e 'receio') são as responsáveis por selecionar a preposição.

(56) a. As pessoas não tem muito respeito pelo próximo.

b. Professores têm receio de demissões.

A seleção da preposição que introduz o argumento Experienciador nos predicados com verbo leve causar não é realizada exclusivamente pela nominalização ou pelo verbo leve, visto que, como podemos estabelecer pelos dados em (57), a preposição na primeira construção é selecionada pelo nome 'revolta' (cf. a revolta de moradores com o comentário), enquanto em (57b) a preposição 'em' pertence à estrutura verbal (cf. X causa Y em Z). No caso de ter sido selecionada pelo nome, esperaríamos que a preposição fosse a mesma utilizada em (57a) (cf. a revolta dos pais com a creche). Essa não homogeneidade quanto à seleção das preposições mostra que o verbo leve e o nome compartilham propriedades predicadoras e que ambos participam da seleção e da projeção dos argumentos preposicionados do predicado.

(57) a. O comentário de uma juíza nas redes sociais causou revolta de moradores e vereadores de Peruíbe.

b. Creche de São Paulo causa revolta nos pais. 
Em suma, Gonçalves et al. (2010), assim como Scher (2004), argumentam que, devido ao fato de tanto os verbos leves quanto as nominalizações serem influentes na determinação das propriedades das construções perifrásticas, ambos formam um predicado complexo. Com base nas observações feitas em relação às perífrases dos predicados psicológicos no português brasileiro, verificamos que: (i) os verbos leves preservam a estrutura argumental dos verbos plenos correspondentes; (ii) os verbos leves interferem na seleção do argumento externo, como no caso do verbo dar; e (iii) os verbos leves também são responsáveis pela seleção da preposição. Com isso, concordando com Scher (2004) e Gonçalves et al. (2010), acreditamos que os verbos leves, juntamente com as nominalizações, constituem, portanto, predicados complexos nas construções perifrásticas dos predicados psicológicos no português brasileiro.

\subsection{EXPERIENCIADOR LOCATIVO}

Conforme vimos apresentando, Landau (2010) propõe que todo Experienciador é cognitivamente um lugar, mas apenas nos predicados em que esse argumento ocupa a posição de objeto, ele é gramaticalmente um locativo, isto é, um argumento oblíquo. O autor argumenta, ainda, que as construções perifrásticas dos predicados psicológicos representam uma evidência favorável a esse pressuposto, pois o Experienciador, nesse tipo de construção, é sempre oblíquo. No Capítulo 3, desenvolvemos a hipótese cognitiva do Experienciador, com base em trabalhos que partem das relações semânticas espaciais de lugar para conceitualizar os mais diversos eventos linguísticos, apontando o importante papel das preposições no estabelecimento da relação entre o campo semântico espacial e os outros diversos campos semânticos, em razão de elas terem um sentido prototípico referente à posição no espaço. Vimos que, nas perífrases dos predicados psicológicos ExpObj no português brasileiro, as principais preposições responsáveis por introduzir o Experienciador são 'em', 'para' e 'a', as quais, tipicamente, possuem como complemento sintagmas locativos (cf. 'casa' e 'universidade', em (58)), tais como os que ocorrem com os verbos de localização (cf. (58a)) e de movimento (cf. (58b)):

(58) a. João está em casa.

b. João foi para / à universidade. 
Outra preposição, menos recorrente mas registrada no nosso corpus de perífrases de verbos psicológicos do português é 'entre' (cf. (59)), que também possui um sentido locativo bastante característico, o que reforça a análise do Experienciador objeto como locus mental, além de codificá-lo gramaticalmente como um argumento oblíquo.

(59) a. Esta notícia causou preocupação geral entre os presentes.

b. A notícia causou decepção e indignação entre os produtores italianos.

c. Medidas de racionamento causaram revolta entre pais e moradores.

Ressaltamos que, diferentemente da hipótese de Landau (2010), que considera todos os Experienciadores cognitivamente locativos, como apresentado anteriormente, trabalhos de perspectivas teóricas distintas consideram que, em determinadas estruturas, em vez dos Experienciadores, os estados são contêineres/recipientes, isto é, um lugar: Lakoff e Johnson (1999), na Linguística Cognitiva, argumentam que o estado pode ser conceitualizado metaforicamente como um lugar, e Arad (1998), na Teoria Gerativa, considera que a interpretação locativa do estado é uma das interpretações possíveis dos predicados psicológicos. Essas análises ressaltam o papel das preposições na construção das estruturas linguísticas, pois, em uma sentença como 'João está em uma depressão profunda', a preposição é a responsável por caracterizar o estado psicológico 'depressão' como um local, no qual o Experienciador 'João' se encontra. Entretanto, com base nos dados das perífrases do português brasileiro, podemos constatar que o argumento Experienciador é sempre a locação que contém o estado psicológico, visto que ele é o argumento preposicionado.

Além das preposições, os verbos que compõem as construções perifrásticas também são fundamentais para determinar as propriedades semânticas da estrutura. As perífrases dos predicados ExpSuj, por exemplo, são constituídas pelo verbo leve ter, que, assim como o seu verbo pleno correspondente, está relacionado à semântica de posse, por sua vez estritamente ligada à noção de lugar (cf. ARAD, 1998; LAKOFF e JOHNSON, 1999; GONÇALVES et al., 2010; HUELVA UNTERNBÄUMEN, 2015), o que reforça a hipótese de que todos os Experienciadores são locativos. Salientamos que essa relação de posse também está presente nos predicados ExpObj, pois, como vimos anteriormente, esses predicados são bieventivos, em que a segunda eventualidade é estativa. Além disso, essa propriedade semântica da eventualidade estativa relacionada à posse, e, consequentemente, à noção de lugar, parece ser a caracterização semântica básica dos verbos ExpObj (e de todos os psicológicos), pois, na 
estrutura alternante intransitiva, o predicado passa a ter apenas uma eventualidade ('João se preocupou muito'), que é justamente o estado, o qual, quando expresso perifrasticamente, é construído pelo verbo leve ter ('João teve muita preocupação'), o que enfatiza a natureza locativa do Experienciador.

Assim como a presença do verbo leve ter dos predicados ExpSuj reforça a ideia locativa para os Experienciadores, o uso do verbo colocar nas construções perifrásticas dos predicados ExpObj (cf. (60)), mesmo que perifericamente, também é outra evidência que favorece essa análise, visto que o verbo pleno correspondente é, essencialmente, um verbo locativo.

(60)a. O Itaú colocou medo nos mais fracos.

b. Ela nunca me colocou medo.

\subsection{A ESTRUTURA SINTÁTICA DOS PREDICADOS PSICOLÓGICOS}

Com base na descrição das construções perifrásticas dos predicados psicológicos no português brasileiro, constatamos que, em todas as ocorrências desses predicados, tem-se uma eventualidade estativa: os predicados ExpSuj são constituídos por apenas uma eventualidade, que é justamente um estado; os predicados ExpObj transitivos caracterizam-se por serem bieventivos, em que a segunda eventualidade é o estado resultante do processo causativo descrito na primeira eventualidade; e a estrutura alternante intransitiva dos predicados ExObj deixa de apresentar a eventualidade causativa e passa a exibir apenas o estado. A partir desse cenário, em que o estado está sempre presente nos predicados psicológicos, e seguindo a proposta principal do trabalho de Viñas-de-Puig (2014), apresentada a seguir, consideramos que a estrutura estativa é a estrutura básica desses predicados no português brasileiro.

Em uma análise do comportamento dos predicados de Experienciador com verbo leve (PEVL) no castelhano e no catalão, Viñas-de-Puig (2014) propõe que todos os PEVL, assim como os predicados com verbo pleno, possuem uma estrutura básica, de interpretação estativa, como nas sentenças em (61):

(61) a. Me dan asco las ratas. (Castelhano)

'Os ratos me dão asco'. 


\section{b. Em fan por els comentaris racistes. (Catalão)}

'Los comentarios racistas me asustan.'

'Os comentários racistas me assustam'.

(VIÑAS-DE-PUIG, 2014, p. 167 e 171, grifo nosso)

As sentenças acima ilustram o padrão das construções estativas com verbo leve nessas línguas, que, segundo o autor, possuem o argumento Experienciador com Caso dativo (me e em fan) realizado na posição de sujeito. A partir dessa configuração dos argumentos e baseando-se no trabalho de Marín e Sánchez Marco (2012 apud VIÑAS-DE-PUIG, 2014) que propõe que o significado do verbo inclui o significado do nome, no caso, o significado estativo, Viñas-de-Puig (2014) estabelece a seguinte estrutura básica para os predicados psicológicos:

(62) Estrutura experienciadora básica

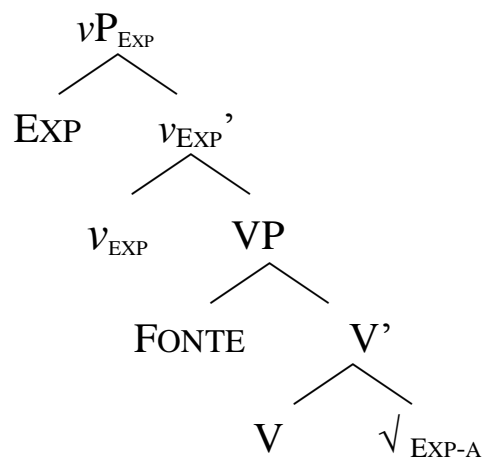

(VIÑAS-DE-PUIG, 2014, p. 170)

$\mathrm{Na}$ estrutura experienciadora básica, a Experiência $\left(\sqrt{E X P-A}_{\mathrm{A}}\right)$ é uma raiz que pode, ou não, se unir ao núcleo V, o argumento Fonte (ou Tema) ocupa a posição de especificador de $\mathrm{VP}$, e o Experienciador é introduzido pela projeção $v \mathrm{P}_{\text {Exp }}$. Em uma análise semelhante à de Arad (1998) (cf. seção 2.3.1), o autor propõe que a raiz Experiência pode aparecer incorporada ao núcleo $\mathrm{V}$, resultando no verbo lexical pleno (cf. (63)), ou pode aparecer de forma independente. Nesse último caso, a raiz $\bigvee_{\text {Exp-A }}$ comporta-se como um argumento independente (o nome psicológico) e tem-se a presença de um verbo leve na posição de núcleo V. No espanhol, o verbo leve utilizado nas construções perifrásticas é o 'dar' (cf. (64)). 
(63) Em molesten aquests comentaris. (Catalão)

'Me molestan estos comentarios.'

'Estes comentários me incomodam'

(64) Me da miedo la oscuridad. (Castelhano)

'A escuridão me dá medo'.

(VIÑAS-DE-PUIG, 2014, p. 172-173)

O autor aponta que predicados psicológicos podem apresentar uma variação entre leitura estativa e leitura eventiva, como em (65a) e (65b), respectivamente:

(65) a. Me asustan los comentarios racistas.

'Os comentários racistas me assustam.'

b. Esos niños me asustaron ayer.

'Essas crianças me assustaram ontem.'

(VIÑAS-DE-PUIG, 2014, P. 175)

A sentença eventiva (65b), diferentemente da estativa em (65a), indica uma mudança de estado do Experienciador, que tem origem em uma causa (Esos niños). Tais propriedades caracterizam uma leitura eventiva causativa, com mudança de estado. Viñas-de-Puig (2014) argumenta que, quando as construções possuem interpretação eventiva, elas são o resultado da adição de projeções funcionais à estrutura básica estativa, e essas projeções concordam com os traços eventivos que estão subcategorizados na raiz Experiência. Por exemplo, a estrutura de uma sentença causativa, como (65b), na proposta do autor, é representada pela inclusão das projeções funcionais ' $v \mathrm{P}$ Become $\mathrm{e}$ ' $v \mathrm{P}$ CAUS' acima da estrutura experienciadora básica (representada anteriormente em (62)), como ilustrado em (66): 
(66)

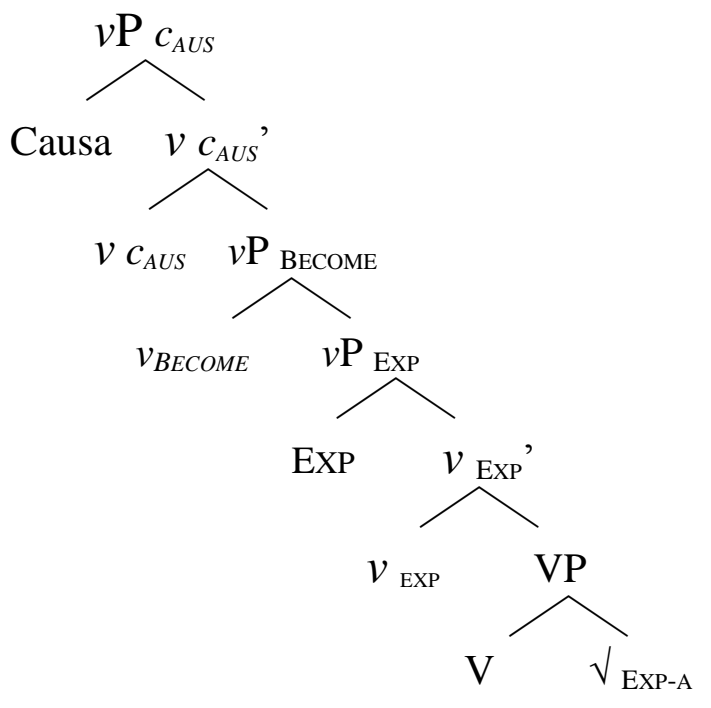

(VIÑAS-DE-PUIG, 2014, P. 181)

Segundo Viñas-de-Puig (2014), a projeção eventiva ' $v$ P Become' é responsável por introduzir uma estrutura incoativa, a qual podemos associar à estrutura alternante intransitiva dos predicados psicológicos ExpObj, como em 'João se preocupou', e só a partir da adição da projeção funcional ' $v \mathrm{P}$ CAUS' ligada à projeção ' $v \mathrm{P}$ BEсомE', que o predicado passa a ter um argumento Causa.

Ressaltamos que, diferentemente da proposta de Viñas-de-Puig (2014), que parte da constatação de que os predicados psicológicos ExpObj possibilitam as interpretações estativas e eventivas, nossa pesquisa não analisa as possíveis construções perifrásticas estativas dos predicados ExpObj no português brasileiro. Mesmo assim, pelo fato de considerarmos que todas as construções psicológicas têm uma eventualidade estativa, como mencionado anteriormente, adotamos a análise de que os predicadores psicológicos possuem uma estrutura estativa básica e que as estruturas eventivas são o resultado da adição de projeções funcionais, que são responsáveis por introduzir as interpretações causativa e de mudança de estado aos predicados psicológicos ExpObj. Outro aspecto relevante dessa estrutura para o nosso trabalho refere-se à proposta, semelhante à de Arad (1998), de o nome psicológico argumento Experiência na nomenclatura do autor - e o verbo pleno possuírem a mesma origem, a raiz $\bigvee_{\text {ExP-A}}$, pois, com essa configuração, as construções perifrásticas e as construções com verbo pleno possuem a mesma sintaxe, em termos das projeções argumentais, o que corrobora a ideia de que os dois tipos de construção carregam as mesmas propriedades semânticas. 


\subsection{SÍNTESE DO CAPÍTULO}

Neste capítulo, apresentamos a nossa análise para as construções perifrásticas (verbo leve e nominalização) no português brasileiro. Primeiramente, mostramos os padrões encontrados para os elementos formadores das perífrases dos predicados ExpSuj e dos ExpObj, levando em consideração a divisão de classes proposta por Cançado (1995). Os dados de perífrases corroboram a ideia, corrente na literatura, de que os verbos ExpSuj formam uma classe homogênea, visto que as construções perifrásticas que são constituídas sistematicamente pelo verbo leve ter. A análise também foi ao encontro da proposta de subdivisão da classes dos predicados ExpObj em três (sub)classes. No nosso corpus, a classe de preocupar apresenta construções perifrásticas formadas, majoritariamente, pelo verbo leve causar, admitindo, também, em menor proporção, o verbo leve dar como formador de perífrases. As construções perifrásticas da classe de acalmar são formadas apenas pelo verbo leve dar, o que nos permite relacionar esse diagnóstico à análise de Cançado (1995), que considera que as propriedades dos verbos dessa classe são determinadas pela natureza agentiva, pois, por mais que dar, como verbo leve, não conserve as mesmas propriedades agentivas do verbo pleno correspondente, ele ainda carrega propriedades mais agentivas que o verbo leve causar. As perífrases da classe de animar assemelham-se às construções da classe de preocupar, visto que a ocorrência do verbo leve causar também é superior à do verbo dar, corroborando a ideia de que a classe de animar compartilha propriedades das classes de preocupar e de acalmar. Em princípio, o que diferencia as classes de animar e de preocupar é o fato de os predicados da classe de preocupar só participarem de construções com interpretação não agentiva, enquanto, para a classe de animar, ser possível obter sentenças com leitura agentiva. Todavia, a dimensão do corpus utilizado em nossa pesquisa, não nos permite fazer afirmações categóricas de que uma classe ou outra não possui, de forma alguma, certa propriedade. Além disso, a análise de outros aspectos, como os efeitos psicológicos, são essenciais para determinar, de forma precisa, quantas são as classes dos predicados psicológicos, o que, entretanto, foge do nosso objetivo neste trabalho, ficando como questão de pesquisa para trabalhos futuros.

Com relação às preposições, as construções com verbo leve dar são constituídas, em sua maioria, pelas preposições 'a' e 'para', e as perífrases com verbo leve causar, além das preposições selecionadas pelo verbo dar, apresentam, de forma significativa, a preposição 'em' para introduzir o argumento Experienciador. 
Discutimos, também, neste capítulo, a natureza aspectual das nominalizações psicológicas e, seguindo o trabalho de Fábregas; Marín; McNally (2012), concordamos que os nomes psicológicos das construções perifrásticas no português brasileiro são sempre estativos.

Quanto à hipótese de que o argumento Experienciador dos predicados ExpObj é gramaticalmente um locativo, ou seja, é codificado como um argumento oblíquo (LANDAU, 2010), as construções perifrásticas no português mostram que as principais preposições que introduzem esse argumento - 'em', 'para' e 'a' - reforçam a análise locativa para o Experienciador, visto que essas preposições introduzem argumentos canonicamente locativos, além de terem sido encontradas no corpus outras preposições, como 'entre', também locativa, participando das construções perifrásticas ExpObj. Outra característica que corrobora a hipótese de Landau (2010) é o fato de haver perífrases construídas com verbo leve essencialmente locativo, que é o caso do verbo colocar. Os elementos formadores das perífrases, portanto, favorecem a análise do Experienciador locativo nesse tipo de construção. Ressaltamos que nosso objeto de pesquisa neste trabalho é restrito às construções perifrásticas no português brasileiro, de forma que não temos subsídios para estender os resultados obtidos na análise das perífrases às construções com verbos plenos.

Por último, a partir da observação de que, de alguma forma, os predicados psicológicos são constituídos por uma eventualidade estativa, argumentamos, adotando Viñas-de-Puig (2014), que os predicados psicológicos possuem uma estrutura básica estativa, que, quando associada a projeções funcionais específicas, passa a ser uma estrutura de leitura eventiva. Pelo fato de o nosso objetivo neste trabalho não ser o de propor uma análise detalhada para a estrutura sintática das construções perifrásticas, apresentando como se daria a derivação dessas estruturas, nossa reflexão centrou-se apenas na estrutura do nível argumental desses predicados. 


\section{CONSIDERAÇÕES FINAIS}

Nesta dissertação, analisamos as construções perifrásticas dos predicados psicológicos no português brasileiro, tendo por objetivo principal investigar se essas construções corroboram a hipótese de que o argumento Experienciador é cognitivamente um locativo, e se há evidências para afirmar que os Experienciadores-objeto são gramaticalmente oblíquos (LANDAU, 2010).

Para desenvolver o primeiro pressuposto, estabelecemos um diálogo com trabalhos de arcabouços teóricos diferentes da Teoria Gerativa, os quais, como ponto comum, partem das relações semânticas existentes no campo espacial e as estendem aos mais diversos campos semânticos. A Teoria Semântico-Conceitual de Jackendoff (1983) nos permitiu utilizar as relações temáticas presentes no campo espacial em outros campos semânticos, o que, aplicado aos predicados psicológicos, resulta na análise do Experienciador como estando associado ao papel de locação. Nos trabalhos de perspectiva da Linguística Cognitiva, Lakoff e Johnson (1999) e Huelva Unternbäumen (2015) argumentam que os eventos linguísticos são conceitualizados por meio de metáforas, e, nesse processo, constatamos que o Experienciador pode ser conceitualizado como um lugar. Além disso, analisando contrastivamente os dados de predicados psicológicos com os dados de predicados bitransitivos disponíveis na pesquisa de Huelva Unternbäumen (2015), argumentamos que as perífrases não se enquadram na categoria de transferência, e, como consequência, conseguimos caracterizar com maior clareza as construções com verbos psicológicos e redefinimos as propriedades das perífrases psicológicas formadas pelo verbo leve dar. Esses trabalhos de interface semântico-conceitual ressaltam, também, o papel dos verbos e das preposições na construção das relações semântico-conceituais do campo espacial, os quais são os elementos fundamentais em nossa análise na estrutura das perífrases psicológicas.

A investigação das construções perifrásticas no português brasileiro nos permitiu constatar que a formação das construções ExpSuj, que são estativas, exibem como padrão o verbo leve ter. Os predicados ExpObj, de forma geral, apresentam, como os seus principais formadores, os verbos leves causar e dar, os quais, por mais que possam aparecer como concorrentes em alguns contextos, possuem propriedades semânticas distintas. O verbo causar é utilizado, generalizadamente, em contextos não agentivos, nos predicados das classes de preocupar e de animar, as quais, segundo Cançado (1995) possuem propriedades 
determinadas pela leitura não agentiva. Na classe de preocupar, levando em consideração o nosso corpus, que não pretendeu ser exaustivo, o verbo dar só constitui predicados semanticamente, não agentivos, enquanto, na classe de animar, ele foi encontrado em algumas estruturas de interpretação agentiva. Na contramão dessas duas classes, tem-se a classe de acalmar, que possui, nas construções perifrásticas encontradas no corpus, apenas o verbo leve dar, tanto em estruturas agentivas quanto não agentivas. Por mais que essa classe apresente predicados agentivos e não agentivos, assim como a classe de animar, concordamos com o argumento de Cançado (1995) de que esses predicados têm as suas propriedades definidas pela agentividade, do que decorre a utilização do verbo leve dar, pois ele apresenta mais propriedades agentivas que o verbo causar. Destacamos, também, que, quando as construções perifrásticas apareceram em uma interpretação agentiva, apenas o verbo dar participou dessas estruturas. Por mais que nossa análise não tenha o alcance necessário para determinar com exatidão as propriedades semânticas de cada classe dos predicados ExpObj, nossos dados apontam algumas características importantes de cada classe, a partir do diagnóstico oferecido pelos verbos leves das estruturas.

Com relação às preposições que introduzem o argumento Experienciador nas construções perifrásticas - 'em', 'para', 'a' e 'entre', com menos frequência -, observamos que elas constituem evidência positiva para o pressuposto de Landau (2010), visto que todas elas são preposições semanticamente locativas.

Considerando a relação entre a semântica de posse e a de locação, apontada por diversos trabalhos, em diferentes perspectivas teóricas (cf. ARAD, 1998; LAKOFF e JOHNSON, 1999; GONÇALVES et al., 2010; HUELVA UNTERNBÄUMEN, 2015), pudemos estabelecer que essa relação está presente em todos as construções com predicados psicológicos. A construção em que essa relação é mais evidente é a dos verbos ExpSuj, pois o verbo leve formador da perífrase é o ter, que, da mesma forma que o verbo pleno homônimo, manifesta, por excelência, a semântica de posse. Os predicados psicológicos ExpObj possuem uma eventualidade resultativa, que é justamente o estado possuído pelo Experienciador como resultado de um processo causativo. Ou seja, pelo fato de a relação de posse estar presente em todas as construções perifrásticas, a semântica locativa identificada nos diversos trabalhos para as relações de posse também fortalece o pressuposto de Landau (2010), que investigamos neste trabalho.

Por fim, estabelecemos, assim como Scher (2004) e Gonçalves et al., em seus respectivos trabalhos, que os verbos leves das construções perifrásticas no português 
brasileiro também são predicadores e formam um predicado complexo com os nomes psicológicos, uma vez que eles colaboram para a formação estrutural e argumental dos predicados de que participam, e não fornecem informações restritamente gramaticais. Diante desse quadro teórico e empírico, adotamos a proposta de estrutura de Viñas-de-Puig (2014), para as construções perifrásticas, que estabelece que os predicados psicológicos possuem uma estrutura básica estativa, à qual projeções funcionais que concordam com os traços eventivos presentes na raiz Experiência são adicionadas, dando origem à estrutura eventiva dos predicados ExpObj.

Com este trabalho, esperamos contribuir, de alguma forma, no âmbito da Teoria Gerativa e das outras perspectivas teóricas, com as quais dialogamos, para o estudo das construções perifrásticas dos predicados psicológicos no português brasileiro, bem como para a pesquisa sobre os predicados psicológicos em geral, e, em uma visão mais ampla, para a aproximação das categorias de análise que dialogam entre si nas diversas abordagens que se dedicam ao desenvolvimento de uma teoria da gramática das línguas naturais. 


\section{REFERÊNCIAS}

ARAD, M. VP-Structure and the Syntax-lexicon interface. Tese de Doutorado. London, University College London, 1998.

BASSANI, I. Formação e Interpretação dos Verbos Denominais no Português do Brasil. Dissertação de Mestrado. São Paulo: USP, 2009.

BELLETTI, A.; RIZZI, L. Psych-verbs and Theta-Theory. Natural Language and Linguistic Theory, 6, p. 291-352, 1988.

CANÇADO, M. Verbos Psicológicos: A Relevância dos Papéis Temáticos Vistos sob a Ótica de uma Semântica Representacional. Tese de Doutorado. Campinas: Unicamp-IEL, 1995.

CHOMSKY, N. Linguagem e mente: pensamentos atuais sobre antigos problemas. Brasília: Editora UnB, 1998.

CHOMSKY, N. O Programa Minimalista. (1995). Tradução de E. Raposo. Lisboa: Caminho, 1999.

CHOMSKY, N. Sobre natureza e linguagem. São Paulo: Martins Fontes, 2006.

CROFT, W. Case marking and the semantics of mental verbs. In: PUTEJOVSKY, J. (org.) Studies in Linguistics and Philosophy 49: Semantics and the Lexicon, London: Kluwer Academic Publishers, 1993.

FÁBREGAS, A,; MARÍN, R.; McNALLY, L. From psych verbs to nouns. In: DEMONTE, V.; McNALLY. L. (Org.). Telicity, change, and state: A cross-categorial view of Event structure . Oxford: Oxford University Press, p. 162-185, 2012.

GONÇALVES et al. Propriedades predicativas dos verbos leves: estrutura argumental e eventiva. In: Brito et al. (Org.). Textos selecionados do XXV Encontro da Associação Portuguesa de Linguística. Porto: APL, p. 449-464, 2010.

HUELVA UNTERNBÄUMEN, E. From primary metaphors to the complex semantic pole of grammatical constructions. In: Language and Cognition, 7, p. 68-97, 2015.

JACKENDOFF, R. Semantics and Cognition. Cambridge: MIT Press, 1983.

LAKOFF, G.; JOHNSON, M. (1980). Metáforas de la vida cotidiana. Tradução de Carmen G. Marín. Madri: Cátedra, 2002.

LAKOFF, G; JOHNSON, M. Philosophy in the flesh: the embodied mind and its challenge to western thought. Nova Iorque: Basic Books, 1999.

LANDAU, I. The locative syntax of experiencers (Linguistic Inquiry Monographs 53). Cambridge, MA: MIT Press, 2010. 
LEVIN, B. English verb classes and alternation: a preliminary investigation. Chicago: University of Chicago Press, 1993.

LEVIN, B.; RAPPAPORT, M. Argument Realization. Cambridge: Cambridge University Press, Cambridge, UK, 2005.

NAVES, R. Aspectos Sintáticos e Semânticos das Estruturas com Verbos Psicológicos. Dissertação de Mestrado. Brasília: UnB, 1998.

NAVES, R. Alternâncias Sintáticas: Questões e Perspectivas de Análise. Tese de Doutorado. Brasília: UnB, 2005.

OLIVEIRA, D. Nominalizações no português brasileiro: Estrutura argumental, formação e morfossintaxe. Tese de Doutorado. Brasília: Unb, 2014.

RAPPAPORT, M.; LEVIN, B. Building Verb Meanings. In: BUTT, M.; GEUDER, W. (Org.). The Projection of Arguments: Lexical and Compositional Factors. Stanford, CA: CSLI Publications, p. 97-134, 1998.

SCHER, A. As Construções com o Verbo Leve DAR e as Nominalizações em -ada no Português do Brasil. Tese de Doutorado. Campinas: UNICAMP, 2004.

VIÑAS-de-PUIG, R. Predicados psicológicos y estructuras com verbo ligero: del estado al evento. In: Revista de Linguística Teórica y Aplicada, 52 (2), Conceição, Chile: Universidad de Concepción: Facultad de Humanidades y Arte, p. 165-188, 2014. 


\begin{abstract}
ANEXO
Referências dos dados utilizados no capítulo 4:
\end{abstract}

- A notícia foi dada pelo prefeito Jander Nunes Vidal (PSB) na semana passada em uma emissora de rádio, e causou preocupação entre os servidores. (cf. (1a))

- A notícia causou preocupação entre os servidores. (cf. (1b))

Disponível em: http://jornalfato.com.br/2016/conteudo.asp?codigo=20048

- Regra de condomínio causa frustração. (cf. (2a))

- O desconhecimento da lei de parcelamento de solo frustrou o sonho da casa própria de moradores e futuros moradores do empreendimento Terra Nova Bauru. (cf. (2b))

Disponível em: http://www.jcnet.com.br/Politica/2012/02/regra-de-condominio-causa-frustracao.html

- A renovação de Licença de funcionamento de um grande hotel causou um estremecimento entre a prefeita e os vereadores do município. (cf. (3a))

- Renovação de licença de hotel estremece relação de prefeita com vereadores. (cf. (3b))

Disponível em: http://www.dgabc.com.br/Noticia/493455/candidatura-causa-crise-entre-primos-lauroe-marcos-michels?referencia=destaque-imagem-home

- Ele tem amor por João Pessoa. (cf. (4a))

Disponível em: http://www.maispb.com.br/76870/cartaxo-confirma-licenca-e-elogia-nonato-ele-temzelo-e-amor-por-joao-pessoa.html

- O nosso povo tem grande apreço pela liberdade. (cf. (4b))

Disponível em: http://expresso.sapo.pt/internacional/2016-04-22-Dilma-na-ONU-O-nosso-povo-temgrande-apreco-pela-liberdade.-Sabera-impedir-qualquer-retrocesso

- Nós temos o maior respeito pelo Brasil e suas leis. (cf. (4c))

Disponível em: http://www.tudocelular.com/curiosidade/noticias/n67965/Facebook-Prisao.html

- Tenho admiração por trabalho, dedicação e competência. (cf. (4d))

Disponível em: https://pt.wikiquote.org/wiki/Ayrton_Senna

- Meu filho tem veneração por ele. (cf. (4e))

Disponível

em:

https://books.google.com.br/books?id=Bv x5z13fD4C\&pg=PA455\&lpg=PA455\&dq=Meu+filho+tem +venera\%C3\%A7\%C3\%A3o+por+ele.\&source=bl\&ots=nzRTS8fAav\&sig=BgL5Aa_CywaTCvlt98Ic j4sz2U4\&hl=pt-

BR\&sa $=$ X\&ved $=0$ ahUKEwjqzKGy4470AhXGgZAKHX5cDWkQ6AEIHjAA\#v=onepage\&q=Meu\% 20filho\%20tem\%20venera\%C3\%A7\%C3\%A3o\%20por\%20ele.\&f=false

- Você tem inveja de mim. (cf. (5a))

Disponível em: http://pensador.uol.com.br/voce_tem_inveja_de_mim/

- Dunga não tem receio de demissão. (cf. (5b))

Disponível em: http://veja.abril.com.br/noticia/esporte/dunga-diz-nao-ter-receio-de-demissao-so-temo$\underline{\text { a-morte }}$ 
- Clube tem ambição de ganhar uma prova europeia. (cf. (5c))

Disponível em: http://www.maisfutebol.iol.pt/videos/532b5b9324acfadc706e6a1d/clube-temambicao-de-ganhar-uma-prova-europeia

- Ele não tinha temor dos homens. (cf. (5d))

Disponível em: http://www.wilsonporte.org/site/joao-batista-temor-de-deus-vs-temor-dos-homens/

- Pessoas iradas têm ódio de si. (cf. (5e))

Disponível em: http://www.otempo.com.br/capa/brasil/pessoas-iradas-t\%C3\%AAm-\%C3\%B3dio-de$\underline{\text { si- } 1.380143}$

- A nossa sociedade tem rejeição à velhice. (cf. (6a))

Disponível em: http://agenciabrasil.ebc.com.br/geral/noticia/2016-06/sociedade-tem-rejeicao-velhicediz-presidente-da-sociedade-de-geriatria

- Ele tem repúdio a mim e a classe médica. (cf. (6b))

Disponível em:

http://www.crmpb.cfm.org.br/index.php?option=com_content\&view=article\&id=21929:repudio-aclasse-medica $\&$ catid $=46$ : artigos $\&$ Itemid $=483$

- Candidatos não têm respeito com o eleitor. (cf. (6c))

Disponível em: http://televisao.uol.com.br/colunas/flavio-ricco/2014/09/01/candidatos-nao-temrespeito-com-o-eleitor.htm

- Empresa tem depreciação de $85 \%$. (cf. (7a))

Disponível em: http://prosiga.jusbrasil.com.br/noticias/297887000/acoes-petrobras-despencam-eempresa-tem-depreciacao-de-85-com-relacao-a-2008

- Máquinas e equipamentos tem depreciação anual de 10\%. (cf. (7b))

Disponível em: http://www.classecontabil.com.br/consultoria-gratuita/ver/66259

- Morte de professor em acidente causa comoção e indignação em São Luís. (cf. (10a))

- A morte dele causou comoção e indignação em milhares de pessoas. (cf. (10b))

Disponível em: http://minard.com.br/2016/04/morte-de-professor-em-acidente-causa-comocao-eindignacao-em-sao-luis/

- Coleção da Arezzo com peles verdadeiras causa fúria de internautas e protetores de animais. (cf. (11a))

- Sapatos, bolsas e echarpes com pele de raposa e coelho, lã de ovelha e couro natural foram usados e causaram a fúria de internautas e de protetores dos animais. (cf. (11b))

Disponível em: http://estilo.uol.com.br/moda/noticias/redacao/2011/04/18/colecao-da-arezzo-compeles-verdadeiras-causa-furia-de-internautas-e-protetores-de-animais.htm

- Sumiço de avião causa comoção Ø na Indonésia. (cf. (12a))

Disponível em: http://jovempan.uol.com.br/noticias/mundo/sumico-de-aviao-da-airasia-causacomocao-na-indonesia.html

- Superlotação de estádio em Feira de Santana causa susto $\varnothing$ durante Bahia x Santos. (cf. (12b))

Disponível em: http://espn.uol.com.br/noticia/414312_superlotacao-de-estadio-em-feira-de-santanacausa-susto-durante-bahia-X-santos

- A notícia causou preocupação nos usuários de internet banda larga no país. (cf. (13a)) 
Disponível em: http://www.kustermachado.adv.br/artigo-polemica-limitacao-de-dados-da-internetfixa-um-estudo-comparado-com-outros-paises/

- A morte dele causou comoção e indignação em milhares de pessoas. (cf. (13b))

Disponível em: http://minard.com.br/2016/04/morte-de-professor-em-acidente-causa-comocao-eindignacao-em-sao-luis/

- O final causou frustração em parte do público. (cf. (13c))

Disponível em: http://bandconquista.com.br/sem-final-ultimo-capitulo-de-os-dez-mandamentos-causafrustracao-e-gera-memes/

- A mensagem causou abalo psicológico na estudante. (cf. (13d))

Disponível em: http://www.dicio.com.br/abalo/

- Esta forma de exercício da medicina causou desinteresse nos profissionais mais jovens. (cf. (13e))

Disponível em: http://docplayer.com.br/13170672-Feliz-natal-e-um-2016-repleto-de-saude-sucesso-emuita-paz-entre-os-povos-tintim.html

- A repercussão da entrevista do atual ministro da Casa Civil causou uma irritação no (nos membros do) seu partido. (cf. (13f))

Disponível em: http://br.blastingnews.com/politica/2016/01/entrevista-de-jaques-wagner-causairritacao-e-mal-estar-entre-pt-e-governo-00720587.html

- Todo esse marketing causou deslumbramento no grande público. (cf. (13g))

Disponível em: http://data-limite-2019.blogspot.com.br/2016/03/por-que-grande-midia-blinda-tantoos.html

- Uma foto de Marte causou agitação na comunidade de astrólogos e ufologistas. (cf. (13h))

Disponível em: http://portaldoamazonas.com/figura-misteriosa-que-lembra-uma-mulher-aparece-emfoto-de-sonda-que-esta-em-marte

- A notícia bombástica causou agito no mundo da música. (cf. (13i))

Disponível em: http://www.jornaljovem.com.br/edicao14/prince.php

- A decisão da semiestatal francesa de telefonia causou fúria no governo israelense. (cf. (13j)) Disponível em: http://oglobo.globo.com/mundo/saida-de-empresa-francesa-irrita-israel-16355463

- A pergunta sobre a censura causou aborrecimento ao assessor de imprensa. (cf. (14a)) Disponível em: http://www.midianews.com.br/conteudo.php?sid=6\&cid=199906

- Conduta da empresa causou aflição e traumas ao reclamante. (cf. (14b))

Disponível em: http://www.jornaldaordem.com.br/noticia-ler/empregado-sera-indenizado-portransportar-valores-em-desacordo-lei/27090

- A expedição dessa ordem causou decepção a todos nós. (cf. (14c))

Disponível em:

https://books.google.com.br/books?id=_dqPBAAAQBAJ\&pg=PT277\&lpg=PT277\&dq=causou+dece p\%C3\%A7\%C3\%A3o\&source=bl\&ots=rCds8LQSFn\&sig=k1OD0txp NOlCLJPOlQvzpRm3PI\&hl= pt-

BR\&sa $=X \& v e d=0$ ahUKEwjYic sw9LNAhWLIpAKHeUeCGY4MhDoAQgbMAA\#v=onepage $\& q=\mathrm{c}$ ausou\%20decep\%C3\%A7\%C3\%A3o\&f=false

- Relatos causaram encanto a muitos ouvintes do debate. (cf. (14d)) 
Disponível em: http://teatroufsm.blogspot.com.br/2014/09/sobre-abertura-do-iv-seminario-da.html

- A notícia causou preocupação para a comunidade escolar. (cf. (15a))

Disponível em: http://www.gazeta670.com.br/web/noticia.php?id=14602\#.V3ZyWfkrLIU

- A péssima atuação da seleção causou decepção para os torcedores e também para muitos membros da imprensa esportiva. (cf. (15b))

Disponível em: http://torcedores.com/noticias/2015/06/jornalista-da-espn-detona-atuacao-horrorosado-brasil-nao-temos-time-sem-neymar

- O pronunciamento de Euclides Maciel causou preocupação dos parlamentares. (cf. (15c))

Disponível em: http://al-ro.jusbrasil.com.br/noticias/2582052/o-pronunciamento-de-euclides-macielcausou-preocupacao-dos-parlamentares-que-de-imediato-se-manifestaram-o-vice-lider-do-governono-poder-legislativo-david-chiquilito-pc-do-b-declarou-q

- Medidas de racionamento causaram revolta entre pais e moradores. (cf. (15d))

Disponível em: https://www.facebook.com/jornaloglobo/posts/886116134761400

- As luzes, as bandeirinhas coloridas, as fantasias, as brincadeiras e, principalmente, a música e a dança me causaram tal encantamento. (cf. (15e))

Disponível em: http://odia.ig.com.br/diversao/2015-07-14/joao-pimentel-o-circulo-emziguezague.html

- Nenhum doente me deu preocupação séria. (cf. (16a))

Disponível em:

https://books.google.com.br/books?id=ACLW6vkzJbkC\&pg=PA59\&lpg=PA59\&dq=deu+preocupa\% C3\%A7\%C3\%A3o\&source=bl\&ots=6R4VHB1S3f\&sig=4rJeyohqjnCZ6kduVhjCXSbZ0kQ\&hl=pt-

BR\&sa=X\&ved=0CCEQ6AEwAjgKahUKEwjYjfiMj fHAhUEJx4KHVFwCxY\#v=onepage\&q=deu \%20preocupa\%C3\%A7\%C3\%A3o\&f=false

- Esta linha da Tim já me deu muito aborrecimento. (cf. (16b))

Disponível em: http://www.reclameaqui.com.br/13759852/tim-celular/cancelamento-do-celular-planocontrole/

- Essa foto me deu muita aflição. (cf. (16c))

Disponível em: https://www.flickr.com/photos/125456435@N03/14680765845

- Outras pessoas só me deram decepção. (cf. (16d))

Disponível em:

https://books.google.com.br/books?id=X5VTBQAAQBAJ\&pg=PA17\&lpg=PA17\&dq=deram+decep \%C3\%A7\%C3\%A3o\&source=bl\&ots=BB_0m5IXc6\&sig=UEBPzFljX9wT5vmWLT50IL1Hl7E\&hl $=\mathrm{pt}-$

BR\&sa $=X \& v e d=0 a h U K E w j I m Z e d 4 a v N A h X S 15 A K H X g X C o 84 C h D o A Q h G M A c \# v=$ onepage $\& q=$ der am\%20decep\%C3\%A7\%C3\%A3o\&f=false

- Barcelona deu esperança e frustração a brasileiro na Liga dos Campeões. (cf. (16e))

Disponível em: http://esporte.uol.com.br/futebol/campeonatos/liga-dos-campeoes/ultimasnoticias/2016/03/24/barcelona-deu-esperanca-e-frustracao-a-brasileiro-na-liga-dos-campeoes.htm

- A vida deu a cada um de nós diversos encantos. (cf. (16f))

Disponível em: http://slideplayer.com.br/slide/1806662/

- Ele deu preocupação para o adversário. (cf. (16g)) 
Disponível em: $\quad$ http://globoesporte.globo.com/mg/blogs/especial-blog/torcedor-do-atletico$\underline{\text { mineiro/1.html }}$

- Poucas trocas de técnico deram calma ao Furacão (time de futebol). (cf. (17a))

Disponível

em:

http://www.parana-

online.com.br/editoria/esportes/news/636614/?noticia=POUCAS+TROCAS+DE+TECNICO+DERA

$\underline{\mathrm{M}+\mathrm{CALMA}+\mathrm{AO}+\mathrm{FURACAO}}$

- Vendas antecipadas do café conilon deram tranquilidade ao produtor no ES. (cf. (17c))

Disponível em: http://www.noticiasagricolas.com.br/videos/cafe/155479-vendas-antecipadas-doconilon-dao-tranquilidade-ao-produtor-no-es-que-no-inicio-da-colheita-evita-

concentracao.html\#.V2hYD_krLIV

- Conhecer o processo editorial deu serenidade para Vanessa. (cf. (17d))

Disponível em: http://cultura.estadao.com.br/noticias/literatura,por-editora--conta-propria-ou-com-aajuda-dos-amigos-esta-facil-publicar-um-livro,10000013164

- Os policiais deram tranquilidade e segurança a todos os presentes. (cf. (17e))

Disponível em: http://gazetadonorte.com/?p=124018

- O fato causou vexame e humilhação à artista plástica. (cf. (i), nota de rodapé 48)

Disponível em: http://www.tjma.jus.br/tj/visualiza/publicacao/402264

- A forma da dispensa lhe causou humilhação e abalo psicológico. (cf. (ii), nota de rodapé 48)

Disponível em:

http://www.jusbrasil.com.br/jurisprudencia/busca?q=HUMILHA\%C3\%87\%C3\%83O+E+ABALO+P

SICOL\%C3\%93GICO

- O tratado causou choque e humilhação na população. (cf. (iii), nota de rodapé 47)

Disponível em: https://pt.wikipedia.org/wiki/Tratado de Versalhes (1919)

- Crise causou abrandamento das emissões (de gases de efeito estufa). (cf. (18a))

Disponível em: http://noticias.sapo.pt/info/artigo/1111365

- O movimento ocupou o escritório da presidência, o que causou repressão policial. (cf. (18b))

Disponível em: http://saopaulosao.com.br/nossas-acoes/1637-as-vozes-da-multid\%C3\%A3o-quegrita-contra-a-cultura-do-estupro-em-s\%C3\%A3o-paulo.html\#

- Falta de preparação causou a derrota do Brasil. (cf. (18c))

Disponível em: http://videos.bol.uol.com.br/video/falta-de-preparacao-causou-a-derrota-do-brasilacredita-torcedor-04024C9A3460C4895326

- A injeção destas células por via muscular ou sistêmica causou regeneração dos músculos. (cf. (18d))

Disponível em: http://www.acadim.com.br/Noticias/NOTICIA-2008-01-20-A.html

- A foto causou animação nos fãs. (cf. (19a))

Disponível em: http://br.nacaodamusica.com/noticias/festival-monsters-of-rock-pode-ter-outra-edicaono-brasil-em-2015/

- Essa mesma ideia causou animação e grandes expectativas para os fãs. (cf. (19b))

Disponível em: http://wwwmundoblog-mundonet.blogspot.com.br/2015/09/por-que-pokemon-go-seraum-fracasso.html 
- Um acidente em uma das atrações causou um verdadeiro susto na plateia e nos participantes. (cf. (19c))

Disponível em: http://www.diariopotiguar.com.br/2015/06/acidente-em-mirage-circus-causasusto.html\#sthash.DobDuQDj.dpuf

- Forte relâmpago causou susto à população. (cf. (19d))

Disponível em: http://www.blogdosilverioalves.com/2015/03/forte-relampago-causou-sustopopulacao.html

- A postura intelectual de Nina Rodrigues causou fascinação em Ortiz. (cf. (19e))

1.pdf

Disponível em: http://www.abralic.org.br/eventos/cong2011/AnaisOnline/resumos/TC1082-

- O fato sinistro e sanguinário causou fascínio à população. (cf. (19f))

Disponível em:

https://books.google.com.br/books?id=wd3d2WfZMYkC\&pg=PA72\&lpg=PA72\&dq=causou+fasc\% C3\%ADnio\&source=bl\&ots=pwhJmcwuH0\&sig=tGJluk_QAkHnRGKIIX24fSsoJls\&hl=pt-

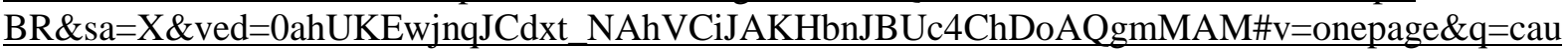
sou\%20fasc\%C3\%ADnio\&f=false

- A mensagem do Papa Francisco causou alegria em abundância aos participantes. (cf. (19g))

Disponível em: http://caritas.org.br/alegria-e-comocao-marcam-celebracao-de-abertura-do-13ointereclesial-das-cebs/24077

- A grande movimentação de pessoas não causou intimidação aos bandidos. (cf. (19h))

Disponível em: $\quad$ http://www.diariodolitoral.com.br/policia/dupla-assalta-loja-do-santos-fc-nogonzaga/46811/

- A situação causou desencanto aos moradores da Rua Américo Brasiliense. (cf. (19i))

Disponível em: $\quad$ http://www.ifolha.com.br/ler noticias.php?id j=12243\&titulo=Tapaburaco $\% 20 \mathrm{da} \% 20$ Prodem $\% 20 \mathrm{n} \% \mathrm{C} 3 \% \mathrm{~A} 3 \mathrm{o} \% 20$ resiste $\% 20 \mathrm{a} \% 20 \mathrm{um} \% 20 \mathrm{final} \% 20 \mathrm{de} \% 20$ semana

- Festa das Tradições deu grande animação a São João de Areias. (cf. (20a))

Disponível em: http://www.faroldanossaterra.net/2015/07/01/festa-das-tradicoes-deu-grandeanimacao-a-sao-joao-de-areias/

- A exportação de 6,6 mil toneladas de amêndoas de cacau deu novo ânimo aos cacauicultores baianos. (cf. (20b))

Disponível em: http://www.canalrural.com.br/noticias/agricultura/retomada-das-exportacoes-cacau$\underline{\text { novo-animo-aos-produtores-59771 }}$

- Avião derrapa na pista em Belém e dá susto na delegação do São Raimundo. (cf. (20c)) Disponível em: http://www.bvnews.com.br/noticia.php?intNotID=6586

- Pegadinha dá susto em aproveitadores de menores de idade. (cf. (20d))

Disponível em: http://www.areah.com.br/video/geral/video/67274/1/Pagina_1/pegadinha-da-susto-emaproveitadores-de-menores-de-idade.aspx

- Sua mãe sempre te deu conforto com um colo quentinho. (cf. (20e))

Disponível em: https://www.facebook.com/221908637925099/photos/pb.221908637925099.$\underline{2207520000.1462346047 . / 948923081890314 / \text { type }=3 \& \text { theater }}$

- Cientista brasileiro se preocupou com a saúde e a qualidade de vida da população. (cf. (21a))

Disponível em: http://www.pti.org.br/ec/muraldocientista/oswaldo-cruz 
- O povo se comoveu com sua saída. (cf. (21b))

Disponível em: http://www.portalweb7.com/2016/06/dilma-diz-tv-estrangeira-que-o-povo-se.html

- Governo se decepcionou com amplitude da derrota de ontem. (cf. (21c))

Disponível em: https://lucianoayan.com/2016/04/12/governo-se-decepcionou-com-amplitude-daderrota-de-ontem/

- Ele se fascinou com o pôr do sol. (cf. (21d))

Disponível em: http://sorisomail.com/partilha/349373.html

- A presença dos indígenas diante do estádio causou encantamento na maior parte dos turistas. (cf. (27a))

Disponível em: http://www.gentedeopiniao.com.br/noticia/amamos-futebol-como-qualquer-outrobrasileiro-reforcam-indigenas-em-partida-da-copa-em-sao-paulo/127115

- Relatos causaram encanto a muitos ouvintes do debate. (cf. (27b))

Disponível em: http://teatroufsm.blogspot.com.br/2014/09/sobre-abertura-do-iv-seminario-da.html

- Os policiais deram tranquilidade e segurança a todos os presentes. (cf. (28a))

Disponível em: http://gazetadonorte.com/?p=124018

- Tenho uma admiração especial pelo Brasil. (cf. (29a))

Disponível em: http://www.nossagente.net/empresario-americano-confessa-admiracao-pelo-brasil

- As duas pessoas têm amor por elas próprias. (cf. (29a))

Disponível em: http://www.significados.com.br/amor-verdadeiro/

- Polêmica do feriado no dia dos professores causou aborrecimento entre pais de alunos. (cf. (30a))

Disponível em: http://www.meionorte.com/videos/polemica-do-feriado-no-dia-das-professorescausou-aborrecimento-entre-pais-de-alunos-2225

- O tom da matéria causou incômodo aos usuários da rede. (cf. (30b))

Disponível em: http://www.opopular.com.br/editorias/magazine/bela-recatada-e-do-lar-entenda-afrase-que-invadiu-a-internet-1.1072697

- Ela tem uma veneração pelo presidente muito grande. (cf. (36a))

Disponível em: https://coturnonoturno.blogspot.com.br/2011/03/veneracao.html

- Os excessos de chuvas na região de Bagé causaram preocupação para os produtores. (cf. (36b))

Disponível em: http://www.jornalfolhadosul.com.br/noticia/2015/10/08/arroz-e-os-desafios-daproxima-safra

- Estes anos de governação deram-lhe serenidade. (cf. (36c))

Disponível em: https://www.noticiasaominuto.com/mundo/612171/jovem-morre-em-parque-aquaticodevido-a-ameba-que-come-o-cerebro

- Adiamento das negociações nucleares gera decepção entre iranianos. (cf. (37a))

Disponível em: http://noticias.r7.com/internacional/adiamento-das-negociacoes-nucleares-geradecepcao-entre-iranianos-25112014 
- Era espacial gerou fascínio e medo. (cf. (37b))

Disponível em: http://www.controversia.com.br/blog/5035

- Foto provocou comoção mundial. (cf. (37c))

Disponível em: $\quad$ http://www.opopular.com.br/editorias/mundo/charlie-hebdo-provocaindigna\% $3 \% \mathrm{~A} 7 \% \mathrm{C} 3 \% \mathrm{~A} 3 \mathrm{o}-\mathrm{com}$-caricaturas-de-menino-s\%C3\%ADrio-morto-1.946368

- O Itaú colocou medo nos mais fracos. (cf. (37d))

Disponível

em:

http://www.guiainvest.com.br/publicacao/default.aspx?publicacao=353922\&sigla=rumo3

- Um vazamento de amônia levou preocupação à comunidade searaense. (cf. (37e))

Disponível em: https://www.facebook.com/radiobelosmontes/posts/544657608973442

- Geada trouxe preocupação para os produtores de hortaliças. (cf. (37f))

Disponível em: http://catve.com/noticia/6/152962/geada-trouxe-preocupacao-para-os-produtores-dehortalicas

- Uma falha de interpretação quanto ao horário de entrada na última prova trouxe aborrecimento a um atleta. (cf. (37g))

Disponível em: https://www.cbtp.org.br/noticia/visualizar/893

- Sua saúde física também lhe deu preocupação. (cf. (44a))

Disponível em:

https://books.google.com.br/books?id=3zCdnAxdxggC\&pg=PA46\&lpg=PA46\&dq=deu+preocupa\%C 3\%A7\%C3\%A3o\&source=bl\&ots=yMjOXn33Yq\&sig=bSL2WP31PgdJGQxTcBqGpVnssKs\&hl=ptBR\&sa=X\&ved=0CB4Q6AEwATgKahUKEwjYjfiMj fHAhUEJx4KHVFwCxY\#v=onepage\&q=deu \%20preocupa\%C3\%A7\%C3\%A3o\&f=false

- Gol deu tranquilidade ao Inter. (cf. (44b))

Disponível em: http://www2.correiodopovo.com.br/Esportes/?Noticia=532255

- Bronca do técnico após goleada para o Botafogo deu novo ânimo para o elenco. (cf. (44c)) Disponível em:

http://www.pe.superesportes.com.br/app/18,98/2015/10/30/noticia nautico,39352/biteco-diz-quebronca-do-tecnico-apos-goleada-para-o-botafogo-deu-novo-animo-para-o-elenco.shtml

- Algumas pessoas têm amor por você. (cf. (45a))

Disponível em: http://pensador.uol.com.br/frase/Mjg4ODY2/

- Você tem inveja de mim. (cf. (45b))

Disponível em: http://pensador.uol.com.br/voce tem inveja de $\mathrm{mim} /$

- Essa foto me deu muita aflição. (cf. (48a))

Disponível em: https://www.flickr.com/photos/125456435@N03/14680765845

- A vantagem no marcador dava calma à equipe. (cf. (48b))

Disponível em: http://terceirotempo.bol.uol.com.br/noticias/fred-e-sobis-brilham-flu-bate-figueirensee-mantem-tabu-de-8-anos

- Vendas antecipadas do café conilon deram tranquilidade ao produtor no ES. (cf. (48c)) 
Disponível em: http://www.noticiasagricolas.com.br/videos/cafe/155479-vendas-antecipadas-doconilon-dao-tranquilidade-ao-produtor-no-es-que-no-inicio-da-colheita-evitaconcentracao.html\#.V2hYD_krLIV

- Propostas me deram muita preocupação. (cf. (50))

Disponível em: http://oglobo.globo.com/brasil/dilma-convoca-coletiva-para-criticar-marina-propostasme-deram-muita-preocupacao-13788480\#ixzz3qocDWqdY

- O título do livro me causou preocupação. (cf. (51))

Disponível em: http://blogtek.com.br/decisao-num-piscar-olhos/

- A conduta da empresa causou aflição ao reclamante. (cf. (53a))

Disponível em: http://www.jornaldaordem.com.br/noticia-ler/empregado-sera-indenizado-portransportar-valores-em-desacordo-lei/27090

- A elevação da barragem causou aflição na população. (cf. (54))

Disponível em: http://www.mundopiratini.com.br/2014/11/balneario-municipal-registra-elevacao.html

- As pessoas não tem muito respeito pelo próximo. (cf. (56a))

Disponível em: https://pensador.uol.com.br/frase/OTM0MDY3/

- Professores têm receio de demissões. (cf. (56b))

Disponível em: http://zh.clicrbs.com.br/rs/noticia/2016/05/desanimados-professores-tem-receio-dedemissoes-e-resistem-em-aderir-a-greve-5807595.html

- O comentário de uma juíza nas redes sociais causou revolta de moradores e vereadores de Peruíbe. (cf. (57a))

Disponível em: http://g1.globo.com/sp/santos-regiao/noticia/2016/06/juiza-chama-cidade-do-litoralde-sp-de-inferno-na-web-e-causa-revolta.html

- Creche de São Paulo causa revolta nos pais. (cf. (57b))

Disponível em: http://www.paisefilhos.com.br/crianca/creche-de-sao-paulo-causa-revolta-nos-pais-aopedir-que-as-meninas-estejam-com-cabelos-lisos/

- Esta notícia causou preocupação geral entre os presentes. (cf. (59a))

Disponível em: https://www.sinait.org.br/site/noticiaView/10022/em-reuniao-da-conatrae--sinaitreitera-denuncias-de-interferencia-na-fiscalizacao

- A notícia causou decepção e indignação entre os produtores italianos. (cf. (59b))

Disponível em: http://www.idasevinhas.com.br/2014/06/policia-italiana-apreende-falsos-vinhos.html

- Medidas de racionamento causaram revolta entre pais e moradores. (cf. (53c))

Disponível em: https://www.facebook.com/jornaloglobo/posts/886116134761400

- O Itaú colocou medo nos mais fracos. (cf. (60a))

Disponível em:

http://www.guiainvest.com.br/publicacao/default.aspx?publicacao=353922\&sigla=rumo3

- Ela nunca me colocou medo. (cf. (60b))

Disponível em: http://gazetaonline.globo.com/_conteudo/2009/11/divirta_se/noticias/565052-comoconcorrente-ela-nunca-me-colocou-medo--provoca-miss-gay-agredida.html 